Patricia Leonardelli

\title{
A memória como recriação do vivido um estudo da história do conceito de memória aplicado às artes performativas na perspectiva do depoimento pessoal
}

Tese apresentada como exigência parcial à obtenção do título de Doutor.

Curso de Pós- graduação em Artes Cênicas, Escola de Comunicações e Artes,

Universidade de São Paulo.

Orientador: Prof. Dr. Luiz Fernando

Ramos.

São Paulo

2008 


\section{RESUMO}

A tese A memória como recriação do vivido, um estudo da história do conceito de memória aplicado às artes performativas na perspectiva do depoimento pessoal pretende redimensionar o âmbito de atividade da memória humana a partir da análise de sua dinâmica de funcionamento dentro de diferentes processos de criação nas artes performativas, cujo produto denominamos depoimento pessoal. Desenvolveremos a hipótese de que todo trabalho da memória pressupõe, em maior ou menor grau, a recriação da experiência histórica original, e que os distintos tipos de depoimento são o resultado da combinação das forças operacionais específicas que pressionam a memória do artista em cada vivência de criação. 


\section{ABSTRACT}

The thesis The memory as re-cration of the lived facts, a study of the history of memory's concept applied to the performative arts in the perspective of the personal testimony intends to give a new measure to human memory's activities through the analysis of its' dynamic of work in the different process of creation in the performative arts, whose product we use to call personal testimony. We will sustain the hypothesis that every work of memory demands, in a higer or lower level, the re creation of the historical facts once experienced, and that the distinct kinds of testimony result from the combination of particular operational efforts, which pressure the artists' memory in a certain way during each process of creation. 


\section{SUMÁRIO}

RESUMO

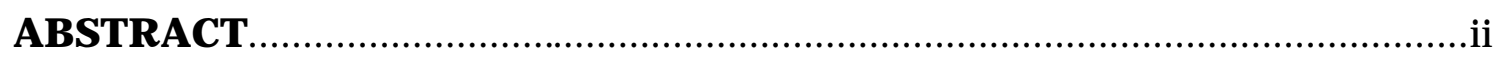

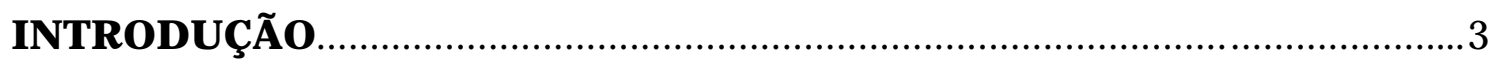

PARTE 1- A memória como atributo da mente e suas relações com as demais faculdades humanas............................................15

Capítulo I - Do inatismo platônico à Renascença..........................................................22

Capítulo II - A memória na transição para o pensamento científico e filosófico moderno

Capítulo III - Aspectos da Neurobiologia contemporânea: tipos de memórias, omapeamento cerebral como instrumento de análise da construção, evocação, preservação e destruição das memórias.

PARTE 2 - Da faculdade ao fluxo: a memória como recriação do vivido. .104

Capítulo I - A mnemo criação perceptiva em Bergson...........................................108

Capítulo II - Virtual e Atual, recordações de um Corpo sem Órgãos........................123

Capítulo III - A crítica da œnsciência imaginativa...............................................134

PARTE 3 - O depoimento pessoal: a memória criadora nas diferentes disposições dos relatos

Capítulo I - Memória e fabulação no treinamento interpretativo de Stanislavski.

Capítulo II - Os impulsos, ancestralidade e criação na cena depoimento do performer: Grotowski e o ato total.

Capítulo III - A memória nas performances de J oseph Beuys, Marina Abramovic e

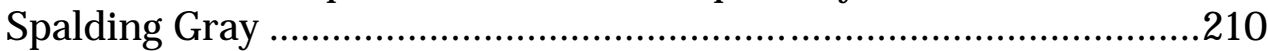

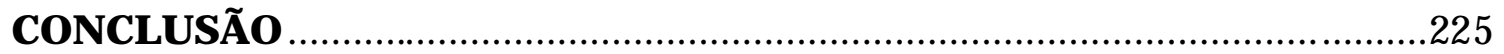

BIBLIOGRAFIA 


\section{INTRODUÇÃO}

"O tempo é o mágico de todas as traições" J oão Guimarães Rosa

A tese A memória como recriação do vivido, um estudo do conceito de memória aplicado às artes performativas na perspectiva do depoimento pessoal nasce de uma observação pessoal extensa e antiga sobre os fenômenos que envolvem a disposição dos conteúdos históricos do performer em diferentes processos de criação. O estatuto filosófico e estético da pós-modernidade ${ }^{1}$ provœa uma série de questionamentos sobre a construção do sujeito, a historicidade do corpo, a consistência ontológica da narrativa e dos testemunhos como agregadores culturais para formação das identidades coletivas, e outras questões subjacentes que impelem a uma revisão profunda da forma como o hamem relatou, selecionou e organizou sua experiência ao longo dos séculos.

No campo das artes performativas, inicialmente, as novas formas fragmentadas de disposição do discurso da cena sugeriam uma espécie de recusa à préformação de sentidos e à tomada de posicionamento ideológico sobre os materiais dispostos, efeito quelogo exigiu a revisão dos resultados e a assunção da des-estruturação como linguagem, pois, uma criação exposta em um tempo discorrido criará representações à revelia de seu autor de qualquer forma. Negar o movimento do tempo é fugir da responsabilidade de assumir a intencionalidade da criação, e essa fuga ficará registrada na história da obra.

\footnotetext{
${ }^{1}$ Para uma introdução ao pensamento sobre a pós-modernidade e suas estruturas organizacionais políticas, sociais e culturais, ver $O$ pós-moderno e A condição pós-moderna, de Jean-François Lyotard.
} 
Partindo dessa constatação, passamos a pensar sobre o tema que interessa a nossa arte, a arte do ator-performer, na condição pós-moderna, de onde chegamos imediatamente na memória como ferramenta e em sua utilização na criação performativa. Na performance, a relação do intérprete-criador com o tempo é profundamente caótica para os padrões com os quais costumamos organizá-lo no cotidiano. Se os processos de criação não permitem uma perspectiva cronológica do tempo, também não se pode trabalhá-los como uma abstração de todo relativa aos seus operadores processuais internos, inteiramente livre das arbitrariedades do psiquismo e da consciência.

No tempo da criação, o passado irrompe como a força que recupera e revela os subsídios pelos quais o sujeito se oferece aos estímulos do processo. Esses materiais são a fonte de seu depoimento pessoal, são o próprio sujeito transbordando da pele em ações, sons, palavras, e reconstruindo sua história pelas circunstâncias da ficção. Mas onde termina a suposta verdade como experiência originária e começa a fantasia da recriação do vivido? Quais processos permitem se construir um relato mais mimetizado ao real e quais outros assumem a fábula como máscara? Ou a fantasia como escudo para sublimar o irrepresentável, o traumatizado e oculto?

Essa problemática nos pareceu encantadora desde o início, e cresceu junto com a consciência de que sua solução demanda uma vida inteira de investigação e observação, e a resignação de que, ao final, provavelmente, não encontraremos respostas definitivas. Da mesma forma, em torno desta parece estar condensada boa parte das questões sobre o trabalho do performer das quais não podemos nos esquivar em nossa profissão. Como funcionam e se expressam os movimentos da 
nossa história nesse adensamento orgânico chamado corpo, é a pergunta-chave. De onde logo vêm outras igualmente complexas: por onde se desloca a imagem no corpo- mente? Quais os fatores de reverberação? No que implica a autenticidade do relato: na fidelidade ao testemunho da experiência ou na capacidade de recriação?

Nossa prática ofereceu algumas indicações iniciais, pois, ainda cremos que a reflexão deve partir inicialmente da vivência. Por mais curioso que possa parecer, o fato é que todos os processos de criação dos quais tomamos parte nos legaram uma só intuição, a partir da qual elaboramos nosso projeto de pesquisa: a retenção é apenas uma faceta pálida do complexo trabalho da memória.

Voltamos, então, à revisão dos principais pedagogos da arte da interpretação e a alguns artigos com depoimentos de processo de performers strictu sensu para verificar se haveria ali apontamentos semelhantes aos nossos, pelos quais poderíamos começar a sistematizar uma reflexão mais consistente, e assim sucedeu. As artes performativas, atividades de fronteira por natureza, oferecem os registros documentais por onde se pode iniciar a revisão do conceito de memória como retorno da experiência (e do sujeito, enquanto formado pela experiência) ao passado, até o desligamento completo do real; e sugerir a idéia de atualização do vivido pelo presente, pressuposto de nossa investigação.

A memória, quando trabalhada em função da construção do depoimento pessoal, e a disposição dos conteúdos históricos do performer para a criação, exigem um trânsito criativo, intenso e, por vezes, acelerado entre os conhecimentos apreendidos e em apreensão, a ponto de um se misturar de tal forma ao outro que já não se pode falar em núcleos fechados de experiência armazenada, mas em fluxo de contaminações. Eis porque a memória como faculdade que distribui o vivido em 
unidades factuais no tempo do movimento linear já não dá conta de explicar o funcionamento da mente humana em situação de criação.

O substrato teórico veio naturalmente ao nosso encontro quando determinamos o objeto de pesquisa, posto que somente pelo pensamento contemporâneo encontraríamos interlocutores que partilhassem de nossa perspectiva não- arborescente² de estudo e fornecessem o paradigma conceitual que justificasse nossa hipótese. O depoimento pessoal é construído pela memória criadora, e suas singularidades processuais atestam a riqueza de possibilidades que essa função nos oferece para reinventar a existência. Somente por que temos memória e porque ela é criadora e trabalha em conjunção com todas as demais faculdades - ou arrisquemos mais longe, não falemos mais em faculdades, senão em adensamentos mentais de funções em devir que criam o grande fluxo das ações humanas - é que a arte se tornou possível.

Criar vidas que não existem, construir existências paralelas, depoimentos pessoais fantásticos organizados e dispostos na forma de uma personagem tradicional, ou destroçar o ego e esquizofrenicamente reparti-lo em diversas personas com depoimentos distintos, pelos quais fala, por trás e junto, o artistacriador (como faz lindamente Spalding Gray, em suas cenas-depoimento dilacerantes sobre o suicídio da mãe na obra Rumstick Road), são maneiras diferentes de organizar o depoimento. Ou mais.

\footnotetext{
${ }^{2}$ Arborescência é um conceito-chave da terminologia deleuziana, uma forma de articular o pensamento binária e verticalizada, à qual ele opõe opensamento rizomático, horizontal, estruturado no plano das multiplicidades, estratos, segmentaridades, linhas de fuga e intensidades, agenciamentos maquínicos de diferentes tipos, etc. Para uma explicação mais completa sobre rizoma e arborescência, ver o texto Introdução: Rizoma, in Mil Platôs 1, pp. 11-38.
} 
É o próprio sujeito-artista que se desfaz e se reinventa na criação e estruturação do depoimento a cada apresentação. Mais do que em qualquer outra atividade humana, é o artista da cena que se põe em devir como profissão, se dilui e se reconta infinitamente cada vez que depõe para formar sua obra. Nosso esforço, a partir de agora, é de relacionar essa intuição que nos persegue ao estudo maior da evolução da memória nas principais tradições filosóficas e científicas para verificarmos se ela é algo mais que o resultado da nossa experiência particular, quem sabe, um ponto de partida pelo qual possamos formalizar uma reflexão que sirva de estímulo para outras abordagens sobre o tema.

Depoimento pessoal é uma expressão que se firmou já há alguns anos no abundante quadro de terminologias técnicas que se esforçam para definir os múltiplos mecanismos de criação do artista da cena contemporânea. A revisão que nos propusemos a fazer acerca das atribuições da memória, amparados pela filosofia pós-estruturalista e pelo pensamento bergsoniano, interfere diretamente na dimensão original de tal conceito, cuja reformulação torna-se, assim, objeto central de nossa tese.

Retomemos a definição já apresentada para depoimento pessoal: disposição dos conteúdos históricos do performer para criação. Em outras palavras, convencionamos chamar de depoimento pessoal à memória quando colocada a serviço especificamente da criação artística. Ainda que, acreditamos, a natureza criadora da memóriaimponha seu modus operandia todos os setores da atividade humana, é necessário que nos detenhamos com a atenção necessária às particularidades que envolvem seu funcionamento em condições específicas de 
produção artística, para que aprofundemos nosso olhar exatamente sobre as implicações que essa natureza criadora pode trazer.

Portanto, nosso objetivo final é construir, ao longo de nosso estudo, as bases argumentativas que sustentem um conceito de depoimento pessoal não mais apoiado na utopia de uma historicidade pessoal impermeável, que pressupõe a apreensão absolutamente objetiva de fatos pelos sentidos e a possibilidade do testemunho exterior isento e estático. Se a memória não é mais tomada como o retorno do sujeito ao passado, e sim como atualização do vivido no presente, pelas condições do presente, então o depoimento pessoal torna-se a história pessoal recriada e delineada pelas especificidades técnicas de cada processo de criação.

Para estruturarmos nosso pensamento de forma a conduzi-lo mais claramente a tais conclusões, iniciaremos nosso trabalho apresentando, na primeira parte, a evolução pela qual o conceito de memória (e, analogamente, o de depoimento pessoal) passou desde a antigüidade até a neurobiologia contemporânea. Esse primeiro recorte, embora pareça demasiado extenso, é fundamental para que o bitor compreenda como o tratamento dado à memória pelas teorias do conhecimento se transfigurou da condição dearte (tradição grecoromana) para a de ciência (modernidade), e as implicações ontológicas daí resultantes para o estudo da memória nos períodos subseqüentes.

É de grande importância que consideremos como o pensamento grego (mais especificamente, aquele platônico e aristotélico, sobre os quais nos debruçaremos com mais atenção) e latino admitia a inter-participação entre as distintas funções da mente/alma, bem como a criação de imagens como parte da atividade mnemônica, conduta que permanece (adaptada às condições ideológicas vigentes, 
evidentemente) no homem medieval, mas se dilui no positivismo posterior emergente, para ser recuperada pelas neurociências da atualidade. Embora não tenhamos encontrado documentação e bibliografia que tratem diretamente da criação do depoimento pessoal no período antigo e medieval (à exceção das práticas oratórias, que relataremos no primeiro capítulo), a análise da mnemônica clássica revela um sistema de formação de imagens que já é em si criativo, e que diz muito sobre a própria arquitetura intelectual e a hierarquia de valores do homem daquele tempo.

Observaremos como a atividade da memória foi compartimentada pelo pensamento científico dos séculos XVII e XVIII, que estreitou os limites operacionais de cada função da mente, e delimitou os âmbitos da memória exclusivamente como retenção, e da imaginação como criação, estabelecendo uma cisão que acompanhou boa parte do pensamento humano sobre o tema até o século XX. Não é de se estranhar que, nesse período, o estudo da memória na criação artística ficasse cada vez mais restrito às mnemotécnicas, e a noção de depoimento pessoal se obscurecesse diante de um quadro teórico que não o contempla enquanto tal.

Na segunda parte de nosso estudo, chegamos às bases filosóficas modernas que ofereceram diretamente o substrato para desenvolvermos o conceito de memória criadora defendido em nosso trabalho. O tempo como apresentado por Bergson (o tempo das multiplicidades e da não-linearidade) foi o conceito-chave e o princípio gerador para compreendermos o movimento mais provável das imagens armazenadas pela experiência no corpo-mente. Foi pela teoria bergsoniana que, primeiramente, tomamos contato com um pensamento que assume integralmente 
a memória como fluxo de vivências pelo tempo, e avança muito na redefinição dos antigos limites para os atributos criação e retenção, ponto fundamental para a evolução de nossos argumentos rumo à formação de uma nova e potente identidade para nosso objeto. De fato, toda definição de corpo-mente e de deslocamento do sujeito pelo tempo que aplicaremos na tese para justificar a memória como recriação é tomada de sua filosofia, e o diagrama do cone antecipa tanto a idéia de atualização dos virtuais da experiência (desenvolvida posteriormente pela cibernética) como dos materiais da memória em relação multilateral e caótica (boca do cone), diretrizes fundamentais para redefinirmos o âmbito de atuação da memória e apontarmos sentidos mais abrangentes para o depoimento pessoal.

O paradigma bergsoniano para memória foi retomando e retrabalhado, mais recentemente, pelo pensamento pós-estruturalista de Deleuze e Guattari e pela cibernética de Pierre Lévy, por meio dos quais combina-se a novos conceitos desenvolvidos por tais autores que qualificam o modelo e fazem avançar na compreensão de seu funcionamento, como veremos no segundo capitulo dessa segunda parte. A perspectiva cartográfica deleuziana de organização do "grande plano” não mais em núcleos duros de conhecimento (ou de estruturas de qualquer tipo), mas de adensamentos fluidos em permanente transformação e contaminação, reverbera fortemente a idéia de tempo e de formação do sujeito e da memória proposta por Bergson. Alinham-se, aqui, pensamentos que privilegiam a dinâmica do tempo e das relações no tempo para formação dos estratos de saber tanto quanto as particularidades de tais estratos, estando, estes, em permanente reconfiguração em devir. 
Tal visão de mundo e de disposição de suas interações como processo dinâmico não linear, múltiplo, simultâneo e horizontal, se alinha à abordagem da memória como matriz interativa apresentada pela cibernética contemporânea. Lévy utiliza a imagem de uma nuvem de virtuais de memória para ilustrar o plano em suspensão, o conhecimento potencial simultâneo e em permanente fluxo com o universo atualizado (presentificado). Essa co-existência dos saberes e das experiências explicaria o fenômeno da criação, pois diferentes unidades de informação armazenadas permanecem vivas mesmo na dimensão virtual, e se combinam de forma inédita pelas demandas do presente. Nesse fenômeno consistiria, exatamente, a chave para a recriação do vivido.

A idéia de uma existência virtual tão viva quanto uma existência atual, cujas forças de atualização se conectam com as relações simultâneas do plano e são por todas elas, direta ou indiretamente, determinadas, vai ao encontro do conceito de memória como fluxo que desejamos desenvolver. Com a teoria da comunicação de Lévy, encontramos o quadro terminológico específico que aprimora e, de certa forma, condensa a análise da memória na dimensão que pretendemos apresentar; e oferece os alicerces teóricos para sustentar a hipótese de memória criadora e de depoimento pessoal como conjunto de virtuais atualizados pelas pressões específicas dos processos de criação que desejamos construir nessa segunda parte da tese.

Por fim, na terceira e última parte, chegamos à análise dos diferentes e mais representativos tipos de depoimento que encontramos nas artes performativas modernas. Como dissemos anteriormente, com os argumentos teóricos apresentados na primeira e segunda partes de nosso estudo, pretendemos ter 
estruturado um conceito consistente de depoimento pessoal a partir da noção de memória como recriação do vivido, o qual agora aplicaremos a processos de criação cujas especificidades técnicas definem identidades heterogêneas para cada depoimento. Desejamos, agora, aprofundar nosso olhar sobre as forças criadoras que pressionam a memória para determinadas formas de disposição dos discursos históricos pessoais, e que são responsáveis pela produção de um tipo de obra, e não outra.

Para tanto, traçamos uma espécie de linha imaginária que vai da personagem do teatro dramático até às performances autobiográficas. No primeiro tipo de processo, a fábula determina e condiciona as circunstâncias pelas quais o ator irá expor seus conteúdos históricos, enquanto no último, a construção total da cena se configura num macro-depoimento pessoal estético, em que os fatos extraídos da biografia do criador podem aparecer mais diretamente relatados dentro da "dramaturgia do performer" específica de cada obra.

Escolhemos como artistas de referência, nesse último modelo, os performers mais ligados à performance art strictu sensu Marina Abramovic, J oseph Beuys e Spalding Gray. Nesse campo da performance art, trouxemos ainda uma prática testemunhal que opera m limite entre as artes, as ciências jurídicas e aquelas terapêuticas: o vídeo-depoimento ${ }^{3}$. O vídeo- depoimento, ao mesmo tempo, põe à prova e impõe um contraponto ético à noção de memória como livre recriação da

\footnotetext{
${ }^{3} \mathrm{O}$ vídeo-depoimento é uma forma de relato que está na fronteira da arte, da terapia e da criminalística, como veremos mais detalhadamente no capítulo final. Trata-se do testemunho de vítimas de violência, geralmente genocídios e grandes guerras ou crimes de estado, para a câmera com pouca ou nenhuma mediação dos entrevistadores. Supõe-se que seus relatos, dado à gravidade dos acontecimentos, deva ser o mais próximo possível dos fatos vividos. Escolhemos incluir o vídeo-depoimento por ser uma prática que, ainda que tenha seu teor artístico questionável no que diz respeito à autoralidade dos meios que definem a obra, problematiza profundamente a memória como recriação do vivido.
} 
experiência, pois trata do testemunho de vítimas de crimes contra a humanidade. Da proximidade com o fato vivido, presente ou não em seus conteúdos, implica uma série de conseqüências que extrapolam as questões artísticas, e dizem respeito tanto a uma possível reparação histórica quanto aos laços culturais que agregam determinadas coletividades e as definem (os judeus, as vítimas das ditaduras latino- americanas da décadas de 60 e 70, etc.).

Entre os dois extremos, personagem dramático e artistas da performance art, situamos como modelo intermediário o trabalho do performer como concebido por Jerzy Grotowski. Sua atividade marca uma clara expansão do âmbito de utilização do depoimento pessoal voltado para a construção da personagem para outro que envolve a produção da cena total como o macro depoimento "estetizado" do artista, como verificamos de maneira mais radical nos processos dos três últimos peformers citados.

Tamanha transição é um dos pontos mais significativos de nossa análise, pois revela como o artista performativo contemporâneo evoluiu de um processo pressionado por forças exteriores de definição do depoimento (a personagem e sua vida interior e exterior, condicionada pelo dramaturgo) para a assunção de uma cena que revela o depoimento pessoal pela composição complexa de todos seus enunciadores. Independentemente das questões de narrativa e de identificação por parte da audiência, a performance exige do artista uma reflexão global sobre a maneira de construir e organizar sua exposição e a tomada de responsabilidade integral sobre a disposição dos materiais que compõem sua cena- depoimento. Não se trata de sugerir hierarquias de qualquer natureza entre os depoimentos desenvolvidos em processos dramáticos e aqueles não-dramáticos, mas de 
exatamente valorizar a riqueza que está nas diferentes forças artísticas que qualificam tais processos, identificando como a memória criadora opera em cada um deles.

Ao fim, e ao cabo, desejamos ter levantado algumas questões que, acreditamos, possam contribuir para o debate mais amplo sobre os mecanismos de criação do artista da cena contemporânea. Pretendemos ter desenvolvido uma argumentação que dê conta de nossa premissa de base: de que a memória não é uma função metafísica, nem um conjunto de eventos marcados estaticamente em nossa identidade. Ela é nossa própria identidade em transformação no tempo e no espaço das multiplicidades. Não há arte que prescinda da memória, pois não há arte que não tenha alguma identidade, assumida ou não. E se chamamos de depoimento pessoal à memória estimulada especialmente para a situação de criação artística, não signif ica que não estejamos exercitando a memória criadora nas diversas atividades da vida cotidiana, reinventando nossa existência diariamente, de forma mais ou menos livre, toda vez que nos relacionamos. 


\section{PARTE 1 - A memória como atributo da mente e suas relações com as demais faculdades humanas.}

Nessa primeira parte, analisaremos de que forma a memória foi estudada pelas principais escolas do pensamento desde Platão até a neurobiologia contemporânea, posicionando-se, primeiro, como atributo e depois como faculdade da mente. Observaremos, especialmente, as transformações na abordagem sobre suas funções surgidas nas passagens dos períodos e com a inevitável substituição dos valores culturais hegemônicos daí decorrente.

De início, vemos que a filosofia grega localiza imediatamente a memória como arte desde a teologia arcaica, em que Mnemósine (A deusa da memória) aparece como a mãe das musas, a quem se deveria evocar antes pedir a inspiração específica. Gradativamente, o culto à arte da memória ultrapassa a devoção à deusa e adquire status mais amplo na sociedade na medida em que a cultura grega encaminha sua evolução não só voltada para as artes em geral, mas para as ciências humanas, naturais, jurídicas e políticas. A palavra, a capacidade argumentativa, a elaboração e memorização dos discursos diferenciam o pensador do homem comum, e, respondendo a tal demanda, produz-se uma outra arte que pode ser exercitada fora das práticas rituais. Nasce a arte da memória per se, conectada, como veremos, tanto à formação direta do conhecimento verdadeiro (Platão) quanto à capacidade de criar imagens e distribuŕlas no espaço (sistema dos locais, place- system aristotélico, etc.).

Analisaremos mais atentamente a teoria do conhecimento platônica no capítulo que se segue, pois a função central da memória nas sínteses cognitivas é 
uma herança iluminadora, que ficou por séculos obscurecida pelo positivismo. Mais do que isso, seu pensamento posiciona a memória entre as mais altas atividades humanas, a produção filosófica, e para além de todo reducionismo que um estudo voltado para e rememoração pode sugerir, o que justifica uma análise diferenciada de sua doutrina.

Entretanto, é interessante ressaltar algumas características do sistema dos locais da memória estabelecido, muito provavelmente, por Simônides de Ceos (de que também trataremos no capítulo seguinte) e que influenciou Aristóteles e inúmeros outros filósofos e oradores a criarem seus sistemas nos períodos posteriores. O sistema dos locais prevê a formação de imagens específicas para as partes do discurso, atribuindo-se relações das mais variadas para cada trecho e local. Veremos como essas associações são sempre criativas, e estimulam a mente a estabelecer diferentes sentidos entre os locais imaginários e os conteúdos a serem associados. Acreditamos que todos os sistemas de locais grego e romano antigos já compunham em si processos de criação do discurso interior para o artista que o exercita, pois solicitam a seleção e disposição criativas das imagens de sua memória pessoal para construir uma trajetória discursiva completamente particular, mais ou menos alegórica, mas sempre única. Não é forçoso reconhecer, aqui, um protoexercício de formação do depoimento pessoal na arte da memória, cuja obra final é o discurso ou poema a ser enunciado.

Nesse sentido, notamos, que a tradição platônica e aristotélica divide espaço, no estudo da memória antigo, com a corrente sofista, cuja abordagem direciona o sistema dos locais para as mnemotécnicas mais especialmente voltadas para a palavra, embora se utilizem para tanto, basicamente dos mesmos sistemas que os 
filósofos aplicavam para recordar dos conteúdos objetivos do conhecimento. Esse modelo orientará, com algumas variantes importantes, todos os principais tratamentos destinados à mnemônica até o fim do Renascimento.

Com o advento do imperialismo romano, a teoria da memória grega, absorvida e "latinizada", sobrevive atrelada à oratória, fundamentalmente em três tratados, todos baseados nos sistema dos locais clássico, mas distintos quanto à natureza das imagens associadas: o Ad Herennium, de autor desconhecido, o De oratore, de Cícero e o Institutio oratoria, de Quintiliano. Analisaremos ainda a importância do De inventione ciceroneano, que, embora seja um documento mais antigo e não direcionado especificamente para a oratória, na medida em que define a função ética da memória como virtude da Prudência, acabou se tornando um dos principais documentos sobre o assunto no medievo (sob o título de "Primeira Retórica” ou “Retórica Antiga”, atribuída equivocadamente a outro autor).

Nesse período, a arte da memória se liga profundamente aos estudos da retórica, mas não se restringe ao âmbito formal da mera memorização do discurso, como uma primeira leitura pode fazer supor. O sistema greco-latino dos locais funciona como um exercício criativo que orienta o fluxo de associações de idéias e formação de representações no pensamento, afirmando-se muito mais como uma cartografia ilustrada da dinâmica particular de funcionamento mental do homem antigo em produção de conhecimento do que como simples manual de exercícios (ainda que também possa ser tomado como tal). A abundante produção a apresentação de textos nas diversas áreas do conhecimento impunham a criação de diferentes imagens, e multiplicam os discursos imagéticos internos resultantes do exercício dos sistemas de locais. Dessa forma, podemos visualizar cada mapa 
mental de imagens e palavras associadas para memorização como pinturas de um discurso pessoal, que se manifesta publicamente na maneira própria do orador executar a enunciação ( observaremos mais profundamente as diferentes "cores" que tais processos adquirem quando nos debruçarmos sobre as imagens sugeridas para associação pelos tratados Ad Herennium e Institutio oratoria, cuja natureza radicalmente distinta sugere mapas mais fantásticos para um e mais miméticos para outro, respectivamente).

Na Idade Média, a arte da memória antiga se descola gradativamente da retórica para se inserir no campo da ética e dos estudos das moralidades, como ademais sucede com quase todas as artes nessa transição. De fato, a oratória desaparece aos poucos, ao passo que o Cristianismo recrudesce, ou, em outras palavras, se transfigura estilisticamente quando deixa de ser a arte do orador autônomo (poeta ou político) e é colocada a serviço da memorização dos sermões. Sua sobrevivência como objeto não-herético de investigação depende de argumentos que a localizem nos domínios das atividades virtuosas do espírito, tarefa a que se dedicam os dominicanos Alberto Magno e Tomás de Aquino, dois dos principais nomes da Escolástica.

Seus tratados retomam vigorosamente a teoria aristotélica para derrubar as críticas que dissociam a memória da Prudência, porém cada autor apresenta um quadro de defesa singular nas obras De bono e Summa Theologiae, respectivamente. A memória participa da doutrinação como instrumento de estímulo das virtudes pela permanente evocação das fortunas, destinadas aos fiéis, e das terríveis danações que sofrem os hereges. Portanto, a formação das representações das qualidades morais e do imaginário coletivo associados aos 
valores cristãos domina a arte da memória medieval e seu estudo, que pouco avança no sentido da criação de novos sistemas mnemônicos ou de outras atribuições para a memória além da catequização pelas imagens. Os discursos menmônicos estão, aqui, terrivelmente atrelados ao medo das punições e à necessidade de salvação da alma, o que, paradoxalmente, em muito enriquece e multiplica a beleza das imagens produzidas pela arte do período (ver toda iconografia do grotesco e da arte gótica, com suas fantásticas alegorias).

A decadência do Cristianismo e, principalmente, o surgimento da imprensa, que pontuam a passagem para o Renascimento, alteram profundamente o estudo da memória como vinha se desenvolvendo desde a antigüidade. De fato, tais eventos marcam o fim da memória como arte, com seus complexos modelos de visualização, que se tornam obsoletos diante das facilidades propostas pelos meios de registro mecânicos emergentes. O estudo da memória é reintegrado ao campo da filosofia pelos neoplatonistas, numa abordagem que abre espaço para a perspectiva moderna de análise da memória não mais ligada à oratória, como na cultura latina, nem sob o jugo da moral, como no período medieval, mas como função autônoma da mente/ alma.

Passamos, então, a uma revisão das principais correntes científico-filosóficas modernas que tratam propriamente da memória como faculdade do espírito, a fim de observar como se cristalizou, ao longo de nossa história, o dualismo retençãoreflexão (criação) no pensamento moderno a partir da já resgatada herança antiga e medieval. René Descartes, em suas obras de referência sobre metafísica e método, introduz a memória como faculdade, função da mente/espírito no campo das ciências modernas. Seu âmbito de atuação, entretanto, é condicionado pelos 
paradigmas estritos da racionalidade como atividade intelectual restrita ao centro cortical, que estabelece com o "resto"' do corpo uma relação unidirecional de controle autônomo. Na separação res cogitans, res extensa, a memória está claramente limitada a seu caráter retentivo, como uma conservação incompetente das impressões (a acepção antiga de memória, contra a qual se opõe a reminiscência ativa de Platão), que mais confunde do que auxilia o pensamento. A perspectiva cartesiana, ao passo que busca isolar as faculdades e delimitar suas atividades, acaba por fundar o estatuto de tratamento da memória que exatamente se opõe à noção de memória criadora que defendemos em nossa tese, pois atribui à faculdade apenas a capacidade de armazenar os dados sem, no entanto, modificalos de alguma forma. Trata se, pois, de uma aptidão passiva da mente.

A contra-corrente empirista, cuja representação mais contundente, acreditamos, está na obra de David Hume, numa primeira leitura parece insistir na memória como retenção e como faculdade inferior, submetida, desta vez, às leis associacionistas da percepção. Observaremos, porém, como a releitura proposta por Deleuze do pensamento humeano permite revelar, por trás do pesado projeto empirista de hegemonia do aparelho perceptivo, novas funções mais complexas e extensas para memória, especialmente se avançarmos na idéia da cooperação permanente com a fantasia como uma premissa fundamental de operação das sínteses do conhecimento.

Por fim, chegamos às ciências contemporâneas como um capítulo- adendo do qual não podemos prescindir para a produção de uma reflexão verdadeiramente atualizada sobre a memória e suas funções. A neurobiologia desenvolveu suas pesquisas nos últimos cinqüenta anos em um sentido que transcende a aplicação 
terapêutica e pode auxiliar profundamente o estudo da mente nas artes em geral, especialmente quando busca definir os graus de contaminação e œ-ação entre as ditas faculdades da mente. Os trabalhos de Ivan Izquierdo e Antonio Damásio, respectivamente no campo do mapeamento cerebral e do neurocognitivismo, indicam os caminhos por onde o estudo do cérebro com as novas tecnologias de visualização de sua atividade podem levar, no sentido de identificar e iluminar as transformações que o corpo sofre em todo tipo de vivência ${ }^{4}$. Os estudos sobre depoimento pessoa, não devem, e não podem, fechar os olhos para as descobertas da ciência de seu tempo, cuja análise, ao longos das décadas recentes, vem se desligando do sectarismo cartesiano para buscar uma perspectiva mais holística de funcionamento da atividade mental.

Acreditamos que somente pela colaboração mútua entre ciência e filosofia, em que ambas as aéreas estejam reconhecidas como produtoras igualmente legítimas e autônomas de saber em cooperação, é que poderemos chegar a um entendimento realmente potente e consistente da memória como fluxo e como recriação, parte de um sujeito em eterno processo de construção e destruição, que se desdobra pelo tempo e devém universo em relações, invariavelmente, criativas.

\footnotetext{
${ }^{4} \mathrm{O}$ conceito de vivência que utilizamos em nosso estudo opera na tensão entre unidade vivencial e relação intencional discutida por Hans-Georg Gadamer em sua obra Verdade e Método I, pp 99-116. Ou seja, é construída no choque das intencionalidades com a totalidade da vida e em seu ultrapassamento.
} 
Capítulo I - Do inatismo platônico à Renascença

A memória (mnêmoneuein ou memnêsthai) perpassou quase todo o período présocrático atrelada à teologia grega arcaica. Mnemósine era a deusa da lembrança e do esquecimento, e de suas vontades, seu "humor" e da capacidade de invocação de seus devotos advinha o melhor ou pior talento na recuperação dos fatos para cada indivíduo. Era a progenitora das musas, portanto, dela nasceram aquelas que distribuem os talentos artísticos: em última instância, da memória nasce a Arte. E da mitologia, devém a hipótese fundamental de nossa tese, que, nesse sentido, rende tributo à tradição grega: não há fazer artístico que prescinda da memória, bem como nenhuma outra operação do conhecimento. Tentaremos provar que a arte que se pretende um recorte veloz do presente imediato, atemporal, descolada da macro-história, apenas recusa a reflexão sistemática e formal sobre sua condição, mas não escapa à historicidade pessoal do corpo como adensamento fluido em devir.

O exercício do "lembrar" era de grande importância para o cidadão grego, e, de fato, para todo grupamento humano cujas tradições são transmitidas oralmente. Em uma época em que a escrita e os registros artísticos em geral eram restritos a poucos, a imprensa e nenhuma outra forma de reprodução mecânica existiam, aquele que tivesse o dom da lembrança adquiria poderes especiais diante da coletividade: é o historiador, o poeta e, para Platão, o filósofo que acessa o mundo perdido do conhecimento das vidas passadas. O avanço da oratória a partir de Homero se alinha ao desenvolvimento dos estudos da mnemotécnica, que, logo veremos, avançam rapidamente rumo à formação de uma arte da memória. 
Encontrar mecanismos que permitissem a rememoração dos argumentos e das idéias na hora desejada tornou-se objeto próprio de investigação, forçando um olhar de retração de seu domínio ao âmbito do "humano" para melhor apreendêlo. Acreditava se que a memória natural poderia ser ampliada por meios artificiais e nisso consistia a arte da memória de então: os métodos pelos quais os homens poderiam deliberadamente dilatar a memória espontânea. Tais métodos se baseiam no princípio do deslocamento da alma por imagens construídas que remetem ao próprio trânsito do pensamento, restaurando o vivido pela reativação dos sentidos, e, por tanto, parece mais uma arte da ação do que de sujeição às técnicas:

\begin{abstract}
“Embora seja importante reconhecer que a arte clássica é baseada em princípios mnemotécnicos eficientes, talvez seja enganoso aplicar o rótulo 'mnemotécnicas' [...] As memórias antigas eram treinadas por uma arte que refletia a arte e a arquitetura do mundo antigo, e dependia da faculdade da intensa memorização visual, que nós perdemos. A palavra 'mnemotécnicas', apesar de não estar errada como descrição da arte da memória clássica, faz esse assunto misterioso parecer mais simples do que é." 5
\end{abstract}

A re-evocação projetava a obra (ou o discurso) à imortalidade através da reinstauração não só dos conteúdos, mas de toda experiência que lhe envolveu originalmente, fortalecendo, em última instância, além da aura/imanência do evocado, as relações da coletividade que participou de sua criação.

A paternidade da arte da memória clássica é creditada a Simônides de Ceos (circa 556-468 a.c.) , poeta pré- socrático cujo caso do trágico banquete de Scopas é passagem recorrente nos estudos da memória antigos. ${ }^{6}$ Rapidamente, a história conta que um dia Scopas, um nobre da região da Tessália, deu um grande banquete

\footnotetext{
${ }^{5}$ The Art of Memory, p. 4. Tradução minha. Todas as citações referentes ao livro foram livremente traduzidas do Inglês por mim.

${ }^{6}$ Há divergências sobre a localização real de onde teria ocorrido o banquete, se nas cortes de Farsalus ou Crano, conforme explica Quintiliano no tratado Institutio oratoria, XI, ii, 14016. Op. cit., p. 27.
} 
para muitos convidados em seu palácio, e que, a certa altura, o poeta, que participava da festa, entoou um poema lírico ao seu anfitriãa O poema continha também uma passagem de evocação aos deuses Castor e Pólux, e Scopas, brincando, disse que faria apenas metade do pagamento a Simônides pelo trabalho, pois a outra metade ele que cobrasse dos gêmeos sagrados aos quais ele rendera tributo.

Minutos depois, Simônides é avisado que havia dois jovens fora do palácio esperando para lhe falar. Ele sai, procura-os, mas não encontra ninguém. E, enquanto está nessa busca, o teto do palácio cai matando Scopas e todos os convidados. Nos dias que se seguem, parentes vêm de todas as partes para identificar os mortos, mas a tarefa é impossível, pois os corpos estão deformados e irreconhecíveis. Graças a sua mnemônica apurada, Simônides recorda exatamente cada uma das vítimas pela localização em que estavam sentados durante a refeição, e resolve a questão, louvando a Castor e Pólux por tão generoso pagamento.

Eis a estrutura fundamental da arte da memória a partir da qual todos demais pensadores da antigüidade grega e latina farão suas revisões: a associação entre locais imaginados e conteúdos a serem lembrados ${ }^{7}$. Tal sistema se liga a uma abordagem creditada por Plutarco a Simônides que equaciona os procedimentos na pintura e na poesia para encontrar seus denominadores comuns de criação: "Ele chamava a pintura de poesia silenciosa e a poesia de pintura que fala". ${ }^{8}$ Simônides identificou a visão (seguida da audição) como o mais importante atributo na hierarquia dos sentidos que fixam as informações da memória, de onde

\footnotetext{
${ }^{7}$ Simônides foi o primeiro poeta a estabelecer pagamento para suas criações, a partir de que, provavelmente, se instaura a relação mais emergencial e profissional com o tratamento da memória, pois a apresentação correta dos poemas torna-se "exigência contratual" da profissão.

${ }^{8}$ Op. cit., 28.
} 
vem a semelhança entre o trabalho do poeta e do pintor na disposição dos elementos pelo espaço visual, o último utilizando as imagens como linguagem, e o primeiro, as palavras.

A partir dessa comparação, criou-se um sistema de arte da memória que toma nichos espaciais visualizados mentalmente em disposições específicas como moradias de determinados conteúdos (de discursos, de poemas, etc.) a serem lembrados. Assim como os convidados ocupavam certos locais na sala quando o palácio desabou, e a recordação visual de suas disposições permitiu o reconhecimento de suas identidades, Simônides concebeu que as informações podem ser distribuídas espacialmente na mente em unidades de espaço imaginadas e definidas com precisão, às quais é possível associar objetos que se deseja memorizar.

Esses locais (toppoi) devem ser criados com máxima qualidade visual, a ponto de formarem uma verdadeira arquitetura das unidades: um edifício, uma rua, uma palácio, enfim, uma maneira objetiva e específica de dispor na mente, da forma mais clara possível, a estrutura e a relação entre as unidades. Tal rigor é necessário, pois dele depende a efetividade da etapa seguinte. Para cada unidade associam- se objetos a serem lembrados. Essa associação precisa se dar por critérios que privilegiem a rápida identificação dos espaços com os conteúdos, e acelerem seu reconhecimento. Os mitos antigos, linguagem do imaginário coletivo do período, surgem como alternativa mais provável, como vemos no trecho a seguir: “Por exemplo, se Chrysippus é quem deve ser relembrado, nós o colocamos em ouro e cavalo [...] assim funciona para nomes. Da mesma forma para as coisas: 
para coragem, localizamos em Marte ou Aquiles, para o trabalho com metal, em Vulcano; e para covardia, em Efeu."9

Estando claramente estabelecida a visualização dos espaços e as associações com os conteúdos residentes, basta ao espírito promover um passeio imaginário pelos locais que imediatamente viriam à mente seus moradores. Se são trechos de um poema ou de um discurso, uma lista de nomes, outras imagens, elas surgem quando a mente se aproxima dos toppoi específicos. Observemos que, ainda que o processo seja o mesmo, o autor diferencia o procedimento de associação para “coisas" e para palavras. Tal separação é questão central no embate posterior entre Platão e os sofistas sobre a função da oratória e as possíveis hierarquias entre a mnemotécnica para decorar discursos (palavras) e a memória como operação filosófica superior.

A passagem acima foi extraída de um tratado anônimo intitulado Dialexis, e que data de aproximadamente 400 ac. Reflete mais fortemente uma apropriação da arte de Simônides ao gosto dos sofistas, cujo sistema educacional privilegiava a memorização por quantidade e variedade de dados que permitiram ampliar as possibilidades estéticas do discurso. Conseqüentemente, a lembrança da palavra e a composição formal do texto estão na base das práticas, orientação que será fortemente combatida por Platão. Trataremos mais profundamente da memória na teoria platônica a seguir, mas está claro que para o filósofo das idéias puras a memória tem função muito mais complexa e determinante na construção do conhecimento do que apenas associar palavras para a bela enunciação. Ela é a operação que permite o contato com as formas perdidas, com o saber verdadeiro.

${ }^{9}$ Op. cit., p. 30. 
Eis porque, para Platão e para os demais filósofos de sua descendência, a memória das palavras denota à memória sofista: um truque, uma técnica oratória formal e vazia que busca efeitos de apresentação e está centrada na representação, não na essência dos fatos. A esta, ele opõe a memória das coisas: recordação ativa e autêntica da verdade transcendental.

Como vimos até agora, o pensamento de Simônides contém as formulações básicas da arte da memória. Tais formulações são o reflexo das profundas transformações por que a sociedade grega passava, cuja organização em classes delimitava mais claramente o âmbito das atividades e sua remuneração. Para os poetas, a passagem para a profissionalização envolve a criação de procedimentos mais sofisticados e eficientes que definam as especificidades de sua techné:

\footnotetext{
"As invenções supostamente introduzidas por Simônides talvez sejam os sintomas da emergência de uma sociedade mais organizada. Os poetas, agora, têm seu espaço na economia, e a mnemotécnica praticada no período da memória oral, antes da escrita, precisa ser codificada em regras. Em uma época de transições para novas formas de cultura, é normal que algum indivíduo excepcional seja rotulado de inventor."10
}

Assim, a experiência de Simônides em tal contexto, e seus desdobramentos no pensamento e nas artes gregas, marca o nascimento da memória como arte e como atributo da alma. É interessante observar que o sistema inicial é fundamentalmente descritivo: relata o movimento da alma pelo edifício das lembranças e sua construção. Remete muito mais a uma noção de processo do que de faculdade. Embora seja relativamente conservador ao privilegiar imagens de caráter mimético como mais eficientes para evocação dos conteúdos dos locais (que deveria criar uma espécie de "cena realista" memoriosa, por assim dizer, na mente

${ }^{10}$ Op. cit., p. 29. 
do praticante), esse primeiro modelo de sistema já exige, para seu correto funcionamento, uma intensa atividade criadora, não só para escolher as imagens visuais a serem memorizadas como para qualificá-las com as cores específicas que caracterizam as construções simbólica de cada mente em particular. Relembrando a citação sobre os paralelos entre pintura e poesia sugeridos por Simônides, fica mais fácil apreender o sistema dos locais antigo como um método de criação interior que combina desenho/pintura e poesia na sua concepção, e a enunciação falada na sua expressão. À sua maneira, tal método já exige a disposição dos conteúdos históricos do artista para elaboração das imagens a serem associadas aos textos, mesmo que sua expressão final não se dê pelas formas, senão pelos sons.

Paralelamente à sistematização da arte da memória, Platão surge como o primeiro grande pensador a inserir efetivamente a arte da memória na teoria geral do conhecimento. A mnemônica platônica é a arte de cultivar a memória em consonância com a sua teoria do conhecimento inato, problematizando o ato de recordar para além de modelos técnicos de fixação interior e reprodução de imagens e textos tratados até então. Na República11, Platão define sua teoria da reminiscência, sugerida no exercício maiêutico do diálogo Ménon, detalhada em

\footnotetext{
${ }^{11}$ Da mesma forma como se utiliza das alegorias do mito da caverna para ilustrar a relação entre o mundo sensível e o mundo inteligível, Platão, no mesmo livro, conta a história do mito de Er para tratar da função da memória e do esquecimento. Em breves palavras, o pastor Er morre, e é levado ao Hades, onde encontra diversos heróis, amigos, artistas e parentes queridos que lá contemplam o conhecimento absoluto. Porém, Er lá descobre que o sentido da morte é oferecer aos homens a oportunidade de renascer e, assim, se purificar em seu retorno e na nova vida dos erros da existência anterior. Portanto, é perguntado aos mortos como gostariam de voltar à Terra. Muitos dizem que gostariam de voltar como reis, nobres, ricos comerciantes. Outros, pedem sabedoria e uma vida mais modesta, e partem todos de regresso ao mundo dos vivos navegando pelo rio Lethé (esquecimento). Na viagem de volta, aqueles que foram mais gananciosos sentem muita sede, e bebem descontroladamente a água do rio. Não sabem que essa água tem o dom de promover o esquecimento de todas as formas belas, do conhecimento e da verdade que experimentaram no Hades, por isso voltam ainda mais ignorantes à Terra do que quando partiram. Ao contrário, aqueles que escolheram uma vida de moderação, não sentem tanta sede, bebem menos da água do esquecimento e retornam mais sábios à vida, reduzindo o ciclo de morte e renascimento e antecipando seu aprendizado da verdade. Eis, em tons claríssimos, a perspectiva do filósofo sobre as relações entre prazer do corpo e conhecimento.
} 
Filebo e esclarecida na totalidade de ação dentro de seu projeto filosófico em Fédon, em cuja base está a própria essência do conhecimento, seu acesso, seus atributos e sua relação com o corpo. A memória se divide em duas categorias, de natureza e função quase opostas, e que estão comprometidas com processos antagônicos no que tange à qualidade de aprendizado do filósofo.

A primeira é a conservação de sensações. Essa memória passiva é uma permanência dos dados da percepção sensível na alma, se cria involuntariamente e não está envolvida monsamento (noêsis), ao contrário. Ela alimenta a doxa (opinião) e não a epistéme (conhecimento inteligível), pois seu conteúdo é mediado pelo corpo e carrega todas as ilusões que caracterizam as experiências por ele vivenciadas. Ela é quase como um resíduo na alma que surge indeterminadamente (uma lembrança espontânea) e, não encontrando outra tarefa senão revelar a si mesma, esgota-se tão logo se fixe outra percepção.

A outra é a reminiscência (anamnese), atividade de recordar, que para Platão, não é outra coisa senão aprender12. A recordação é um movimento voluntário, que deve ser cultivado pelo filósofo por meio da boulêsis (vontade, aspiração racional), pois nela consiste o acesso ao conhecimento verdadeiro que, conforme observamos no mito de Er, reside no mundo dos mortos e era acessível aos homens antes da vida terrestre, quando ainda estavam livres dos desejos e da escravidão do corpo $^{13}$.

\footnotetext{
12 “Aprender, diz ele, não é outra coisa senão recordar”. Cebes citando Sócrates. Fédon, p.99.

13 "Por conseguinte, volto a repetir, de duas uma: ou nascemos com o conhecimento das idéias e este é um conhecimento que para todos nós dura uma vida inteira - ou então, depois do nascimento, aqueles de quem dizemos que se instruem nada mais fazem do que recordar-se, e neste caso a instrução seria uma reminiscência.". Ibid.p.104.
} 
É através da recordação que a alma toma contato não com o mundo dos deuses diretamente, mas com o pré-natal da humanidade, onde estão as formas que representam o conhecimento absoluto, às quais as almas imortais estavam conectadas antes de nascerem. A recordação, portanto, está na base do inatismo platônico como o operador que afasta a alma da crença no mundo sensível e na mutabilidade das coisas, e que a re encaminha e preserva dos meandros instáveis da percepção ${ }^{14}$ para aproximá la do conhecimento considerado real. Em última instância, a recordação, ou reminiscência, aproxima o homem de um conhecimento de que ele já dispôs ${ }^{15}$, ou que em algum momento conteve em si, e que éapagado pela má orientação do sujeito em sua relação com o saber.

Em Ménon, é celebre a passagem em que o filósofo, por meio de perguntas e respostas direcionadas, leva o escravo inculto a resolver um difícil teorema de geometria apenas pela solução de perguntas estratégicas por ele propostas na sequência correta, comprovando a hipótese de que o acesso às idéias verdadeiras é possível até mesmo a um analfabeto mediante uma atitude filosófica apropriada. A teoria da reminiscência, ali, está sugerida poeticamente, mas não esclarecida como no diálogo seguinte.

Em Filebo, Platão insere a memória como um dos elementos centrais de sua lógica argumentativa a favor do raciocínio no embate entre os hedonistas Filebo e Plotarco contra Sócrates pelo primado do prazer ou do conhecimento como princípios mais vantajosos para a vida de todos os seres. Além de situar mais

\footnotetext{
${ }^{14}$ Há de se considerar, nesse contexto, o valor que Platão confere à associação de imagens como fomentadora da recordação, fenômeno somente possível pela percepção, uma vez que todos os exemplos de recordação que ele apresenta no diálogo partem de informações obtidas pela experiência sensorial. $C f$. Ibid. pp. 101-105.

15 "Saber, com efeito, consiste nisso depois de haver adquirido o conhecimento de alguma coisa, dispor dele e não mais perdê-lo. Aliás, o que denominamos 'esquecimento' não é, por acaso, o abandono de um conhecimento?". Cf. Ibid. p. 104.
} 
especificamente a função de memória no quadro conceitual de sua metafísica, da forma como já a apresentamos, Platão define para essa uma outra qualidade de grande importância em sua teoria do conhecimento, particularmente no que se refere à doutrina de geração dos opostos: é através dela que a alma se coloca em movimento para preencher os vazios do corpo e do espírito, para levar o homem aos seus objetos de desejo e satisfazer seus impulsos.

Com esse argumento, ele comprova sua hipótese de que os prazeres verdadeiros nascem da alma, uma vez que a memória está entre os seus domínios, e não do corpo, cujos desejos defendidos pelos hedonistas são resultados de percepções enganosas. Os impulsos, verdadeiros ou falsos, conduzem sempre à busca pelo contrário para se atingir a saciedade, e é pela memória que se determinam todos os registros de cheio e de vazio, das sensações em si e de seus opostos.

Finalmente, em Fédon, a memória está completamente inserida na análise sobre o destino das almas, na existência da vida após a morte bem como da vida antes do nascimento (justificada pela geração dos opostos) e no reconhecimento definitivo da filosofia como a preparação do homem para o desligamento do corpo. Esse desligamento, certamente, está como o ápice de uma caminhada do indivíduo rumo ao conhecimento verdadeiro. A deterioração e falência do corpo é o abandono sábio que a natureza oferece ao homem de tudo que lhe é precário e que lhe permite construir uma visão igualmente precária do Universo.

Nesse processo, o homem que exercitou a ato de recordar estará melhor preparado para a morte, pois está mais íntimo dos conteúdos verdadeiros. Em vida, guiou-se na busca pelo real e pelo belo, e não pela satisfação dos sentidos, e através 
dos desejos corretos elaborou as perguntas apropriadas a um sábio e desenvolveu o raciocínio sobre o real, o que, em última instância, lhe transmuta gradativamente de alma-em-corpo para idéia pura. Sob essa perspectiva, a passagem para a mortee para o transcendente ideal não é dolorosa, pois o homem neste estado já está naturalmente se encaminhando para o mundo dos mortos. Em Fédon, por tanto, é possível observar mais definitivamente como a memória atua na trajetória de ascensão às formas.

Não é exagerado afirmar que a metafísica platônica estabelece algumas diretrizes que são definitivas para as futuras reflexões sobre a memória e suas funções. A saber:

a) A divisão da memória em categorias conforme a natureza de seu funcionamento (no caso, conservação de sensações para memória passiva, a que Platão de fato denominava memória, e reminiscência para memória ativa).

b) A memória como faculdade em relação com as demais aptidões da alma.

c) A atividade mnemônica como processo fundamental dentro de uma teoria do conhecimento.

São conclusões que fundam a primeira base filosófica para se pensar a arte da memória como processo intrínseco à formação do sujeito, superando definitivamente a herança da mnemotécnica como puro exercício de retórica. De fato, o que exige revisão é o conceito de oratória que aplicamos. Para Platão, o orador mnemônico é, em última instância o verdadeiro filósofo: relator do conhecimento real adquirido pela recordação. A este, se opõe o orador sofista que, pintando em cores grosseiras, utiliza as técnicas de memorização decorativamente 
para adornar as formas do discurso ao invés de direcioná las para a busca dos conteúdos do saber verdadeiro.

A memória como operação de acesso ao conhecimento inato, proposta por Platão, é um primeiro paradigma a partir do qual os demais filósofos terão substrato para refletir sobre as relações entre o que se define por recordar e reter e as demais atribuições da alma com o corpo nos séculos seguintes.

A distinção entre os dois tipos de memória continua em Aristóteles ${ }^{16}$, que, seguindo a orientação do mestre, estudará a faculdade em relação com as demais funções em sua teoria do pensamento. O tratado De Memória et Reminiscentia era, originalmente, uma apêndice do De Anima, e, por tanto, é parte de seu estudo sobre a formação do pensamento no corpo e na alma, em que a percepção aparece como eixo de construção do conhecimento.

Como Platão já antecipara em sua teoria sobre a memória dos sentidos, Aristóteles compreende que a formação da memória se dá por uma série de impressões, marcas de um acontecimento delimitado e apreendido pelo aparato sensorial que se registram na alma como um quadro. Tal quadro remete tanto ao objeto (ou situação) que ele representa quando à imagem em si, e ainda, que não sejam a mesma coisa (o acontecimento original e o seu símbolo mnemônico) são ambos conteúdos da memória. Ou seja, a marca contém tanto a imagem de representação quanto o objeto representado. Porém, para Aristóteles, quando a imagem é a cópia e semelhança do objeto representado, ela é uma imagem que produz conhecimento, um eikôn, não porque abre uma conexão com o absoluto

\footnotetext{
${ }^{16}$ Sorabji in Aristotle on Memory utiliza os termos remembering e recollection para diferenciar a memória e a recordação (reminiscência) na teoria de Aristóteles.
} 
transcendental, mas porque promove o resgate de uma informação percebida. As imagens percebidas pela experiência dos sentidos não significam o desvio no aprendizado das formas, mas exatamente o contrário: são a verdadeira fonte de saber.

Aristóteles compreende que esses processos de registro são de natureza física tanto no caso das reminiscências quanto da conservação de sensações, e não apenas operações da mente e da alma (como de resto pressupõe toda construção do saber em sua teoria). As imagens são tentativas da alma de apreender o sensível, e essa operação é imprescindível para a formação das idéias. ${ }^{17}$

A construção da representação é uma etapa importante na teoria da memória de Aristóteles, pois explica a importância da percepção no processo. As imagens sensoriais, às quais ele chama de aisthêmata, não são as imagens da memória. As aisthêmata são marcas impressas na alma, que produzem a posteriori as imagens da memória. Essa passagem se dá pela ação da imaginação que plasma e relaciona os conteúdos da percepção. As aisthêmatas não produzem conhecimento por si, são imagens fixadas isoladamente pelos cinco sentidos, cada um trabalhado de forma autônoma. É a imaginação que faz a mediação entre a percepção e o conhecimento quando trabalha simbolicamente as aisthêmatas preparando-as para as operações superiores do conhecimento. As imagens da memória nem sempre se referem diretamente ao objeto percebido, mas podem se referir à própria imagem percebida erroneamente (o que justificaria as imagens irreconhecíveis ou sem sentido imediato, além dos sonhos).

\footnotetext{
${ }^{17}$ Ao contrário de Platão, para quem o conhecimento poderia ser produzido mediante a organização dialética das idéias, com pouca ou nenhuma participação das imagens, Aristóteles argumenta que um número muito reduzido de idéias pode ser articulado sem a experiência sensível, por isso a necessidade de secriar imagens como registro dessas experiências.
} 
A memória retentiva é passiva e comum a outros animais, enquanto a recordação é uma dedução, um silogismo possível, portanto, somente ao homem. É uma dedução porque pressupõe a consciência de que o evento já foi vivenciado e propõe uma espécie de busca (ativa, voluntária) da imagem de referência através de associações. Ambas, são, para Aristóteles, criadas por movimentos da alma en relação ao habitat: diferentes movimentos criam memórias de diferentes naturezas. Estabelece-se, aqui, uma distinção que irá percorrer o estudo da memória (e também, da imaginação) até a modernidade no que diz respeito à clareza de representação das imagens. No pensamento aristotélico, o eikôn é a imagem que produz conhecimento, aquela que imediatamente identificamos com o material referenciado, enquanto as outras são como impressões confusas ou parciais do percebido (phantasmas, as imagens em geral).

É surpreendente o salto que representa a teoria da memória de Aristóteles quando redefine o status da percepção e da imaginação na cooperação das faculdades para produção de conhecimento. Sua perspectiva sobre a impartância do aparato sensível e fabulador para a formação das idéias permitiu que desenhasse (em seus termos e com a tecnologia de sua época) um modelo de funcionamento anatômico que já pressupõe a existência de canais aferentes e eferentes de percepção que se comunicam com um centro; e a criação como operação que permite fundir ou dissolver os conteúdos da percepção e atribuir-lhes (ou descobrir-lhes) novos sentidos:

“O De memoria et reminiscentia é um apêndice do De anima que abre com uma citação dessa obra: 'como foi dito anteriomente em meu tratado De anima sobre a imaginação, não é possível nem mesmo pensar sem uma imagem mental.' A memória, ele continua, pertence à mesma parte da alma que a 
imaginação, é uma coleção de imagens mentais oriundas das impressões dos sentidos mas com um elemento adicional, que as imagens mentais da memória não vêm de uma percepção das coisas do presente, mas do passado. A memória, nesses termos, como impressão dos sentidos, não é peculiar apenas ao homem os animais também a possuem. Todavia, a faculdade intelectual se manifesta pelo trabalho da memória sobre as imagens armazenadas da percepção dos sentidos." ${ }^{\prime 18}$

A qualidade do armazenamento das imagens, curiosamente, é relacionada por Aristóteles ao temperamento e à idade do indivíduo. A melhor idade da memória seria nem muito jovem nem muito velho, já que, em ambos extremos da vida do homem, sua fisiologia está disposta em condições inadequadas para a fixação das impressões:

“...o muito jovem e o muito velho têm memórias pobres, pois estão em estado de fluxo, o jovem por causa de seu crescimento, o velho por causa de sua decadência. Por motivo semelhante, nem o muito rápido nem o muito lento parecem ter boa memória, o primeiro, por que é mais úmido do que deveria ser e o último, mais duro; no primeiro, a imagem não permanece, no segundo, não se imprime."19

Notemos que também aqui estão intuídos conceitos desenvolvidos muito recentemente sobre fluxo de informações e níveis de armazenamento das imagens, e sobre a formação da memória como um processo que depende das condições totais dos corpos e suas particularidades.

No campo da mnemotécnica, Aristóteles cita em seu tratado da memória como mais eficiente o place-system ( place = lugar, topoi). O place-system adapta a arte da memória como já estruturada no modelo de Simônides para o contexto específico de uma rua. Associam-se as informações como se estivessem em uma rua cheia de casas diferentes. Primeiro, é preciso visualizar com clareza e sem risco

\footnotetext{
${ }^{18}$ The Art of Memory, p. 33.

${ }^{19}$ Op. cit., p. 33.
} 
de alteração cada uma das casas. Depois, oolocam- se palavras chave ou trechos de um discurso em cada uma das casas conforme a ordem em que se criou o percurso pela rua. Então, conectam-se a imagem dos locais às palavras ou trechos, e, à medida que o orador imagina percorrer os locais, aparecem na memória os trechos do discurso que estão relacionados a cada casa.

Em linhas gerais, podemos observar que pelo menos três pressupostos fundamentais para o estudo da memória criadora nos foram herdados dos pensamentos platônico e aristotélico. São eles:

1) A distinção entre memória retentiva e reminiscência (recordação).

2) O contraste entre o caráter passivo e natural da memória retentiva e o caráter voluntário e ativo da recordação, que a aproxima do silogismo apodíctico.

3) As bases físicas da memória como movimento na alma.

4) O corpo como agente condicionante da formação das imagens

5) A cooperação entre as faculdades na produção do conhecimento intelectual.

Esses princípios chegam através de registros esparsos e fragmentados nas transfusões para o pensamento subseqüente. A abordagem filosófica da arte da memória é assimilada pelos estudos da oratória latina com ênfase nos princípios instrumentais da mnemotécnica, especialmente no sistema dos toppoi de Simônides e no place-system de Aristóteles, mas sem negligenciar a natureza criadora intrínseca a tais métodos, como observamos nos três principais tratados sobre o assunto do período: o Ad Herennium, o De oratore e o Institutio oratoria. 
O Ad Herennium é o único documento sobre a arte da memória inteiramente completo que sobreviveu da antigüidade grega e latina. Foi escrito por um professor de retórica, cujo nome não se descobriu ${ }^{20}$, entre 86 e 82 a.c., e possivelmente se endereçasse aos seus alunos da disciplina, dada a disposição dos conteúdos e a concisão da linguagem utilizada. O autor analisa as cinco partes da retórica (inventio, dispositio, elocutio, memoria, pronunciatio) e define a memória como atributo fundamental do bom orador, cujo trecho referente ele inicia distinguindo a memória natural da artificial.

A memória natural é aquela que foi colocada na alma no nascimento, junto com o pensamento e as demais faculdades. A memória artificial é aquela que é fortalecida pelo treinamento. Ou seja, toda memória artificial não é outra senão a memória natural de cada indivíduo potencializada pelos exercícios mnemônicos, de onde se conclui que todo homem, por mais jovem, velho au inábil que seja, pode melhorar sua memória pela aplicação da mnemotécnica.

No Ad Herennium, a arte da memória está claramente apresentada como escrita interior (do poeta ou do aluno que utilizar o sistema) articulada pela formação e navegação entre os simulacros. Sua construção é minuciosamente detalhada, com atenção especial para a qualidade de visualização dos loci (toppoi), os locais criados artificialmente pela imaginação em que os conhecimentos se alojarão, que representam, em última instância, os significantes imaginários do proto- semiólogo antigo.

\footnotetext{
${ }^{20}$ Uma corrente de pesquisadores credita ao próprio Simônides ou a algum de seus alunos romanos a autoria do Ad Herennium, tamanha a semelhança entre sua arte da memória e esta apresentada no tratado.
} 
Os loci não devem ser muito parecidos e nem colocados muito próximos uns dos outros no diagrama das imagens para evitar confusões na hora da associação. Assim como nas descrições gregas, o autor se utiliza da metáfora dos tabletes de cera para conotar os loci, cujo registro na mente deve ser mais forte do que os conteúdos que lhes ocupam. Um loci criado adequadamente permanece na memória mesmo quando esgotada sua utilidade imediata, e pode ser re-utilizado para armazenar outras informações quando necessário.

Cada local deve funcionar como unidade autônoma dentro do movimento dos discursos, permitindo que o criador se mova de um loci para outro em ordens diferentes conforme a natureza associativa do que se deseja evocar. Quanto mais materiais se queira lembrar, mais loci precisam ser formados, e o autor sugere que a cada cinco unidades se estabeleça uma marca que oriente a localização (algum símbolo para cinco marcado no quinto loci, outra imagem referente a dez no décimo, e assim sucessivamente). Notemos que esse sistema, embora trabalhe com a ordem linear da progressão numérica, prevê o deslocamento da mente em diversos sentidos pelo desenho dos locais, o que sugere não tanto uma seqüência, mas um mapa horizontal de possibilidades de conexão entre os nichos.

A princípio, os critérios de associação entre as imagens dos loci e seus conteúdos parecem seguir as indicações anteriores, que buscam as analogias mais fáceis e imediatas. Para os loci, imagens de locais reais: salas, prédios, esquinas, construções, etc. Porém, na medida em que se atribuem qualidades aos locais, abrem-se maiores possibilidades de ligação com os conteúdos, ou seja, os conteúdos podem exatamente qualificar os loci, e facilitar sua associação, é o que nos diz o autor do Ad Herennium. 
De um modo geral, eles não devem ser muito grandes para não ocupar espaço demais na mente e desequilibrar o mapa; nem pequenos demais para não criar um excesso de micro-unidades de difícil visualização.

A descrição dos loci vai ainda mais longe, e define que eles não devem ser nem muito brilhantes, para não ofuscarem as imagens neles contidas, nem muito escuros para não ocultá-las. É mais útil que seus intervalos sejam de distância moderada, pois: "assim como o olho externo, o olho da mente é menos poderoso quando você se move para um objeto cuja vista está muito perto ou muito longe."21 Ao final da descrição sobre a construção dos loci, o autor nos surpreende com um apontamento a mais em relação ao método grego tradicional. Caso não se consiga visualiza lugares conhecidos para o loci, pode-se criar lugares fictícios, contanto que eles sejam potentes para fixação na mente.

Se compreendermos a mnemotécnica do Ad Herennium como uma teoria da articulação das idéias e da formação do pensamento via construção da linguagem, notamos que a possibilidade de criação de loci fictícios abre caminho para uma multiplicidade de associações que supera os critérios de velocidade e denotação demandados pela oratória, e pressiona novamente o estudo da memória como arte para além da mnemotécnica retórica. Notaremos, mais adiante, no pensamento de Cícero, os desdobramentos de tal questão.

O estudo da memória no tratado contém alguns indicadores peculiares da formação do homem antigo, que se revelam na maneira curiosa como o método foi estruturado. É difícil para o homem contemporâneo imaginar a prática de um sistema que exige o trabalho tão exaustivo sobre a visualização dos elementos.

${ }^{21}$ Op. cit., p. 8. 
Chama a atenção o enorme valor que a visão tinha no período, que, no sistema, se manifesta pela definição extremamente rigorosa das qualidades dos loci

Sob esse aspecto, o autor estabelece, ainda, claramente, a diferença entre a memória para as coisas e a memória para as palavras. A memória das coisas se utiliza mais livremente das associações conforme foram apresentadas até aqui, pois as coisas são exatamente os assuntos/conteúdos do discurso. A memória das palavras prevê a visualização de um loci para cada palavra, e o movimento mais dinâmico entre eles, além da possibilidade de se estabelecer a associação com o loci pelas referências sonoras. Outro recurso seria construir os loci seguindo o modelo da taquigrafia, como uma unidade para cada símbolo, prática que o autor desaprova. De fato, ele não reconhece a mesma aplicabilidade nem valor nas duas memórias, pois a segunda é consideravelmente mais trabalhosa e especializada, ainda mais se imaginarmos o tamanho dos discursos do período. A memória das coisas é mais útil, e por ela a outra pode também ser aprimorada sem a necessidade de treinamento tão específico. Na antigüidade latina, a primeira foi denominada de memoria rerum, e a última, dememoria verborum.

O Ad Herennium é o mais importante documento sobre a arte da memória que nos chegou dos antigos. Toda ciência e filosofia subseqüente irão basear- se em seus apontamentos sobre a cartografia da memória, memorização de coisas e palavras e associação para daí avançar. Grande parte de sua importância, como já vimos, reside no rigor com que o autor conduz sua análise, que extravasa a problemática específica da mnemotécnica para investigar a formação das imagens da mente, questão que envolve e estimula uma reflexão mais ampla sobre as complexidades na formação do pensamento. Mas não só: nesse tratado, pela 
primeira vez se esclarecem, no pensamento antigo, as demandas criativas do sistema dos locais.

O espírito se movimenta pelos loci não apenas para memorizar trechos de um discurso, mas para conectar blocos de conhecimento dos quais ele precisa dispor, e para isso, desenvolve critérios particulares de associação. Alguns obedecem aos cânones do imaginário coletivo, mas o método não restringe a navegação a associações de tal natureza. Pelo contrário, o autor indica que até mesmo locais fictícios podem ser criados, contanto que imprimam com potência o loci na mente. Portanto, não é exagerado afirmar que a viagem da alma pelos "locais da memória" não é um processo meramente associativo, mas criativo. Ou melhor, a associação é, em si, um processo de criação de sentidos.

Notemos como o autor avança nessa abordagem quando trata das qualidades inatas do memorável e desenvolve uma linha de argumentação que não está na arte da memória tradicional grega, reforçando a hipótese da composição criativa dos loci e de suas imagens residentes:

\footnotetext{
"Agora, a natureza mesmo nos ensina o que fazer. Se vemos no nosso dia-a-dia coisas que são insignificantes, comuns e banais, nós geralmente não conseguimos nos lembrar delas, por que a mente não foi comovida por algo novo e interessante. Mas, se vemos algo inferior, desonroso, não-usual, grande, inacreditável ou ridículo, nós nos lembraremos facilmente por muito tempo. Da mesma forma, esquecemos das coisas que estão imediatamente diante de nosso olhos, enquanto lembramos melhor de incidentes da nossa infância. Isso não se dá por outro motivo senão que as cisas comuns escorregam facilmente da memória, enquanto aquelas mais impactantes e novas permanecem mais tempo na mente. [...] Se selecionamos imagens que não são muito vagas e comuns, mas ativas (imagine agentes), se atribuímos a elas uma beleza excepcional ou uma feiúra singular [...] ou atribuímos certos efeitos cômicos a suas imagens, por isso, também, lembraremos delas mais prontamente. 22
}

${ }^{22}$ Ad Herennium in op. cit., p. 10. Grifos meus. 
As imagine agentes são exatamente as imagens trabalhadas pela imaginação ${ }^{23}$ (figments) para adquirirem características mais fortes, e assim se imprimirem com mais eficiência na memória. Estas são as imagens potentes para a memorização, e não quaisquer imagens recolhidas da percepção cotidiana. Não são imagens comuns apreendidas da natureza pelos sentidos, são imagens transfiguradas pela criação.

O autor ressalta o caráter ativo de tal operação, que consiste exatamente na criação de algo novo sobre uma imagem banal para diferenciá-la. Esse processo demanda encontrar para tais imagens qualidades que as descolem da condição cotidiana: deformá-las, transformá-las, colori-las, aumentá-las, diminuŕlas, enfim, “artificializá-las" criativamente pela atribuição de qualidades completamente dissociadas ou pela dilatação ou redução daquelas já existentes. Chegamos ao ponto em que, verdadeiramente, a memória se assume como arte.

Eis por onde o Ad Herennium acrescenta algo fundamental à mnemotécnica grega que lhe serviu de base. O sistema dos locais da memória admite, ou mais, exige a criação das imagine agente, e tal produção não resulta apenas da associação na concepção clássica (denotativa), mas da criação sobre as imagens cotidianas. Por isso é uma arte, e não uma mnemotécnica instrumental, ou, mesmo quando serve de instrumento da oratória, tem, intrínseca à sua natureza processual, a criação.

À mesma época do Ad Herennium, Cícero concebia seu De inventione. Nesse tratado, ele não acrescenta muito às bases técnicas da arte da memória, mas estabelece conexões entre memória artificial e virtude que influenciarão

\footnotetext{
${ }^{23}$ Lembremos que desde Aristóteles a imaginação e a memória pertencem à mesma parte da alma.
} 
profundamente a filosofia da memória no período seguinte. Ao final do De inventione (que se refere exclusivamente ao estudo da primeira parte da retórica, inventio), Cícero define as quatro partes da virtude: a prudência, a justiça, a fortaleza e a temperança, cada uma se subdividindo em outras virtudes derivadas e contíguas. A memória aparece como uma das forças virtuosas subjacentes à prudência:

\begin{abstract}
“Prudência é o conhecimento do que é bom, do que é ruim, e do que não é nem bom nem ruim. Suas partes são: a memória, a inteligência e a providência (memória, intelligentia, providentia ). Memória é a faculdade pela qual a mente recorda o que aconteceu. Inteligência é a faculdade pela qual verificamos o que existe. Providência é a faculdade pela qual prevemos que alguma coisa vai acontecer antes que ela ocorra." 24
\end{abstract}

Trinta aos mais tarde, quando escreve o De oratore, os princípios da mnemotécnica do Ad Herennium já estão amplamente difundidos e formam a base do ensino nas escolas de oratória latinas. Evidentemente, eles já foram assimilados pelo maior orador do período que, na sua obra mais significativa para o estudo da ars memorativa, retoma rapidamente a análise das imagine agentes conforme já apresentada no Ad Herennium e utiliza uma nova terminologia para definir o jogo das impressões: a máscara. O Ad Herennium está como o principal sistema criativo de formação de imagens da época, que transforma as apresentações dos oradores e em verdadeiros acontecimentos artísticos, dada a riqueza de sua expressão.

Como orador, está claro que, dentro do estudo da mnemônica, interessava a Cícero, particularmente, também a memória das palavras e os procedimentos específicos para seu aprimoramento. Não há divergência sobre os princípios

${ }^{24}$ Op. cit., p. 20. 
apresentados no tratado anterior e sobre a função da arte da memória nos estudos da oratória, e Cícero vai ao encontro do autor do Ad Herennium quando logo reconhece que a memória das coisas trabalha a mente de maneira mais abrangente, e que a memória das palavras exige uma multiplicidade exaustiva de combinações e de associações com os loci às vezes conflitantes. Em De oratore, Cícero, permanecendo fiel ao sistema dos locais do Ad Herennium, posiciona a arte da memória criadora do sistema dos locais como um dos atributos essenciais da ars oratoria no quadro geral da cultura latina emergente, inaugurando uma fusão de campos que irá marcar toda tradição de estudo da memória atéo fim do medievo

Para caracterizar as representações que se articulam na composição dos lugares e na ocupação das imagens, ele apresenta o termo máscaras: “... a memória das coisas é uma propriedade especial do orador - e nós podemos imprimi las nas nossas mentes por um arranjo habilidoso de diversas máscaras (singulis personis) que as representam, assim que podemos compreender as idéias pelos sentidos das imagens e a sua ordem pelos sentidos dos locais."25

A noção de máscara é a princípio muito interessante, e poderia indicar uma revisão da teoria que contemplasse mais profundamente os processos afetivos na dinâmica de associação dos loci. Mas essa abordagem não é assumida nem desenvolvida pelo autor, apenas sugerida pelo uso de uma nova expressão.

Um século após a apresentação do Deoratore, é produzido o terceiro cânone da arte da memória da antigüidade, o Institutio oratoria, de autoria do então principal professor de retórica do Império Romano no século I a.c.: Quintiliano. Na obra, Quintiliano revisa o De oratore ciceroneano para apresentar uma crítica, ora

${ }^{25}$ Op. cit. p. 18. 
concessiva, ora feroz , da memória artificial, e indica que os princípios de sua arte da memória já tinham oponentes entre os pedagogos e filósofos da época. Contra a divisão da oratória em cinco partes definida por Cícero, Quintiliano propunha uma divisão em três partes, em quememoria e actio (ação) seriam atributos dados pela natureza, não pela arte.

No Institutio oratoria, a análise que Quintiliano desenvolve sobre a construção dos loci deixa de lado a abordagem imaginativa e criativa do Ad Herennium e do De oratore para buscar na própria percepção os critérios de associação. Para nosso estudo, revela uma corrente conservadora dentre os estudiosos da mnemônica no que diz respeito à natureza criadora de tal função, assumida e desenvolvida no Ad Herennium.

Para ele, osistema dos locais da memória funciona não por que precisemos atribuir sentidos imaginários para cada loci fictício, forçando relações entre os sentidos dos trechos do discurso ou das palavras e as imagens dos locais construídos. Ele é útil simplesmente porque quando vamos a um lugar qualquer e depois o visitamos novamente, naturalmente vem à mente não apenas a aparência do local e seus detalhes como também as emoções que experimentamos em cada passagem pelo lugar:

\footnotetext{
"O sucesso de Simônides parece fazer emergir a observação de que é de ajuda para a memória se locais forem marcados na mente, fato que qualquer um pode comprovar da experiência. Quando voltamos a um local depois de uma considerável ausência, nós não apenas reconhecemos o próprio lugar, mas lembramos de coisas que fizemos ali, pessoas que encontramos lá e até mesmo pensamentos que passaram pela nossa cabeça quando estivemos lá antes. Assim, como na maioria dos casos, a arte se origina da experiência." 26
}

\footnotetext{
${ }^{26}$ Intitutio oratoria in Op. cit., p. 22.
} 
Eis a faculdade que, para o orador de Roma, opera efetivamente sobre a memória: a percepção. A associação entre os locais e os conteúdos a serem memorizados deve se dar da maneira mais natural possível, conforme acontece imediatamente na vida quando estamos em algum lugar. Para ilustrar a abordagem, ele cita o exemplo da arma e da âncora como locais para guardar parte de um poema ou discurso que trate da guerra e da navegação.

Sobre a disposição das imagens, Quintiliano parece preferir o método arquitetônico de Aristóteles ao sistema cartográfico e alegórico do Ad Herennium, e sugere a formação de um edifício como melhor disposição dos loci. Esse edifício pode ser enriquecido com salas, corredores, quadros, estátuas e demais objetos que funcionem como modelos imagéticos para representações diversas, e assim multiplicar e facilitar as associações. A precisão na visualização dos locais também e retificada pelo autor, pois a maior definição das imagens na mente as reaproxima da experiência da qual se originaram, e torna o processo mais eficiente.

Nesse sentido, a arte da memória de Quintiliano difere diametralmente daquela de Cícero e do Ad Herennium em um aspecto pedagógico de grande importância: o tratamento das imagens memoráveis. Se para os primeiros, as imagens que se fixam na memória são exatamente as imagines agentes, a figura dilatada, deformada, trabalhada pela imaginação para se distinguir das imagens cotidianas, a mnemônica de Quintiliano atesta precisamente o oposto: as imagens da percepção são mais rapidamente identificáveis e memoráveis, ainda que se possa utilizar das imagens criativas em alguns casos específicos.

O processo de associação de conteúdos de vivência e locais já acontece na experiência diária, e uma arte da memória que se pretenda eficiente deve 
estabelecer seus princípios técnicos a partir dessa dinâmica natural. A natureza já ofereceu o modelo por onde o processo mnemônico se realiza, e não é necessário que se criem procedimentos artificiais fantasiosos para acelerá-lo, a menos que partam do trabalho sobre a memória na forma como ela opera naturalmente na experiência, é o que nos afirma o autor em sua perspectiva racionalista.

Eis porque sua crítica mais feroz recai sobre o uso da mnemotécnica para fixação de palavras. A memória artificial para coisas pode até ser uma ferramenta para decorar a disposição espacial dos objetos em todo tipo de atividade da vida útil, e para tanto ele dá o exemplo dos leiloeiros que depois de encerrados os lances precisam conferir quais materiais venderam e para quem. Mas para as palavras, a associação com imagens mostra- se um recurso limitado.

Os argumentos de Quintiliano são consistentes quando levantam a problemática do fluxo das idéias. Não parece tão trabalhoso estabelecer um loci para cada palavra, mas quando temos trechos de palavras associados em um discurso que tem sentido específico, como criar locais para cada uma delas, sendo que algumas sequer sugerem representação visual possível, como as conjunções? Lembremos que nosso autor não privilegia a imaginação, e restringe as imagens aos conteúdos da percepção, ou seja, às imagens mais idênticas àquelas da natureza, diminuindo consideravelmente as possibilidades de representação: “Como podemos esperar que nossas palavras encontrem o fluxo de conexão do discurso se temos que olhar para trás em formas separadas para cada palavra individualmente?”27

${ }^{27}$ Op. cit., p. 24. 
Como alternativa, o orador sugere um sistema mais simples e racional para memorização das palavras. Ele toma a técnica dos tabletes de cera como ferramenta principal para criar uma arte da memória mais próxima do que atualmente chamamos "decorar"28. Os discursos são marcados mais fortemente com alguma imagem associada do pensamento nas passagens de difícil memorização, mas a maior parte da obra deve ser lembrada “de coração", ou seja, decorada após intensa leitura e repetição.

É possível utilizar um loci para essas passagens, mas é mais eficiente associar aos loci o próprio trecho do discurso como foi concebido, partindo da visualização do texto, das linhas das palavras, e não da criação de uma série de referências que criam uma cadeia muito extensa de associações. Mais produtivo ainda, e nisso consiste efetivamente o método do orador romano, é memorizar o próprio texto diretamente na mente, suas páginas, sua escrita, da maneira como a experiência o definiu, pontuando-se com imagens exteriores apenas os momentos mais fugidios. Em última instância, o bom orador é aquele que apreende o texto instintivamente, pelo coração e alma: as vias da natureza, e não depende de "truques" para realizar seu trabalho.

O método de Quintiliano é o contraponto racionalista ao sistema imaginativo anterior da arte da memória. Se a tradição grega exige a separação entre as imagens da percepção e as imagens da memória para explicar como o conhecimento sensível se transforma para efetuar as operações da mente, o pensamento de Quintiliano parte da representação da natureza sintetizada pelas

\footnotetext{
${ }^{28} \mathrm{O}$ duplo sentido da expressão como chegou até nós reforça exatamente a natureza extrínseca, pouco criativa e "decorativa" que a arte da memória adquire quando trabalhada nesses termos.
} 
imagens da percepção para encontrar os mecanismo mais imediatos de construção de sentidos na associação necessária para se re-evocar os conteúdos. A abstração criativa das imagines agentes dá lugar à impressão direta e mimética dos materiais: as páginas do texto, suas linhas, as particularidades da escrita, etc. Aqui, a linguagem das pinturas mentais e do depoimento de imagens, necessário para o sucesso da aplicação do sistema na mente, adquire tons mais realistas e miméticos.

Estes são as chamadas três fontes originais da arte da memória que ultrapassam a antigüidade e formam o cânone do estudo da mnemônica como chega à Idade Média. Se em certos momentos tratamos da mnemônica como arte da memória, termo que, já esclarecemos, é realmente mais apropriado, e em outros resgatamos a noção mais simplista a que remete a expressão mnemotécnica é porque desde a metafísica platônica até a apropriação de tal arte pela oratória latina, seu âmbito ontológico se diluiu; e, com Quintiliano, o peso da instrumentalização impõe-lhe novas fronteiras eatribuições, mais adequadas à arte oratória emergente.

A passagem para o pensamento medieval marca um novo tratamento da memória na formação do espírito, agora atrelado profundamente às questões da moralidade do indivíduo conforme os ditames do Cristianismo. Lembremos que desde o De inventione, a memória está como um ramo da Prudência, que pela doutrina cristã medieval emergente deixa de ser uma parte da virtude para se elevar como uma das quatro virtudes cardeais (as outras partes também ganham tratamento de virtudes autônomas, e não mais um "pedaço" da uma virtude maior abstrata). Esse detalhe é importante se compreendermos que nele se revela o crescente movimento de construção dos dogmas do pensamento medieval, pelos 
quais, mais tarde, seriam possíveis julgar todos os comportamento do período, a devoção, a heresia, os crimes, etc.

O principal relato sobre esse período intermediário está nas Confissões de Santo Agostinho, em que o autor narra sua trajetória de conversão. Nele, se misturam as imagens dos sentidos e as imagines agentes mantendo-se a premissa da distorção como base para estabelecer o memorável: Eu ando pelos campos e palácios espaçosos da memória, onde estão os tesouros de inumeráveis imagens, trazidas de todo tipo de coisas percebidas pelos sentidos. Elas estão marcadas, além do que pensamos, tanto ao aumentarmos quanto ao diminuirmos, ou variando em qualquer outra maneira que tenham aparecido a nossos sentidos $[\ldots] .29$

O cristianismo agostiniano é de forte influência platônica, o que determina uma localização particular para a memória na doutrina das virtudes. Quando trata a faculdade como manifestação de inteligência divina, ele vê nas imagens memoráveis a fonte do saber verdadeiro, porém não ligado a uma existência anterior do indivíduo, conforme a teoria Platônica, o que seria inconcebível para o pensamento cristão, mas como a expressão mesma do Uno que permanece em todos os homens enquanto sua criação. Em outras palavras, a memória é o conhecimento inato que parte de Deus e descende aos homens no instante de seu nascimento para que por ela possam desenvolver as virtudes do espírito. Tamanho é seu papel no encaminhamento correto da atividade espiritual, que ele a situa como um dos três poderes da alma, cujos outros dois são o entendimento e a vontade, e que juntos são a imagem da santíssima trindade no homem.

${ }^{29}$ Confissões, $X, 8$ in op. cit., p. 46 
Essa abordagem tem como desdobramento natural uma utilização da memória como caminho para se encontrar a Deus, ou seja, o divino enquanto entidade e estatuto moral e transcendente é o conteúdo absoluto a que todas as imagens da memória devem denotar. Eis de onde vem a onipresente representação dos vícios e virtudes pelas artes plásticas do período. O homem medieval será forçado a buscar incessantemente representações para as qualidades ou desvios morais de sua época, pois a salvação do espírito mediante uma memória virtuosa tornava se questão de vida ou morte.

Santo Agostinho morre no auge das invasões bárbaras que marcaram a derrocada do Império Romano. A apropriação da arte da memória pela doutrina cristã que marca sua obra ocorre simultaneamente à intensa divulgação do Ad Herennium por todos os principais círculos de oradores cristãos e pagãos do já esfacelado império. A arte da memória sobrevive à hecatombe cultural em grande parte dado à preservação do antigo sistema educacional das sete artes liberais (retórica, gramática, dialética, aritmética, geometria, música e astronomia), que chega ao medievo como o paradigma institucional de educação do cidadão.

Entretanto, as origens de cada tratado específico, e mesmo seus conteúdos, acabam por confundir-se ao longo dos anos pela intensa e indiscriminada disseminação que marca as transfusões culturais do período. A tal ponto que o mais importante documento da retórica medieval é uma suposta Primeira e Segunda Retórica (ou Velha e Nova Retórica), de autoria de "Túlio" que, mais tarde, se descobriria tratar-se respectivamente do De inventione e do Ad Herennium. Tal fonte será a principal base de informações para toda reflexão sobre o assunto na escolástica, paralelo ao obscurecimento do modelo de Quintiliano. 
De toda forma, essa virada moralizante marca uma nova etapa no estudo da arte da memória, a que a pesquisadora Frances Yates classifica como a transformação medieval da arte clássica. O tratamento da memória direciona-se para as questões da salvação e da danação da alma, e põe-se a serviço de encontrar as imagens que ilustrem os mistérios da fé e da heresia. Ou seja, migra gradativamente da retórica para a ética. No âmbito das técnicas, o sistema dos locais perdia popularidade para a memorização pela repetição da escrita, que alimentava uma abordagem mística da fixação dos conteúdos, (ao gosto de Quintiliano e sua memorização 'de coração', paradoxalmente) e acentuava a noção agostiniana de memória como manifestação do criador. O pensamento medieval nasce dessa tensão entre uma idéia de memória como inspiração divina (e, portanto, natural, impossível de ser tocada pelos artifícios das mnemotécnicas) e o legado pedagógico fantasioso do Ad Herennium, agora apresentado como Segunda Retórica de Túlio.

Será entre os dominicanos que a escolástica produzirá os filósofos mais expressivos sobre a arte da memória. Seu pensamento irrompe de uma intensa retomada da teoria antiga como resposta à corrente revisionista mais dura que dissociava a memória da Prudência para relacioná-la aos atributos inferiores da alma. Assim, boa parte dos estudos dominicanos consistirá em encontrar as explicações metafísicas que justifiquem a natureza da memória como parte da Prudência, e num sentido mais amplo, ainda como mecanismo para o exercício das virtudes.

Alberto Magno e Tomás de Aquino são os nomes mais significativos nesse sentido. Alberto Magnos produziu seu tratado De bono especificamente para o 
estudo das quatro virtudes cardeais. No capítulo sobre a Prudência, ele responde aos principais argumentos que atestam o não-pertencimento da memória a tal virtude, os quais são:

1) A memória pertence à esfera sensitiva do espírito, enquanto a Prudência pertence à parte racional.

2) A memória como lembrança de impressões passadas não é um hábito, e a Prudência é um hábito.

O autor recorre a Aristóteles para encontrar suas justificativas: conforme o filósofo, a reminiscência é a parte racional da memória, e é esta que pertence à virtude, da mesma forma como pode se tornar um hábito, pois permite recordar experiências do passado e sugerir atitudes prudentes para o presente e uma visão prudente para o futuro. A memória como reminiscência gera aprendizado, e, portanto, é parte do cultivo da Prudência, e sua técnica deve ser estimulada. Estabelecendo uma ponte curiosa de Aristóteles com o Ad Herennium, vai mais além e sugere que a reminiscência é a própria memória artificial, diferentemente da memória comum, domínio da parte sensitiva da alma.

Essa distinção é marcante na teoria da memória de Magno, que contrasta com a orientação hegemônica sobre os lugares da memória do período. A poesia e a fantasia foram delegadas aos graus mais baixos da atividade humana pelo rigor racionalista e pelo puritanismo da escolástica, de onde se conclui a ousadia do autor ao sugerir as imagines agentes como as imagens do conhecimento na memória. Os sistemas mais aceitos eram aqueles que se utilizavam de imagens 
mais próximas do real para a construção dos loci, o que, de fato, Magno parece a princípio também concordar.

Mas, quando funde as imagens artificiais conforme o modelo da Segunda Retórica (o Ad Herennium) com as imagens de conhecimento da reminiscência aristotélica, cria um paradoxo de difícil aceitação para a tradição filosófica de seu tempo, pois admite que ainda que as imagens que denotam ao real sensível (propria) representem melhor seu objeto, as metáforas (metaforica) "movimentam a alma de maneira a auxiliar melhor a memória."30 Assim, as metaforicas, outrora imagines agentes, os produtos específicos da memória criadora, são os elementos naturalmente mais adequados para se chegar às proprias.

Para sustentar sua hipótese, Magno não poderia recorrer a outro senão a Aristóteles pra explicar como as impressões são transformadas de sensu communi até se tornarem memoria em diversos níveis de desmaterialização. Os fatos passam pelas sucessivas faculdades pertencentes à parte sensitiva da alma até atingirem o intelecto, sem perder totalmente suas qualidades corporais, mas alterando sua imagem, até restarem como reminiscência no espírito. Eis por onde se justificam ao mesmo tempo a existência virtuosa das imagine agentes/metaforica e a necessidade igualmente virtuosa de uma arte da memória a serviço da Prudência.

O tratado de Alberto Magno busca compreender o funcionamento da memória preservando os conhecimentos que chegaram dos antigos em uma época em que todo estudo estava fortemente cerceado e coagido pelo patrulhamento moral do Estado Clerical. Sua devoção a Aristóteles e a seu conhecimento baseado

${ }^{30}$ Op. cit., p. 65. 
na observação da natureza protege, mesmo sem essa intenção, a arte da memória da perseguição ideológica e cultural que rondava todo atributo relacionado ao corpo, de onde a associação com a Prudência surge mesmo como um escudo contra seu banimento para o âmbito dos vícios do corpo. A defesa da fantasia não era pouco em uma época em que as únicas representações legítimas denotavam ao Céu e ao Inferno, e deveriam ilustrar/alertar sobre os destinos do homem que se dirige por um caminho ou por outro.

A memória não sobreviveria enquanto arte se não se adequasse às exigências da doutrinação cristã. A busca por representações no medievo tratava fundamentalmente de encontrar imagens para os vícios e virtudes e para as figuras da Bíblia que se imprimissem de tal forma nos espíritos a ponto de não deixar nenhuma dúvida sobre os terrores da danação para os pecadores e da glória para os fiéis. De onde Magno traz o conceito de intentione para a memória, ou seja, cada imagem memorável carrega não apenas a representação do objeto, mas as emoções e sensações afetivas que objeto é capaz de gerar. Cada imagem é parte de um vocabulário sutil para catequização e doutrinação pela memorização dos dogmas e das punições que advém de seu desrespeito.

O outro grande tratado medieval que relaciona a memória à Prudência é o Summa Theologiae, de São Tomás de Aquino. Como Alberto Magno, ele também se ampara na teoria aristotélica para explicar a participação da memória na Prudência (estabelecida há tantos séculos por Cícero), cuja defesa é, em última instância, uma resistência do conhecimento frente à máquina teológica através da apropriação moderada de certos conceitos. Entender a memória pela ótica do Cristianismo, 
nesse contexto, permitiu com que ela continuasse existindo, de alguma forma, como objeto de estudo dos escolásticos.

Não há atividade intelectual sem a formação das phantasmata. A imagem é a representação corporal das coisas em si, é a percepção do individual. A partir da percepção dos individuais é possível extrair o universal, e, assim, chegar ao entendimento. Nesse processo, ao contrário do primeiro pensador, ele não procura na reminiscência a justificativa para tal conexão.

Para Aquino, as imagens que melhor se fixam na memória são exatamente as mais brutas e próximas da percepção sensível. Os critérios de associação e sua eficiência dizem respeito aos graus de ordem e não de fantasia da memória, numa abordagem mais racionalista do que aquela de seu colega dominicano. A memória é arte da Prudência não porque é reminiscência e, portanto, parte da racionalidade humana. Ao contrário, Aquino afirma que a memória pertence à parte sensitiva da alma, mas a Prudência, quando se utiliza da análise dos individuais para extrair o universal, contém em si muito da parte sensitiva da alma, e a memória é uma dessas partes. Da mesma forma, a Prudência, também tem inicialmente uma dimensão natural que pode ser dilatada pelo exercício da virtude, assim como a memória. Ambas podem ser ampliadas artificialmente. E, seu último argumento, semelhante a Magno: se a Prudência se utiliza da experiência para prever e alterar o futuro, da mesma forma procede a memória. Não há nada que contradiga a memória como virtude.

Quanto ao tipo de imagem, Aquino apresenta um paradoxo curioso. Seguindo toda tradição do Ad Herennium, ele admite que memorizamos mais facilmente as imagens que não se assemelham diretamente ao real, e sim aquelas 
que possuem alguma distorção. Mas, ao mesmo tempo, como já dissemos, importa de Aristóteles a hipótese de que o espírito fixa melhor as imagens mais "brutas", ou seja, mais próximas do sensível, enquanto as imagens mais sutis e espirituais escapam da alma. De onde ele sugere que se criem "similitudes corporais" para as imagens a fim de aproximá-las do sensível. Esses locais assemelhados ao real devem ser organizados com rigorosa disposição conforme os critérios de distanciamento e disposição do place-system aristotélico, pois de tal ordem depende a qualidade de associação.

Vemos, então, que o sistema dos locais antigo sofre algumas alterações bastante profundas pelo pensamento escolástico em seu esforço de moralização, adquirindo um caráter eminentemente místico e de devoção apesar de recorrer insistentemente a Aristóteles. A releitura da teoria aristotélica está de tal forma contaminada pelas demandas ideológicas da doutrina cristã que se deve pensar menos em termos de um verdadeiro embate filosófico do passado e presente sobre a memória e mais na urgência em se encontrar argumentos que respondam às possíveis heresias sobre o assunto. De toda forma, é como parte da Prudência, lembrança do bem e do mal que fornece exemplos para o comportamento correto baseado no cultivo das virtudes e no afastamento dos vícios pela fé, que a memória é absorvida pela rigorosa ética do Cristianismo medieval.

A transformação medieval da arte clássica, a que Yates se referiu, representa não somente um reposicionamento da memória quanto ao âmbito de estudo, mas uma revisão também de sua utilização como arte (a serviço de que[m]). Se na oratória antiga os recursos mnemotécnicos estavam a disposição do orador e do poeta, na passagem para a Idade Média a voz que enuncia fala invariavelmente em 
louvor ao Deus cristão e a seu estatuto moral. Portanto, a oratória se transmuta basicamente na arte de memorizar sermões, e deve movimentar o espírito para mais perto do criador. Eis porque ela só pode sobreviver como ramo da Prudência, porque se for dissociada da virtude e se tornar uma faculdade amoral, poderá facilmente servir aos vícios, e, portanto, sua existência e seu estudo serão inaceitáveis.

A natureza das "coisas" que devem ser memorizadas pelos padres para seus sermões diz respeito exatamente aos artigos da fé, com grande ênfase nos efeitos que sofre aquele que não segue seus preceitos, bem como nas recompensas dadas ao fiel. A herança de Tomás de Aquino nesse sentido é enorme. Sua premissa de que tudo que é sutil e espiritual escapa mais facilmente à alma e de que os locais das imagens necessitam muito mais de ordem do que de imaginação é elevada à máxima, e torna a busca por similitudes corporais uma característica fundamental da mnemotécnica dos sermões e da pregação do período.

Entretanto, essa procura por similitudes não resulta numa arte da memória mimética, como poderia se supor, mas exatamente o oposto: acentua o caráter subjetivo das imagens criadas, especialmente por que estas têm como função ilustrar as virtudes, os vícios e suas conseqüências. Em seu livro, Yates sugere uma conexão muito interessante e certamente pertinente, embora não tenha sido sistematicamente estudada, entre essa orientação do filósofo- orador escolástico e a enorme quantidade de representações humanas e semi-humanas para as virtudes e vícios presentes na arte gótica. As imagens góticas são essencialmente alegóricas, contém algo de humano, mas também de animal, distorcido, "enfeiado", ou excessivamente embelezado. Representam invariavelmente qualidades abstratas: 
os vícios ou as virtudes, os santos ou imagens de sábios, o céu, o inferno, o purgatório. São elas possíveis expressões artísticas das imagine agentes do Ad Herennium, das metaforicas de Magno?

Objetivamente, o avanço da escolástica marca a disseminação da arte da memória para além do âmbito das escolas, e, a partir do século XII, a mnemotécnica revista por Tomás de Aquino é assumida como instrumento de catequização, possível de ser experimentada por qualquer fiel em seu exercício da fé. Paralelamente, toda arte do período está alicerçada na mesma forma de representação das imagens utilizada pela arte da memória medieval, e torna impossível não se pensar na evolução da estética e da arte da memória em cooperação mesmo em um período que não privilegia tais associações. Pode a arte da memória, repleta de símbolos de pulsões, explicar o gosto pelo grotesco do homem medieval?

Yates cita as pinturas de Giotto e as descrições de Dante para o đ́u e o inferno como possíveis expressões pictóricas das imagines agentes da memória, e inúmeros outros quadros e afrescos como possíveis exemplos em que as figuras representadas estão, na verdade, compondo diferentes mapas de loci. É uma idéia instigante, que mereceria um estudo mais detalhado a respeito, e se comprovada, oferece uma perspectiva verdadeiramente reveladora e inovadora sobre a arte do período.

O advento da imprensa altera profundamente o desenvolvimento da arte da memória. Exteriormente, pois se multiplicam e disseminam com muito mais intensidade os tratados e todo tipo de reflexão a seu respeito. Internamente, e de forma mais crucial, porque torna questionável a função da memorização diante da 
reprodutibilidade mecânica. O primeiro tratado impresso sobre a memória é um esquema bastante semelhante aos círculos do céu, inferno e purgatório de Dante que apresenta uma série de esferas do universo em projeção transcendental como sistema de memória dos vícios e virtudes. Chamava se Oratoriae artis epitome, de autoria de J acobus Publicius, impresso em Veneza, em 1482.

O segundo texto impresso tornou seu criador muito mais famoso do que Publicius. Phoenix, sive artificiosa memoria, de Pietro de Ravenna foi lançado em 1491, e tornou-se o mais popular «crito sobre mnemotécnica da época, em parte graças à abordagem mais prática e didaticamente eficiente de seu autor. Fortemente influenciado pelo Institutio oratoria de Quintiliano, Pietro de Ravenna propunha um sistema de locais baseado na visualização real dos locais, e no preenchimento dos conteúdos na medida em que o orador passa por estes. É preciso realizar o processo por três ou quatro vezes, e depois, basta recordar o passeio para que as imagens das coisas e dos discursos relacionados a cada loci apareçam.

Porém, cabe aos dominicanos continuar na Renascença com a divulgação e investigação sobre a arte da memória iniciada séculos atrás por seus colegas Alberto Magno e Tomás de Aquino. Dois nomes marcam o estudo da arte da memória no período, cujas obras respectivamente abrem e fecham o século XVI: o alemão J ohannes Romberch e o fiorentino Cosmas Rosselius.

Congestorium artificiose memoriae, de Romberch, foi publicado em 1520, e se divide em quatro partes: a introdução, primeiro capítulo sobre os locais das imagens (ficta loca), segundo capítulo sobre as imagens em si e a quarta parte apresenta um esboço de seu sistema da memória. De fato, Roberch apresenta três 
modelos de sistemas. O primeiro utiliza o cosmos como mapa de locais num diagrama semelhante àquele de Publicius, em que cada ficta loca diz respeito a um lugar (céu, purgatório, inferno, nove ordens de anjos, estrelas, etc.) e deve ser ocupado por uma imagem referente a tal lugar.

O segundo modelo usa os símbolos do zodíaco como referência para uma memorização mais rápida dos locais, já que as imagens que representam os signos são amplamente conhecidas ${ }^{31}$. Para multiplicar os locais de tal sistema, ele sugere a inclusão das constelações celestes como possíveis mapas, se, no entanto, explicar como se associam os conteúdos a cada estrela.

E, por fim, o sistema mais comum, e muito parecido com aquele de Quintiliano e de Pietro de Ravenna, que sugere a memorização de lugares reais como residência dos conteúdos. Os objetos devem ser associados com cada parte da locação ou das locações visitadas de forma simples e denotativa. Uma curiosidade é que, nesse modelo que parte dos lugares reais visitados, adverte-se que não se deve escolher como loci um local que esteja fora do alcance do orador no instante da memorização.

Em 1579, Rosselius lança seu Thesaurus artificiosae memoriae, um sistema de forte teor dantesco, cujo diagrama divide o inferno em onze locais que formam o mapa de seu modelo. No centro está um poço cercado de degraus que se referem aos tipos de pecados conforme o grau de heresia. O paraíso tem no centro o trono de Cristo cercado de jóias, cujos lances em descendência distribui a hierarquia dos homens virtuosos: santos, virgens, patriarcas, sábios, etc. É o último tratado cristão

\footnotetext{
${ }^{31}$ Romberch foi, muito provavelmente, influenciado pelo diagrama zodiacal de Metrodorus de Scepsis, antigo poeta grego cuja capacidade de memorização tornou-lhe uma lenda entre os estudiosos da arte da memória, e que trabalhava a memória artificial por um sistema de locais de sua autoria, baseado nas imagens da Astrologia.
} 
de impacto numa cultura que avançava rapidamente rumo ao cientificismo, e que já não sustentava mais a coerção dos dogmas teológicos.

A derrocada do cristianismo, o avanço do humanismo e o advento da impressão atestam o fim da arte da memória como a conhecida até então. Evidentemente, ela participa de toda revolução das idéias que surge no período, e cujo apogeu se dará no Iluminismo. Com a evolução dos registros mecânicos, todos os sistemas complexos para memorização por lugares, com imagens sensoriais ou abstratas, locais verdadeiros ou fictícios, tornam-se obsoletos. A arte da memória sobrevive na Renascença apenas como assimilada pelo neoplatonismo, e retorna a sua função dentro das teorias mais amplas do pensamento. É por esse caminho, não mais como arte da oratória ou da ética, mas como processo de conhecimento em si que a memória chegará à filosofia moderna. 
Capítulo II - A memória na transição para o pensamento científico e filosófico moderno.

A separação entre as verdades da fé e as verdades da razão que marca a transição da Escolástica tardia para a Renascença representa, para o estudo da memória, um giro de perspectiva radical no que diz respeito ao seu lugar e função no novo projeto de humano que se criava. O desdobramento mais determinante, nesse sentido, e que irá reverberar no pensamento moderno, diz respeito à conseqüente primazia da razão sobre a fé no que tange à legitimidade do conhecimento. As verdades da razão, apoiadas pelas ciências exatas e humanas, tornavam- se mais consistentes que as verdades da fé.

Há, aqui, um salto considerável que necessita ser esclarecido para dimensionarmos as transformações pelas quais sofre o tratamento da memória no Renascimento e na modernidade. O cientificismo da Renascença apenas apontava as transformações no modus cogitare que seriam radicalizadas pelos pesquisadores modernos. Nesse primeiro período, o pensamento científico apenas inicia a caminhada em direção à forma de produzir e lidar com o conhecimento orientada para a especialização, baseada em pesquisas quantitativas e qualitativas e que busca verticalizar o olhar sobre as atividades humanas para destrinchar as especificidades de cada processo orgânico característica da modernidade. Os mistérios do corpo são a grande fronteira a ser "iluminada" pelo saber, e o aparato de observação, medição e investigação científicos aparecem como as ferramentas mais eficientes para realizar semelhante tarefa. 
A medida que tal perspectiva avança e se potencializa, o ideal do polímato renascentista, do homem que realiza diversas tarefas e, ainda que seja estudado com as luzes anatomistas da razão científica, é analisado como uma máquina cujas estruturas trabalham simultaneamente e conjuntamente, vai sendo naturalmente substituído por uma homem de funções específicas e especializadas: o homem moderno. Tal passagem transfigura completamente o estudo da memória, e de sua aplicação no campo das artes.

No capítulo anterior, vimos como se formou, no período antigo, o tratamento da memória como arte de criação e articulação de imagens; inicialmente, pelo sistema dos locais grego, que servia para a mnemo criação de quaisquer conteúdos, e foi plenamente absorvido e pela ars oratoria romana. Depois, analisamos como essa tradição sobreviveu às pressões culturais e ideológicas da Idade Média atrelada à Prudência, cujas linhas de força direcionam sua dinâmica de formação de imagens para o fantástico, o grotesco e a busca pelo sublime, estética de um imaginário coletivo assustado que ecoa em uma arte igualmente fantástica e visualmente impressionante.

Com o avanço do pensamento científico, o foco de interesse migra gradativamente das implicações transcendentais da memória para atingir a dimensão física que envolve sua produção, como de resto, sucede com os demais processos de funcionamento humano. A memória precisava ter seu âmbito de atuação enquanto faculdade arborescente claramente definido, separado, delimitado e esclarecido na nova anatomia de funções do ser racional, e, nessa partilha executada pela ciência dos primeiros anos da era moderna, coube-lhe, basicamente, a responsabilidade pela retenção. 
Duas diferentes "respostas" a essa problemática sobre os limites da memória e sua relação com a razão e a percepção surgem nas duas principais correntes do pensamento moderno emergente: o racionalismo e o empirismo. Em ambas, mas em cada uma à sua maneira, a memória estará, num primeiro momento, como um resíduo da realidade no espírito, uma faculdade menor que, pela existência do esquecimento, revela sua fragilidade para preservar as informações da percepção. Notemos que a memória nas ciências modernas dos primeiros anos, e na filosofia a elas atrelada, assume o antigo conceito de memória retentiva grego estabelecido por Platão, ignorando, no entanto, sua outra definição muito mais importante em sua teoria e mais avançada no esforço de dar conta das complexas associações de funções que participam das sínteses mnemônicas: a reminiscência.

O fenômeno da criação é um ainda mistério tanto para o racionalismo como para o empirismo. É necessário nomear outra faculdade, mais abstrata, misteriosa e afastada da percepção que justifique e credite a "confusa" atividade criadora: a imaginação. Estando a imaginação como a faculdade relativa à criação e a memória como faculdade "retentora" por natureza, com seus limites e atributos bem fixados, solucionariam-se as questões acerca tanto da invenção como da participação do corpo e da mente em tais processos. Porém, o desenvolvimento das artes vem mostrar que nem sempre estas operam no limite da loucura, e vêm questionar o papel da percepção na fantasia.

O depoimento pessoal no início da modernidade flutua nessa problemática que envolve memória e criação. A imaginação surge como a faculdade que isola a memória das dinâmicas de criação, mas, ao mesmo tempo, não tem sua operacionalidade satisfatoriamente destrinchada por nenhuma das duas correntes 
científico-filosófica que apontamos (provavelmente, porque um olhar mais aprofundado sobre seus atributos impusesse a revisão do âmbito de participação da memória para além da retenção).

Por outro lado, é do embate entre as faculdades como fixadas nesse período, e nas limitações teóricas daí decorrentes, que pudemos evoluir rumo a uma abordagem convergente para os estudos da memória, da percepção, da criação e da cognição. As funções são, sim, heterogêneas, e nisso tais cientistas não se enganaram. As linhas de força culturais do período pressionavam para a especialização como caminho mais provável para se aprender mais profundamente tais funções da mente, da qual, atualmente, já podemos nos libertar para buscar uma visão mais completa dos deslocamentos internos e externos do homem na construção dos saberes.

Nesse sentido, podemos dizer que a natureza criadora da memória não deixou de contra pressionar as atribuições a ela destinadas pelo pensamento moderno, abalando a noção de imaginação e percepção como faculdades isoladas. De fato, é a memória como criação que exatamente mistura os elementos das duas funções através de suas combinações. Não é de se estranhar que tantos artistas tenham sido enquadrados como doentes mentais nesse período, já que seus depoimentos pessoais provocam profundamente o rígido estatuto moderno da mente especializada. Suas biografias fornecem os relatos mais contundentes sobe a inadequação de sua arte ao pensamento vigente, em grande parte, exatamente pela liberdade em misturar fatos “da vida” com recriações fantásticas. 
Em seu Discurso sobre o Método, Descartes cita a memória em apenas um pequeno trecho da Quinta Parte ${ }^{2}$, logo após o minucioso discorrer sobre o funcionamento do coração, da circulação e da anatomia dos órgãos internos nos animais. Essa passagem é particularmente importante, pois, embora esteja deslocada do capítulo específico sobre a metafísica ${ }^{33}$, contém seus principais argumentos organicistas sobre os movimentos da alma na formação dos espíritos animais, que, em suas palavras, funciona como "um vento muito sutil (...) ou melhor, uma chama muito pura e viva”34 emanada do coração para o cérebro e que de lá chega aos músculos através dos nervos para realizar o movimentos.

A memória é apresentada em sua natureza retentiva, sem que se assuma mais detalhadamente o grau de conexão com a percepção, por meio do qual poderíamos afirmar ou não a retomada da perspectiva da falibilidade da lembrança como resultante da fragilidade dos sentidos (corpo). Essa dúvida se esclarece em seu tratado sobre as idéias, Meditações Metafísicas $^{35}$, onde a participação da memória na produção das idéias fictícias não deixa margem a especulações 36 . A memória está stuada como função periférica na gênese do entendimento, uma persistência das sensações que reside entre os saberes menos complexos, e cuja função na aquisição do conhecimento verdadeiro só é pertinente se submetida ao método, às operações da intuição intelectual.

No racionalismo cartesiano, sabemos da retomada cientificista do princípio escolástico que entende o corpo como moradia da alma, porém com relações de

\footnotetext{
${ }^{32}$ Intitulada "Ordem das Questões de Física".

${ }^{33}$ A Quarta Parte: "Razões que provam a existência de Deus e da alma humana ou fundamentos da Metafísica".

${ }^{34}$ Op. Cit., p. 100.

35 Por extenso, Meditaciones Metafísicas con objeciones y respuestas.

${ }^{36}$ Ainda que, como veremos mais adiante, ela tenha um papel importante na verificação do experimentado.
} 
identificação muito mais intensas do que de um simples comandar-obedecer. A influência do cristianismo ainda reverbera num mecanicismo temeroso, que ao mesmo tempo separa para efeito de pesquisa e reúne num contrato moral os estudos da fé e da razão para radicalizar o pragmatismo do poder divino sobre o homem pela exaltação da racionalidade. As relações entre as partes superiores e inferiores dos seres justificam a autonomia e indissolubilidade da alma e a dependência e divisibilidade do corpo, concentradas na máxima "Cogito ergo Sum"37.

A abordagem de Descartes sobre seus inúmeros experimentos em anatomia realizados no exílio, que poderiam lançar luz sobre a real cooperação entre os atributos da mente e os órgãos, se orienta para afirmar a hegemonia do núcleo cortical como organizador do pensar e cápsula da alma, que controla e direciona a atividade subjacente da res estensa. Nisso consiste boa parte da anatomia cartesiana: mapear e explicar a natureza dos movimentos que conectam os sistemas internos ao espírito (via cérebro), procedimento que está na base de criação do método e em sua aplicação no estudo da alma e da verdade.

Uma vez que somente na razão consiste a existência da alma (e, em última instância do ser humano verdadeiramente compreendido ${ }^{38}$ ), o método concentra quatro regras para verificar a irrefutabilidade dos fatos e daí sua metamorfose em conhecimento real, a saber:

\footnotetext{
${ }^{37}$ A expressão é comumente reconhecida por "Penso, logo existo". Porém, se remetermos à semântica original de "existir" como ex sistere, estar situado fora, parece-nos mais coerente ao pensamento do filósofo a tradução "Penso, logo sou." (algo ou alguma substância que mora dentro de [o corpo]). Na segunda meditação ("Meditacion Segunda, De la naturaleza del espíritu humano; y que es más fácil de conocer que el cuerpo"), Descartes reafirma o cogito em outra ordem para delimitação do humano: "[...] se estou persuadido de algo, ou meramente, se penso algo, é por que so u.”. Op. Cit. p. 24. Tradução minha.

${ }^{38}$ Os animais, evidentemente, não estão incluídos entre os seres animados a priori no discurso do método. Entretanto, Descartes, posteriormente, define a existência de uma "alma vegetante ou sensitiva" para explicar o comportamento sofisticado de certos animais e de doentes mentais.
} 
a) Regra da evidência: jamais aceitar como verdadeira alguma informação que não “conhecesse à evidência ${ }^{39 " . ~ E m ~ o u t r a s ~ p a l a v r a s, ~ q u e ~ n a ̃ o ~ t e n h a ~ s e ~ a p r e s e n t a d o ~}$ primeiro integralmente e incontestavelmente aos sentidos e à memória, que combina e atualiza as informações para afirmar ou negar seus conteúdos. Eis porque acreditamos que a percepção e a memória, ao contrário do que o filósofo insiste em fazer crer, não são funções suprimidas em termos absolutos da intelecção no método, pois elas estão entre as sínteses menores e primárias (a que Descartes chama "corpos, inteligências e naturezas imperfeitas"40) que preparam os materiais que serão verificados pela a razão. Ao procedimento operacional criado para sistematizar essa investigação sobre a veracidade do apreendido quanto a sua forma e conteúdo, causas e fontes, Descartes denominou dúvida metódica.

b) Regra da divisão (anatomia/taxidermia ${ }^{41}$ ): os problemas e dificuldades mais complexos que envolvem o conhecimento da realidade devem ser decompostos em parcelas mais simples tantas vezes quanto forem necessárias para sua resolução, estando cada nova parte suscetível à análise pela dúvida metódica.

c) Regra da ordem: os pensamentos devem ser distribuídos mentalmente em ordem de complexidade conforme o assunto e o grau de reflexão envolvido. Os conteúdos acessados pela percepção sensível estão entre os mais elementares, pois se situam no campo da observação e da impressão e não demandam sínteses

\footnotetext{
${ }^{39}$ Discurso sobre o Método. p.40.

${ }^{40}$ Op. Cit., p. 71. Em outra passagem ainda mais significativa da Meditacion Sexta (e última) De la existência de las cosas materiales, y de la distinción real del alma y el cuerpo, Descartes situa com ênfase o papel da memória numa etapa de pré-verificação sensível dos fatos que distingue os estados de sono e vigília: "[...] $Y$ no debo de modo algún dudar acerca de la verdad de esas cosas que, si, trás recurrir a todos mis sentidos, a mi memoria y a mi entendimiento para examinarlas, ninguna de esas facultades me dice nada que repugne a las demás. Pues, no siendo Dios falaz, se siegue necesariamente que no me engaña de eso". pp. 74-75.

${ }^{41}$ Parêntese meus.
} 
abstratas. No outro extremo, as operações matemáticas e todas atividades que envolvem o trabalho sobre a re elaboração das formas estão entre os mais elevados. d) Regra da enumeração: cada novo conhecimento exige a revisão completa das etapas que o produziram, a observação dos resultados em cada momento e a retomada dos procedimentos que o definiram, a fim de que o modelo metodológico em si, e não somente os conteúdos resultantes de sua aplicação, possa ser tomado como novo saber e reutilizado na medição e análise de outras experiências.

Da mesma forma, como negativo das leis, os erros que envolvem o encaminhamento da razão para definir a verdade se aglutinam em duas atitudes que Descartes classifica como "infantis", preconceitos enraizados na infância:

a) Precipitação: tendência em emitir juízos precoces, superficiais, imediatos sobre determinada questão antes da verificação racional (e aqui, a memória, junto com a imaginação, a que Descartes faz referências bem mais consistentes, e a percepção entra como os principais agentes de engodo).

b) Prevenção: submissão do espírito ao pensamento do outro, cristalização de conhecimentos socialmente afirmados por costumes, não por verificação, preconceitos, superstições, ilusões sustentadas pelo imaginário das sociedades.

O discurso do método, acima resumido, revela-nos queas idéias inatas são o único porto seguro, o reconhecimento do conteúdo divino descendente que se manifesta a todo o instantena razão, e cujo entendimento nunca é errôneo quando apreendido pelo processo apropriado. Todo equívoco na revelação do verdadeiro não poderá vir da falsidade das idéias naturais, pois são divinas e, portanto, sempre reais, mas de algum "ruído" nas etapas de investigação dos fatos. Diante desse dogma primeiro, Descartes divide as idéias humanas em três categorias: 
a) As idéias adventícias: idéias vindas de fora, das sensações, percepções e lembranças; as idéias da experiência e da lembrança das experiências com materiais externos. Produzem opiniões quase sempre enganosas (a doxa grega), especialmente quando não participam do raciocínio e da intuição, uma vez que está claro que a verdade está na razão do ser pensante, e não nos objetos como percebidos. Deduz-se que a lembrança acaba incorporada ao manto de imprecisão e desconfiança que ronda toda vivência da extensão na teoria. A memória coordena os materiais que geram as percepções enganosas com a mesma eficiência com que registra e combina as impressões verdadeiras.

b) As idéias fictícias: as idéias, imagens, figuras fantásticas que criamos em nossa imaginação em sono ou vigúlia. Aqui, a memória aparece assumidamente como fonte de enganação, uma vez que é através de seus conteúdos que o espírito acessa as informações experimentadas e imprimidas do real para recombiná-las, completá las anarquicamente na imaginação, criando objetos irreais. A memória é levada ao limite da imaginação, suas funções se misturam, e se acentua o antagonismo com a intelecção.

c) As idéias inatas: idéias colocadas por Deus no espírito humano e que estão na base do inatismo cartesiano como as únicas que denotam a verdade, a partir das quais é possível julgar a verdade ou a falsidade das outras. São inteiramente racionais e acessíveis pela intuição. A memória não participa de sua formação, pois é compreendida como acervo de impressões oriundas do aparato sensorial, e não das formas intelectuais. Não existe uma recordação para esses conhecimentos, como existia na doutrina platônica, mas sim uma fé consciente. 
Aqui, há de observar com atenção o papel da imaginação, uma vez que a proximidade de conceitos permite extrair algumas observações importantes para a noção de memória. Descartes classifica a imaginação como uma "peculiar tensão de ânimo"42, por meio da qual o ser pode admitir a propriedade do corpo pelo espírito. Está claro que o espírito não precisa do corpo para se definir em nenhum aspecto. Intelecção e imaginação são operações completamente autônomas, das quais, enquanto a primeira configura o ser em si, a segunda sequer atinge sua essência. Porém a imaginação existe 43 , e está próxima do ser; e se existe na acepção de verdadeiro como algo comprovado pela razão não pode ser ao mesmo tempo falso como não pertencente à criação divina. A imaginação, pois, é a função que permite ao espírito conceber o corpo. É através da força imaginativa que o ser consegue olhar o seu interior e formar imagens para as coisas corpóreas. É a capacidade interior de elaborar impressões sobre o corpo tomado como exterioridade.

Esse aspecto nos parece bastante significativo para o entendimento da memória também, pois relaciona as duas faculdades à capacidade de interpretação do homem sobre o corpo. Não nos interessa tanto, aqui, o âmbito das relações orgânicas, mas aquele da formação de imagens e das múltiplas associações e criações de sentido entre os materiais, fenômeno que dentro da metafísica cartesiana se afirma negativamente como engodo da racionalidade, mas que também pode ser compreendido como um adensamento de tudo que denota ao corporal e escapa à razão strictu sensu, a ser estudado pelas filosofias posteriores.

\footnotetext{
${ }^{42}$ Meditaciones Metafísicas.... p. 62.

${ }^{43}$ Como ex sistere, ver nota 14.
} 
Está claro que a memória está localizada no projeto filosófico cartesiano, como mais uma das aptidões humanas submetidas à racionalidade. O racionalismo delega à memória uma função infinitamente mais frágil do que o inatismo platônico original, pois apaga a categoria da recordação ativa e resume a função apenas à lembrança involuntária. Nesse contexto, é evidente que sua natureza fugidia não se alinha à noção de verdade como coisa mensurável, possível de ser selecionada, decomposta, formulada, analisada e remontada, e o crivo da imperfeição, de uma inteligência menor surge como única solução metafísica para explicar a existência da lembrança: as partes imperfeitas do homem que justificam sua necessidade de Deus e sua submissão a Ele.

De fato, como antecipamos no início do capítulo, verificamos que, no método, todos os demais atributos da alma funcionam positivamente apenas quando empenhados em função da racionalidade, e, quando isolados, se voltam para a ilusãodos sentidos. A racionalidade não conduz ao mundo das formas, como em Platão, cuja perspectiva ainda permitia desdobramentos mais complexos nesse trânsito, ela é a manifestação incontestável do Divino no ser humano, e através dela nos definimos enquanto espécie em relação aos demais animais.

A razão, ainda que se alimente das operações inferiores, é potente por si e em si, a ponto do próprio corpo se tornar dispensável e figurativamente "externo" ao ser. O cérebro é o centro do funcionamento, a partir do qual emanam as informações para a extensão, que, por meio dos sentidos, capta novas informações do ambiente externo que deixam impressões no corpo, e através da circulação até o coração são bombeadas novamente para o cérebro. Os erros surgidos na 
formulação do conhecimento quase sempre advém de distúrbios e desvios experimentados em algum estágio de tal processo.

A herança racionalista de Descartes define em muito a neurobiologia como disciplina arborescente na dimensão que a reconhecemos até a atualidade. Apenas muito recentemente em nossa história a medicina cogitou ampliar o conceito de mente para além das atividades do sistema nervoso central, e questionar a perspectiva taxidermista de classificar o corpo em partes superiores e inferiores conforme a noção arbitrária de conhecimento como razão pura, como veremos no capítulo seguinte.

A memória está condicionada a uma espécie de almoxarifado do passado, um conjunto obscuro e indefinido de sensações e idéias de sensações imprimidas na alma pela percepção, e cujo acesso não é possível por um movimento próprio organizado pelo espírito, mas pelo controle da racionalidade e a seu serviço.

Em uma perspectiva diametralmente oposta no que tange aos princípios e processos que orientam as conexões corpo-espírito e suas faculdades, verificamos que pelo empirismo se reafirmará a restrição de âmbito de trabalho da memória (como registro passivo do presente em evocação espontânea) equivalente à que observamos no racionalismo. Tomemos como modelo para análise da memória no associacionismo o tratado de David Hume, reformulado e republicado com o título Investigação acerca do entendimento humano ${ }^{44}$.

\footnotetext{
${ }^{44}$ Em 1739, Hume lança, logo após concluir seus estudos superiores, os dois primeiros livros do Tratado da Natureza Humana: "Of the Understanding" (Do entendimento), e "Of the Passions" (Das Paixões), e no ano seguinte o terceiro, "Of Morals" (Da Moral). A frieza com que público e comunidade científica recebem suas publicações força uma revisão em sua estrutura, de modo que apenas em 1758 o filósofo relançará os dois primeiros tomos transformados sob o título de Investigação acerca do entendimento humano. É pelos conteúdos dessa obra que resgatamos e analisamos o pensamento primário do autor.
} 
Escolhemos esse autor primeiramente porque, acreditamos, seus estudos condensam, radicalizam e potencializam os sentidos que as relações e funções humanas adquirem dentro da tradição empirista. E, principalmente, por que sua obra foi retomada e comentada por Deleuze em um estudo contemporâneo sobre a subjetivação do espírito que proporcionou reflexões e conclusões determinantes para definir a premissa de memória criadora que sustenta a hipótese fundamental de nossa tese.

A leitura primeira da obra de Hume, a partir da qual logo iremos avançar, aponta a experiência como fonte de todo o conhecimento. A experiência é a coleção de impressões que o ser humano adquire ao longo de sua existência e que permite com que ele formule suas idéias orientado por princípios específicos de associação. Tais princípios são a semelhança, a contigüidade e a causalidade, que explicaremos mais detalhadamente a seguir. As idéias, porém, não são produtos da razão pura, mas percepções da natureza semelhante às impressões, entretanto, dotadas de força e vivacidade 45 mais opacas. As idéias, pois, são impressões enfraquecidas. Como são impressões ainda mais frágeis os raciocínios abstratos que se debruçam sobre a geometria, aritmética e demais ramos da matemática, as intuições intelectuais em geral. Somente pela vivência dos sentidos é que as demais operações do entendimento podem ser construídas, e sem a verificação do dado na impressão original nenhum conhecimento é real.

O princípio da semelhança se manifesta quando um objeto ou idéia remete mimeticamente a outra idéia de objeto. Para a contigüidade, objetos e idéias se associam analogamente a outros de forma que seja possível agrupá-los em função

\footnotetext{
${ }^{45}$ Op. Cit., p. 16.
} 
de uma identidade qualquer sem, contudo, definir que sua natureza seja absolutamente idêntica. E, por fim, a causalidade, da qual derivam as relações de causa e efeito entre objetos e idéias, objetos e eventos e idéias e eventos. É da observação mais aprofundada desse último, e mais importante, princípio que se estabelece a síntese primeira do entendimento empírico: o hábito.

Falamos em síntese porque Hume não classifica o hábito como uma categoria de pensamento, e sim como um sentimento que o ser humano apreende mediante a identificação sensível de certa uniformidade no comportamento de objetos e fenômenos. Essa uniformidade não segue preceitos apriorísticos. Quando um mesmo objeto é seguido por um mesmo evento podemos imaginar que existe uma conexão necessária entre eles, uma conexão que está dada na experiência e qualificada por ela. Somente pela combinação das percepções é que podemos levantar todas as variáveis que atuam sobre os fenômenos e definem um ou outro padrão peculiar de conexão (que, conforme Hume, se enquadrará inevitavelmente em um dos três princípios da associação de idéias e, mais comumente, na relação de causa e efeito).

O hábito, por tanto, permite com que identifiquemos padrões relacionais pela percepção de objetos e eventos apresentados imediatamente aos sentidos. De sua aplicação devém a segunda grande operação do entendimento empírico: a capacidade de inferir.

A inferência é a produção de percepções não-imediatas a partir dos dados da percepção imediata sistematizados no hábito. É o poder de extravasar a própria experiência sensível sem abandoná-la, pela projeção das relações entre objetos que não estão naquele instante disponíveis aos sentidos. Não se trata exatamente de 
uma abstração, pois nenhum movimento em direção ao real pode acontecer sem a presença permanente das impressões simples que originam a cadeia de percepções mais complexas.

Não há metafísica, não há transcendência, pois todos os processos dizem respeito às relações naturais de causa e efeito entre os fenômenos/objetos e objeto/idéias, e à capacidade humana de perceber as particularidades das conexões. Inferir é a possibilidade de desdobrar experiências não no nível da representação, mas da observação do possível pela análise de seus graus de probabilidade.

Portanto, a inferência é a reflexão e produção de conhecimento pela prática, espaço em que a experiência ultrapassa definitivamente a repetição para atingir a criação. Ela promove o que Hume chama de crença ${ }^{46}$, o conhecimento pela experiência, que se opõe à certeza, o conhecimento pela intuição. A crença é o sentimento de verdade acerca de um fato adquirido por meio da experiência após todas etapas de superação das probabilidades 47 .

Aqui, a imaginação adquire a função agregadora dos saberes e de suas maquinações. A percepção em si não permite a reflexão sobre a própria percepção, senão sobre seus objetos e sua dinâmica reguladora. É preciso outra faculdade mais “líquida” que permeie os conteúdos da percepção e suas sínteses com as qualidades circunstanciais que definem os sujeitos em si: os afetos e as paixões. E essa faculdade é a imaginação. Notamos certa semelhança com a teoria Aristotélica de onde as imagens da percepção precisam ser transformadas, plasmadas por uma

\footnotetext{
${ }^{46}$ Crença, aqui, adquire sentido oposto à doxa grega, já esclarecida no capítulo anterior.

${ }^{47}$ Hume define, para tanto, duas classes de raciocínios: os raciocínios demonstrativos, que se referem às relações de idéias; e os raciocínios morais, que dizem respeito às questões de fato e de existência. $O p$. Cit p.39.
} 
série de operações mentais até se tornarem imagens aproveitáveis ao intelecto. E a influência direta sobre a fenomenologia moderna, que atribui à fantasia exatamente essa mesma função.

A imaginação representa a grande força criadora do corpo-espírito no empirismo de Hume. Em seu âmbito, as informações da percepção se combinam às particularidades das paixões para re-configurar os sentidos possíveis nas relações de causa e efeitos entre objetos e idéias, idéias e idéias, etc. Se os princípios de associação definem a forma do entendimento, são as paixões e os afetos que qualificam seus conteúdos pelas recombinações imaginativas.

De fato, ao contrário do que uma primeira leitura do tratado pode sugerir, o homem não se define como resultado de uma cadeia correta de raciocínios perceptivos, mas como processo de eterna verificação e re-contaminação das percepções (organizadas em regras sob os três princípios) pela potência fantasiosa da imaginação. Por isso, Hume propõe a co-aplicação sistemática de regras extensivas e regras corretivas quando se busca delimitar o entendimento: a própria natureza da produção do conhecimento pressupõe, contém e é contida pela força anárquica da imaginação.

É curioso que a memória tenha atribuição tão secundária em um projeto filosófico que vê na impressão o seu pilar metodológico, mas é o que sucede. Como podemos ver pelos comentários do autor nas páginas 15 e $16^{48}$ do livro:

\footnotetext{
“Cada um admitirá prontamente que há uma diferença considerável entre as percepções do espírito quando uma pessoa sente a dor do calor excessivo ou o prazer do calor moderado, e quando depois recorda em sua memória ${ }^{49}$ esta sensação, ou a
}

\footnotetext{
${ }^{48}$ Seção II, Da Origem das Idéias.

${ }^{49}$ Grifo meu.
} 
antecipa pela imaginação. Estas faculdades podem copiar ou imitar as percepções dos sentidos, porém nunca podem alcançar integralmente a força e a vivacidade da sensação original. $\mathrm{O}$ máximo que podemos dizer delas, mesmo quando atuam com seu maior vigor, é que representam seu objeto de um modo tão vivo que quase podemos dizer que o vemos ou que o sentimos. Mas, a menos que o espírito esteja perturbado pela doença ou loucura, nunca chegam a tal grau de vivacidade que não seja possível discernir as percepções dos objetos. Todas as cores da poesia, apesar de esplêndidas, nunca podem pintar os objetos naturais de tal modo que tome a descrição pela paisagem real. $\mathbf{O}$ pensamento mais vivo é sempre inferior à sensação mais embaçada." ${ }^{50}$

A memória novamente está como o borrão do vivido. Ela não participa do movimento criador da imaginação, que pela sucessão de associações pode operar mesmo sem esta. Se a força do registro está no centro do pensamento empirista, a memória não aparece como o provável agente principal de cooperação da percepção, para evocar as impressões não-imediatas e produzir as idéias e as percepções complexas, a que Hume denomina impressões de reflexão51. As imagens mnemônicas subsistem como uma espécie de fantasma do objeto no espírito, compreendidas apenas em suas propriedades retentivas e, ainda assim, desfiguradas como impressões pálidas e incompetentes.

Entretanto, há de se ter um pouco de persistência para ir além do discurso extensivo do autor e entrever em suas considerações "subjacentes" uma possível perspectiva mais positiva para a atividade mnemônica na dinâmica das sínteses perceptivas. Essa brecha pode ser encontrada em suas observações sobre o movimento das impressões passadas e presentes para organização do hábito.

\footnotetext{
${ }^{50}$ Grifo meu.

${ }^{51}$ As impressões de reflexão qualificam o espírito, são os efeitos da ação dos princípios gerando associações com significados específicos e, portanto, atos cognoscíveis de teor específico que definem o espírito pelas suas particularidades. Assim, se as impressões de sensação dão origem ao espírito, são as impressões de reflexão, o movimento de sujeição das sensações aos princípios de associação, à imaginação criadora e sua correção que o singularizam.
} 
Em algumas passagens importantes de sua Investigação, Hume situa a memória como olugar para onde a percepção deve se deslocar a fim de esclarecer e confrontar os dados presentes com as impressões antigas. A memória tem seu status, por assim dizer, melhor considerado, e surge como o acervo de dados passados, que permite a presença das impressões, das idéias e dos raciocínios sobre estas no espírito para além da aparição aos sentidos. Em última instância, é a memória que torna a inferência possível pela preservação dos materiais que se multiplicam como referências de aprendizado na percepção. Como podemos observar no trecho que se segue:

\begin{abstract}
"Pela história, conhecemos os eventos de épocas passadas; todavia, devemos prosseguir consultando os livros que contém esses ensinamentos e, a partir daí, remontar nossas inferências de um testemunho a outro até chegar às testemunhas oculares e aos espectadores desses eventos remotos. Numa palavra, se não partirmos de um fato presente à memória ou aos sentidos, nossos raciocínios serão puramente hipotéticos; e seja qual for o modo como estes elos particulares estejam ligados entre si, toda a cadeia de inferência não teria nada que lhe servisse de apoio e jamais por meio dela poderíamos chegar ao conhecimento de uma existência real."
\end{abstract}

Eis a memória situada pelo autor em uma posição que nos parece mais coerente à lógica de colaboração entre as faculdades própria de sua teoria do conhecimento. O homem não se dá apenas pela percepção, é o que Hume acaba de nos dizer. A experiência pode ser a fonte de todo conhecimento, mas ela não esgota o processo nas sínteses presentes. O espírito ultrapassa o vivido: infere e inventa o que está além dela, e por esse processo se faz sujeito.

Encontramos no primeiro livro de Gilles Deleuze Empirismo e Subjetividade Ensaio sobre a Natureza Humana Segundo Hume uma releitura do Tratado que

\footnotetext{
52 Op.Cit., p. 47.
} 
parte dessa observação final para sustentar a hipótese do ultrapassamento do dado como movimento de subjetivação que iluminou profundamente nossa noção de memória criadora. Recuemos um pouco para uma questão empírica necessariamente anterior: como o sujeito se constitui no dado? $\mathrm{E}$, conscientes de que não há relação exterior à experiência: como na experiência se constitui um sujeito capaz de ultrapassá-la?

Primeiramente, esclareçamos o que Deleuze considera como dado:

“[...] o fluxo do sensível, uma coleção de impressões de imagens, um conjunto de percepções. É o conjunto do que aparece, o ser igual á aparência, é o movimento, a mudança sem identidade nem lei. Falar-se-á de imaginação, de espírito, designando assim não uma faculdade, não um princípio de organização, mas um tal conjunto, uma tal coleção. O empirismo parte dessa experiência de uma coleção, de uma sucessão movimentada de percepções distintas. Ele parte dela, na medida em que são distintas, na mediada em que são independentes. Com efeito, seu princípio, isto é, o princípio constitutivo que dá um estatuto à experiência, não é de modo algum aquele segundo o qual 'toda idéia deriva de uma impressão', cujo sentido é apenas regulador, mas é, isto sim, aquele segundo o qual 'tudo o que é separável é discernível e tudo o que é discernível é diferente'." "53

A experiência é o movimento de idéias reconhecidamente separadas, e que, em suas existências diferenciadas, carregam o potencial de associação que define cada percepção. Ou ainda: “toda percepção é uma substância, e cada parte distinta de uma percepção é uma substância distinta. ${ }^{54}$ ". Logo, é antinômico imaginar que o dado possa em si aparecer aos sentidos e ultrapassar a si próprio, ou contenha a priori os direcionamentos que condicionariam essa ultrapassagem.

Já vimos anteriormente que é na sistematização e combinação criativa da coleção de impressões que a imaginação diferencia sua função A imaginação

\footnotetext{
${ }^{53}$ Op. Cit. p. 95.Impossível não reconhecer nessa passagem a fundamentação imediata que Deleuze identifica no empirismo para sustentar o princípio de diferenciação como o concebe em sua própria teoria.

${ }^{54}$ Hume apud Deleuze. Op. Cit. p. 96.
} 
combina os "princípios da associação" (semelhança, contigüidade e causalidade) aos "princípios da paix ão" (a afetividade como individuação) para particularizar o processo de constituição do sujeito no espírito ${ }^{55}$. Em outras palavras:

\begin{abstract}
"A associação de idéias não explica que seja, sobretudo, esta a (idéia) a ser evocada e não aquela. Desse ponto de vista, deve-se também definir a relação como 'essa circunstância particular pela qual julgamos bom comparar duas idéias mesmo quando essas se acham unidas arbitrariamente na imaginação [...] O que dá à relação sua razão suficiente é a circunstância. [...] Quando Freud e Bergson mostram que a associaç ão de idéias explica apenas o superficial em nós, o formalismo da consciência, eles querem dizer, essencialmente, que somente a afetividade pode justificar o conteúdo singular, o profundo, o particular [...] Tudo se passa como se os princípios de associação dessem ao sujeito sua forma necessária, ao passo que os princípios da paixão dão-lhe seu conteúdo singular."56
\end{abstract}

Esses são os movimentos da subjetivação do espírito prático/empírico, que primeiro se apóia no esquematismo das regras propostas pelos princípios da associação para logo ultrapassá lo pelas sínteses da inferência e da imaginação, que por sua vez não funciona completamente livre, senão orientada pelos princípios da associação. Todo processo, permeado pelas circunstâncias da afetividade. Sua finalidade intencional se dá pela dualidade entre os termos e as relações, de que se conclui: "como o sujeito se constitui no dado? Sendo o dado o produto dos poderes da Natureza, sendo o sujeito o produto dos princípios da natureza humana ${ }^{7 \text { ", }}$ e no reconhecimento de que não há regras apriorísticas que expliquem as especificidades da cada conexão.

\footnotetext{
${ }^{55}$ Os princípios da associação, que são responsáveis pela produção das impressões reflexivas e que promovem o entendimento, e os princípios da paixão, que são o domínio da afetividade, compõem os princípios da natureza humana.

${ }_{56}$ Op.Cit. pp. 116-117.

${ }^{57}$ Op. Cit. p. 122.
} 
Portanto, está claro que o sujeito é a irrupção de um processo no espírito nos termos que já foram descritos, em que a imaginação organiza criativamente os conteúdos informativos e afetivos. Notemos a passagem:

\begin{abstract}
"Com efeito, o empirismo é uma filosofia da imaginação, não uma filosofia dos sentidos. Sabemos que a questão: como o sujeito se constitui no dado? Significa: como a imaginação devém uma faculdade? Segundo Hume, a imaginação devém uma faculdade quando, sob o efeito de princípios, se constitui uma lei de reprodução de representações, uma síntese da reprodução. ."58
\end{abstract}

E mais adiante: “a memória, os sentidos e o entendimento estão todos fundados sobre a imaginação.59". Observamos que, ao passo que se profunda e se esclarece o pensamento deleuziano sobre as questões empiristas, torna-se incoerente insistir no caráter passivo da memória diante do poder da percepção e da imaginação e da atividade-hábito. Vimos que sem a memória, a inferência só consegue se voltar para as impressões "muito vivas" que, não sendo estas experimentadas no instante presente, não podem ser outras que não aquelas “avivadas” pela memória, seja ela mais recente ou mais antiga60. Se o local das impressões é o corpo, o seu espaço sutil de agregação é exatamente a memória, a capacidade de preservar as impressões de um corpo que não cessa de ser impresso jamais, e cujas demais operações não sucedem linearmente, mas simultaneamente a esse fluxo.

Se o corpo e suas impressões movem-se permanentemente no tempo e espaço, então não é possível falar de impressão sem ligar intimamente o conceito à memória, a menos que se pressuponha uma capacidade de percepção atemporal ou

\footnotetext{
${ }^{58}$ Op. Cit., p. 124.

${ }^{59}$ Op.Cit., p. 143.

${ }^{60}$ Sabemos que, muitas vezes, os conteúdos mais remotos podem ser mais claros sensorialmente para o indivíduo do que os registros recentes, como geralmente ocorre nos casos de senilidade.
} 
que se atribua à percepção ou a qualquer outra faculdade o poder de evocar impressões passadas, o que não é o caso. A impressão mais viva ou a mais fraca já não pertencem mais ao presente utópico, já são registro, já são história no corpo.

Em um trecho muito esclarecedor, Deleuze fala de uma nova concepção de tempo promovida pelo hábito. Vejamos:

“Considerado no modo de aparição de suas percepções, o espírito era essencialmente sucessão, tempo. Agora, falar de um sujeito é falar de uma duração, de um costume, de um hábito, de uma expectativa [...] O hábito é a raiz constitutiva do sujeito, e em sua raiz, o sujeito é a síntese do tempo, a síntese do presente e do passado em vista do porvir."61

O tempo imaginado pelo hábito não é mais uma sucessão aleatória de eventos, é um movimento refletido, "refletível", no qual o futuro pode ser projetado pelos conteúdos da experiência. É tremendamente forços o isolar a memória da formação do hábito, como na passagem seguinte:

${ }^{61}$ Op.Cit., p. 103.

${ }^{62}$ Op. Cit., p. 105.

"o tempo era estrutura do espírito; agora, o sujeito se apresenta como síntese do tempo. E para compreender o sentido dessa transformação, é preciso assinalar que, por si mesmo, o espírito comportava a memória no sentido que Hume dá a essa palavra: distinguiam-se na coleção das percepções, segundo os graus de vivacidade, as impressões dos sentidos, as idéias da memória e as idéias da imaginação, A memória era a reaparição da impressão sob forma de uma idéia ainda viva. Mas, justamente por si mesma, ela não qerava síntese alguma no tempo; ela não ultrapassava a estrutura ela encontrava seu papel essencial na reprodução das diferentes estruturas do dado. É o hábito, ao contrário, que vai apresentar-se como uma síntese, e o hábito remete ao sujeito. A lembrança era um antigo presente, não um passado. Devemos chamar passado não simplesmente aquilo que foi, mas aquilo que determina, que atua, que compele, que pesa de uma certa maneira. Nesse sentido, o hábito é para a memória o que o sujeito é para o espírito, mas, além disso, e mais ainda, ele prescinde facilmente dessa dimensão do espírito que se chama memória; o hábito não tem necessidade de memória."62 
A sentença que encerra o parágrafo acima, nos parece, surpreendentemente, contradiz o pensamento desenvolvido até então, e soa não apenas forçosa, mas sofismática, em um sentido que só se explica pela insistência em se preservar a essência do empirismo pela manutenção de uma hierarquia de faculdades já irremediavelmente abalada pela própria evolução de pensamento do autor. Falar em impressão "mais ou menos viva" nada mais é do que de falar da memória em termos fugidios, e aí está a questão-chave pra re-posicionar o memória de forma mais coerente na teoria.

Atribuiu-se à impressão uma atividade que extravasa o seu âmbito. Como explicamos anteriormente, se pudéssemos isolar o instante presente da experiência, não seria pela memória que as sensações se imprimiriam nos sentidos, mas pela própria vivência dos sentidos naquele específico recorte temporalespacial. Porém, tal fenômeno não é efetivamente possível, e a impressão de agora já é memória de impressão. Reconhecendo isso, conclui-se que a maior parte de nossa "coleção de impressões" está fixada pela memória, e a formação do hábito realmente não nos parece possível sem a recuperação de experiências passadas (e não de um "antigo presente", como afirma Deleuze, sugerindo uma antinomia ilusória de valor entre fatos mais ou menos marcantes).

Reorganizadas as atribuições, acreditamos que a memória está no centro tanto da formação do hábito como nas sínteses criativas da imaginação. No hábito, por todos os argumentos que já apresentamos, mas que também justificam sua participação na imaginação Não é possível se criar novos sentidos sem que existam registros de objetos e relações sobre os quais refletir. Se compreendermos a memória como o âmbito das impressões no corpo mediante ação do tempo, então 
ela alimenta todos os demais movimentos, supera a evocação, desdobra se em devir percepção, devir imaginação, devir criação.

De fato, ao arriscar que o empirismo de Hume é uma filosofia da imaginação, e não dos sentidos, Deleuze assume uma abordagem transformadora sobre os limites entre o que definimos tradicionalmente como "faculdades" humanas, e que nos parece mais adequado para compreendermos o corpo expressivo em seu funcionamento multidisciplinar. Ele extrapola o empirismo original para apontar um modelo de sujeito que se não se constitui mais como essência metafísica que mora em um corpo que percebe.

Essa cisão entre corpo e alma originou todas as diversas polaridades na distribuição dos âmbitos de atuação dos processos que participam da criação humana na história da filosofia, e que propõem a existência de nichos físicos ou metafísicos fictícios para o que chamamos "sujeito". Em determinada tradição a razão pertence ao domínio do espírito, enquanto a percepção e a memória estão ligadas somente à extensão. O indivíduo se dá por uma racionalidade intuitiva e abstrata espiritual-cerebral autônoma aos processos corporais. Em outra, as impressões e a percepção produzem o entendimento pela vivência dos sentidos. O sujeito se forma pelas operações do corpo em progressões de complexidade a partir de um mesmo processo multiplicado pela imaginação. O espírito está em algum lugar mal resolvido, já que, aqui, a metafísica foi exterminada pela lógica operacional da associação.

Deleuze retoma o caminho anti-transcendentalista de Hume para desenvolver uma noção de sujeito como processo físico (não apenas fisiológico) de ultrapassamento de seus próprios extratos de saber, em que o conhecimento é 
problematizado para muito além do embate inatismo/empirismo. O sujeito se define não mais como essência/conteúdo em formação (seja este inato ou adquirido) que está aqui ou ali, mais ligado a esta ou àquela faculdade; mas como movimento, devir, fluxo de vivência, retenção e ultrapassamento do retido na simultânea multiplicidade de operações das quais participa e às quais organiza e atualiza para se construir. Em última instância, pois, a ultrapassagem não se refere somente ao dado, mas aos limites das faculdades tomadas em uma perspectiva arborescente. Nesses termos, encontramos a definição de sujeito que nos é útil e aplicável ao estudo da criação artística. 
Capítulo III - Aspectos da Neurobiologia contemporânea: tipos de memórias, o mapeamento cerebral como instrumento de análise da construção, evocação, preservação e destruição das memórias.

A partir da segunda metade do século passado, é possível afirmar, sem receio, que a neurobiologia realizou sua revolução copernicana particular com a criação de tecnologias inéditas de mapeamento cerebral. Evidentemente, esse "levante" está relacionado à descoberta da dupla hélice do ácido desoxirribonucléico (o DNA) em 1953, que produziu a medicina quântica e introduziu a perspectiva geneticista a todas as demais áreas das ciências médicas e comportamentais. Cresciam, então, outras duas disciplinas igualmente fundamentais para o estudo da memória: a bioquímica e a biologia molecular, mas sua utilização em pesquisas sobre as funções do sistema nervoso só aconteceria mais de uma década mais tarde.

Com o desenvolvimento dos novos aparelhos e técnicas de visualização da atividade cortical e subcortical, os clássicos experimentos baseados na observação externa dos comportamentos e nas medições por eletrodos ou termo-ativação puderam ser substituídos (ou, melhor dizendo, combinados) a procedimentos infinitamente mais precisos, através dos quais se tornou possível delimitar mais claramente a intensidade das sinapses para cada região conforme o tipo de atividade cerebral em exercício.

Esse mapeamento iluminou profundamente o estudo da formação das memórias e das cadeias associativas envolvidas nas suas sínteses. De fato, foi a partir desse período que uma série de preceitos da medicina anterior puderam ser derrubados (como a imobilidade dos neurônios) ou confirmados. 
Lembremos, antes, do pioneiro da atividade: Ivan Pavlov63 (1849-1936), o fundador da moderna biologia da memória. Pavlov foi o primeiro a perceber que a aquisição da memória não é um processo monolítico, tanto em termos de experiência sensível quanto de registro neurológico. Ele foi um dos primeiros cientistas modernos a sugerir que a memória não funciona como faculdade estrita e una, mas pensou em "memórias” como construções sinápticas que acontecem em regiões diferentes do córtex conforme a permanência e intensidade de cada registro.

Lamentavelmente, Pavlov não tinha, em seu tempo, o aparato tecnológico necessário para aprofundar suas intuições, que provavelmente alavancaria suas pesquisas do restrito domínio dos reflexos e condicionamentos para um entendimento mais amplo das funções que envolvem a formação desses reflexos. Acreditava, como a maioria dos psicólogos experimentais da época, que os comportamentos poderiam ser explicados por simples seqüências de reflexos, portanto, em sua doutrina, não havia a necessidade de postular algo que permitisse a fixação das modificações destes em circuitos neuronais através de processos moleculares. Talvez isso explique porque, em sua vasta obra, Pavlov faça tão poucas referências diretas à memória enquanto função específica64 .

O mapeamento cerebral parte de uma série de procedimentos que utilizam principalmente a eletro definição para configurar quais seções do cérebro entram em atividade mais intensa em determinada situação hormonal e/ou neuro-

\footnotetext{
${ }^{63}$ Com Vladimir Brekhterev, Pavolv foi o maior pesquisador da reflexologia na Rússia do século XX. Seu trabalho sofreu intensas críticas desde o surgimento da psicanálise moderna, mas é inegável a contribuição de seus estudos sobre condicionamento, associação e categorias de reflexo para a neurologia atual.

${ }^{64}$ Pavlov também fez uma descoberta imprescindível para o entendimento da memória em relação aos demais estados de ânimo: a de que o ser humano grava melhor e tem menos tendência a esquecer a memórias de alto conteúdo emocional, às quais ele chamava de "biologicamente significativas".
} 
humoral. A abordagem ganhou força a partir dos anos 60 e 70, com o aprimoramento das máquinas de tomografia computadorizada e eletroencefalograma, e a possibilidade de visualização por termo-coloração da intensidade de trabalho em cada setor do cérebro. Tais máquinas foram projetadas como parte de toda uma corrida da engenharia neuro-cibernética mundial no sentido de aprimorar a microscopia para desvendar os mistérios das ciências biomoleculares, cujo objetivo maior seria a decodificação total do genoma humano. Por isso, em alguns momentos de nossa tese, faremos referência a cientistas de diferentes países sobre a autoria de uma ou outra descoberta, pois suas investigações correram simultaneamente e pode ser arriscado atribuir a paternidade exclusiva de uma descoberta a apenas um pesquisador em particular.

Dentre os novos experimentos referidos, devemos destacar, pelo menos, dois processos eletrofisiológicos descobertos e descritos já na década de 1970 pelos pesquisadores Timothy Bliss e Graham Collingridge (de Londres), Uwe Frey e Klaus Reymann (da Escola de Matthies), Aryeh Routtenberg (de Chicago) e Eric Kandel (de Nova York): a potenciação de longa duração e a depressão de longa duração ${ }^{65}$. Por meio desses processos, foi possível, pela primeira vez, medir e documentar a organização bioquímico-fisiológica do cérebro em atividade de fixação de registros não por alguns minutos apenas, mas por horas, semana e até meses. Assim, toda noção de amplitude da capacidade mnemônica cerebral teve de

\footnotetext{
${ }^{65}$ A potenciação consiste no persistente aumento das respostas dos neurônios à estimulação breve e repetitiva de um axônio ou grupo de axônios que fazem sinapses com elas. A depressão é a inibição perene de uma determinada resposta sináptica em conseqüência da repetida estimulação de uma via aferente (que leva alguma informação ao cérebro). Toda uma série de comportamentos antecipada por Pavlov encontram aqui a sustentação neuroquímica que lhes faltava.
} 
ser revista, e teve início uma nova classificação das "memórias" conforme sua duração e região de processamento. Vamos descrevê las.

A memória de trabalho é um mecanismo extremamente fugaz de fixação, dura apenas alguns segundos, no máximo minutos, e não produz arquivos. Ela serve para "dar um panorama" das informações, combinando-as com extrema velocidade e fornecendo os dados iniciais que contextualizam a situação e definem se vale à pena ou não sintetizar uma nova memória sobre o material aferido. Também é chamada de memória imediata, e depende fundamentalmente da atividade elétrica do córtex pré frontal (localizado na frente da área motora) ${ }^{6} 6$ eda porção mais anterior do lobo frontal, necessitando de poucas alterações bioquímicas para ser ativada. A perda de informações da memória de trabalho é considerável, e é perfeitamente natural que seja assim, uma vez que a natureza de sua atividade consiste em realizar um levantamento exaustivo e imediato de combinações de dados para serem eliminados conforme as necessidades do indivíduo diante da situação. Por tanto, essas perdas não podem ser consideradas como um esquecimento real, já que estão programadas e previstas na hierarquia de funções do sistema nervoso central.

Essa memória, ainda que pareça "rasa", é muito importante para a saúde mental, pois funciona como uma "gerenciadora da realidade", coordenando a atuação das demais memórias subjacentes. Através dela, a informação permanece "viva" até ser incorporada pelos outros sistemas mnemônicos (através do córtex entorrinal) ou descartada pela mente. Também vem da memória de trabalho a

\footnotetext{
${ }^{66}$ Em casos de lesões em neurônios pré-frontais, a memória de trabalho também cessa. Por isso, é comum pacientes com lesões acidentais nessa região passarem a desenvolver comportamentos paranóicos, ou crises esquizofrênicas.
} 
capacidade do cérebro em identificar rapidamente situações de risco, e reagir a elas com eficiência. A memória de trabalho, no entanto, não deixa traços neuroquímicos ou comportamentais.

As memórias que produzem arquivos, ou seja, aquelas que registram fatos, eventos ou conhecimentos são chamadas memórias declarativas (por que nós podemos declarar que existem e relatar como as adquirimos). Entre elas, aquelas que se referem a eventos aos quais assistimos, ou dos quais participamos recebem o nome de episódicas (ou autobiográficas); e aquelas que envolvem conhecimentos gerais são denominadas semânticas.

Existem, ainda, as memórias procedurais (ou memórias de procedimentos), que estão envolvidas com as habilidades ou capacidades motoras de cada indivíduo, e com o que costumamos chamar de "hábitos". É forçoso classificá la como declarativas, uma vez que não sabemos exatamente descrever todo processo que envolve a execução física de um trabalho, como andar de bicicleta, por exemplo. Mas não há complicação no instante de execução da tarefa: a seqüência de mecanismos necessários é prontamente resgatada e acionada.

Alguns autores modernos ${ }^{67}$ dividem as memórias entre explícitas e implícitas. As memórias que adquirimos sem perceber são tidas como implícitas, e aquelas adquiridas com plena intervenção da consciência, são explícitas. A memória procedural, geralmente, é implícita, enquanto a semântica quase sempre é explícita. Essa classificação, no entanto, não é totalmente aceita, dado a flutuação entre os campos que caracteriza os processos de aprendizado em geral. É mais

\footnotetext{
${ }^{67}$ J. M. Danion, T. Meu lemans, F. Kauffmann-Müller, H. Vermaat. Intact implicit learning in schizophrenia. American Journal of Psychiatry, 158, pp 944-948, 2001.
} 
comum acreditar que as informações se processam geralmente na tensão entre tais limites.

Tanto as memórias episódicas como as semânticas necessitam de uma boa memória de trabalho para se construírem, e, por tanto, de um bom funcionamento do córtex pré-frontal. As principais estruturas nervosas que participam de seu funcionamento são duas áreas intercomunicadas do lobo temporal: o hipocampo e o córtex entorrinal. Essas regiões trabalham associadas entre si, e em comunicação com outras áreas do córtex, como o córtex cingulado e o córtex parietal.

A modulação das memórias declarativas, porém, acontece principalmente em outra região, situada na área basolateral do núcleo amigdalino (ou amígdala) e nas grandes regiões controladoras dos estados de ânimo (os grandes responsáveis pela saúde das memórias): a substância negra, o lócus cereulus, os núcleos de Rafe e o núcleo basal de Meynert. Os axônios dessas últimas duas regiões atingem o hipocampo, a amígdala, e os córtices entorrinal, cingulado e parietal, e são responsáveis pela liberação dos neurotransmissores dopamina, noradrenalina, serotonina e acetilcolina. Assim, podemos perceber que as memórias declarativas estão mais sujeitas aos estados neuro-humorais.

Existe um tipo de memória que não se encaixa exatamente em nenhuma das categorias anteriores, que é a capacidade de evocar informações por meio de “dicas”, fragmentos de imagens, palavras, gestos ou sensações. É conhecida como priming, expressão para a qual não existe uma tradução apropriada em português. A existência do priming comprova que muitas memórias declarativas ou procedurais são adquiridas originalmente de duas maneiras paralelas: uma envolvendo um conjunto relativamente grande de estímulos, e outro utilizando 
apenas "pedaços" desses conjuntos. É um tipo de memória que se processa essencialmente na região neocortical, além do córtex préfrontal e das áreas associativas. É comprovado que pacientes com lesões corticais profundas apresentam deficiência desse tipo de memória, e necessitam de mais fragmentos do que o normal para evocar uma informação.

As memórias também podem ser classificadas pelo tempo que duram. As memórias declarativas de longa duração levam muito tempo para serem consolidadas. Nas primeiras horas após sua aquisição, estão suscetíveis à interferência de inúmeros fatores: traumatismos, drogas ou mesmo outras memórias. A exposição a um ambiente novo dentro da primeira hora de aquisição, por exemplo, pode deturpar seriamente ou até cancelar a formação definitiva de uma memória de longa duração, o mesmo ocorrendo mediante uma batida ou um choque.

Convencionou-se chamar de memória de curta duração à memória que dura poucas horas, exatamente o tempo necessário para que a memória de longa duração comece a se consolidar. Por quase um século, se discutiu se a memória de curta duração era mesmo uma categoria mnemônica própria ou uma fase inicial da memória de longa duração. Atualmente, já se sabe que a primeira hipótese é a correta, pois ainda que a memória de curta duração utilize as mesmas estruturas nervosas que a de longa duração, seus mecanismos neuroquímicos são distintos e particulares. Outra característica peculiar é que a memória de curta duração, ao contrário da de longa, é bastante resistente aos agentes que afetam a consolidação das informações. 
Por fim, há as memórias que duram muitos meses ou anos, conhecidas por memórias remotas. Tais memórias são geralmente resistentes por estarem associadas a emoções intensas ("biologicamente significativas", como Pavlov preferia). Isso explica porque é tão comum idosos lembrarem mais claramente de eventos da juventude do que do passado recente.

Podemos, portanto, concluir que as áreas responsáveis pela construção e evocação da maior parte das memórias são o hipocampo e o córtex circundante do lobo temporal. O hipocampo é uma área filogeneticamente antiga do córtex temporal e que tem várias funções. A principal é produzir e evocar memórias, ou induzir o resto do córtex cerebral a fazer o mesmo (partindo das regiões vizinhas a ele). A região imediatamente mais próxima, e, portanto, de importância crescente na formação das memórias, é o córtex localizado abaixo do hipocampo no lobo temporal, denominado de entorrineal. Ele se interliga por meio de um considerável volume de fibras nervosas tanto às demais regiões do córtex cerebral como ao núcleo amigdalino, também localizado no lobo temporal, e gerenciador das substâncias que desencadeiam e controlam as emoções. Dessa forma, o córtex entorrineal possui conexões de ida e volta com o resto do córtex, o hipocampo e o núcleo amigdalino, e promove o fluxo necessário entre imagens sensoriais novas, armazenadas e entre estados de ânimo específico para a construção de cada registro.

Os mecanismos bioquímicos envolvidos nas sínteses realizadas por essas estruturas para formação e evocação da memória são bastante individualizados e já estão devidamente rastreados. Na formação das memórias pelo hipocampo, participam a expressão gênica, a síntese protéica e várias vias metabólicas 
vinculadas. Conforme o tipo de memória, tais processos bioquímicos são necessários também na amígdala basolateral e em várias outras localizações do córtex cerebral. Na expressão das memórias (lembrança, evocação) atuam algumas dessas vias bioquímicas, mas não há ativação gênica nem síntese protéica. Da mesma forma, a memória de curta duração não requer síntese protéica nem expressão gênica, mas utiliza diversas vias metabólicas geralmente distintas daquelas utilizadas pela memória de longa duração. Sua formação acontece em alguns segundos ou minutos a partir das informações da memória de trabalho, e sua atividade molecular é bem mais simples do que aquela envolvida no processamento de memória de longa duração. Ela funciona, quase exclusivamente, nasáreas restritas ao hipocampo e ao córtex entorrineal.

A aquisição das memórias é um fenômeno que envolve tantas variáveis que justifica a impossibilidade de uma experiência ser igual para dois indivíduos. Em primeiro lugar, temos a peculiaridades do aparato sensorial de cada um. Cada corpo é único, e daí advém sua zona de contato com o mundo e a intensidade e natureza das informações aferidas e eferidas pelo seu organismo. Cada experiência e "lida" pelo sistema nervoso periférico e conduzida ao sistema nervoso central para ser traduzida em um hiper-complexo código de substâncias químicas, responsáveis pela produção dos registros e pela forma como os classificamos.

Nesses processos, muitas das memórias são adquiridas por meio da associação de um estímulo com outro estímulo, ou de um estímulo com uma resposta. Novamente voltamos a Pavlov, que, já no século passado, observou que a resposta mais comum dos animais a um estímulo ou a um conjunto de estímulos novos (não dolorosos) era uma reação de orientação, que ele chamou reação de "o 
que é isso?”. A repetição do estímulo leva á supressão gradual da reação de orientação, ao que chamamos habituação. Essa é a forma mais simples de aprendizado e de construção da memória, que surge a medida em que a reação imediata pode ser suprimida dada a identificação do estímulo.

Pavlov estabeleceu, ainda, que nos aprendizados associativos, se um estímulo novo é equiparado a outro de significado biológico semelhante (dor, prazer, etc.), a resposta ao primeiro pode mudar, e ficar condicionada ao segundo. Assim, os estímulos neutros cuja resposta muda por sua associação com outros passam a ser chamados estímulos condicionados, e a resposta nova a esse estímulo, resposta condicionada. Aqueles estímulos que permanecem "fiéis" a suas respostas são chamados estímulos incondicionados, e suas repostas, por conseguinte, respostas incondicionadas.

Toda ligação entre um estímulo e uma resposta é denominada de reflexo. Pavlov foi o grande teórico da aprendizagem associativa do século passado, quando documentou esse modus operandi cerebral através de incontáveis experiências com várias espécies animais além das cobaias tradicionais. A apresentação de uma resposta condicionada a um estímulo neutro, que a princípio não a produzia, chama-se reflexo condicionado. Podemos afirmar, portanto, que todo aprendizado associativo se baseia na construção de reflexos condicionados, de uma forma ou de outra.

E, certamente, tão importante quanto a faculdade do registro é a faculdade do esquecimento. O esquecimento é um fenômeno que desempenha papel adaptativo na estruturação a mente. Não há dúvida de que esquecemos a grande maioria do material experimentado. Ele é o mecanismo que nos permite selecionar 
as informações que devem realmente participar do processo de consolidação, e em que nível. Mas ele também pode se apresentar como conseqüência de um trauma de qualquer natureza, e ser uma reação da psiquê humana a um impacto maior do que sua estrutura afetiva pode suportar. De toda forma, é uma das mais eficientes defesas do cérebro contra a sobrecarga, tanto no que se refere à quantidade de informação, quanto à sua qualidade. Essa forma de esquecimento, provocada por traumas psicológicos, também é denominada repressão.

Essas são, basicamente, as categorias adotadas para tratar da memória na neurociência contemporânea. Os mecanismos que explicam sua formação estão cada vez mais claros para a Medicina, e a contribuição de tais descobertas para todas as áreas do aprendizado são incalculáveis. Por meio da potenciação e da depressão de longa duração, por exemplo, já é possível, há mais de uma década, monitorar não só as áreas, mas uma grande quantidade dos receptores, neurotransmissores e neuromoduladores envolvidos na consolidação da memória de longa duração. E seria impossível não destacar a revolução que representou para o diagnóstico de imagem a Ressonância Magnética Nuclear, técnica que permite medir a ativação metabólica de uma ou outra região do cérebro quando o indivíduo está formando ou recordando memórias de um ou outro tipo, relativas a uma situação em que não mais se encontra.

Essas técnicas, contudo, ainda não são capazes de identificar quais passos metabólicos são modificados, nem detalhar o funcionamento das áreas que participam de diversas atividades mentais, como o córtex préfrontal, por exemplo. E eis um dos grandes problemas de sua aplicação imediata ao aprendizado das 
Artes: não permitem definir o tipo de reação que o indivíduo irá manifestar mediante determinado estímulo.

Antes de entrarmos especificamente na questão das Artes, há ainda que se ressaltar as restrições na utilização do mapeamento cerebral como técnica de aplicação direta no estudo da linguagem, que interessa a nossa área de investigação. Uma pesquisa exemplar conduzida pela Profa. Lêda Tomich nos Estados Unidos utilizou uma ferramenta de ponta, a Ressonância Magnética Funcional, para medir a intensidade e a localização da atividade cerebral durante a execução da tarefa de identificar os pontos principais na leitura de um texto. Ela utilizou oito alunos de graduação da Universidade de Carnegie Mellon, e usou como estímulo experimental doze parágrafos de textos da língua inglesa, língua nativa dos alunos.

Para realizar sua pesquisa, a professora fez um levantamento das publicações já existentes sobre o tema, e o resultado foi um número razoável de estudos sobre a leitura de uma palavra, pouquíssimo estudos sobre a leitura de uma oração completa e quase nenhum sobre a compreensão de textos. E mesmo o resultado de sua pesquisa apontou dados que dizem muito mais respeito às neuropatologias dos alunos do que ao ensino da leitura ou da fala.

Encontramos, portanto, dois problemas cruciais que limitam a aplicação direta das novas descobertas da neurociência da mente ao ensino. O primeiro diz respeitoà pouca utilização dessas técnicas para fins que não sejam de diagnóstico e tratamento de doenças ou lesões. Portanto, a ponte que une as descobertas realizadas até hoje na área às práticas da cena é longa, e abre espaço para todo o tipo de especulação conforme a hipótese a ser defendida. O segundo, e talvez mais 
complexo, consiste na incapacidade de se prever que tipo de reação o indivíduo apresentará diante de cada categoria de estímulo cerebral.

Saber a área do cérebro que está em atividade em cada situação permite definir uma tendência de comportamento, mas não as ações que serão praticadas nesse estado. Uma pessoa com baixa dosagem de serotonina pode tanto chorar desesperadamente por horas quanto pegar uma arma e matar alguém. E, nas artes performáticas, como sabemos, interessa a ação física da cena.

Seria possível até mesmo uma experiência de monitoramento com eletrodos de um performer em seu processo de criação. Com a tecnologia atual, seria perfeitamente viável. Poderia- se documentar cada etapa de trabalho e definir quais áreas estariam envolvidas em cada instante. Mas qual seria a contrapartida pedagógica de tais descobertas? Primeiramente, esse mapa seria restrito exclusivamente ao processo daquele performer naquele trabalho específico, não constituindo material de estudo reaproveitável para mais ninguém. E, de toda forma, saber quais áreas do cérebro participam de um estágio de criação não é de grande valia nem mesmo para o performer reproduzir os passos, uma vez que essa informação sozinha não permite alavancar os estados internos desejados. Em outras palavras: conhecer o mapa cerebral de cada imagem não ajuda a resgatá-la, nem mesmo a produzir novas informações emocionais ou sensoriais.

O exercício da memória para a criação do performer é infinitamente mais complexo do que o mapeamento cerebral puro pode conceber. Não estamos tratando de diagnosticar doenças ou falhas que ocupam lugares específicos da mente. Estamos trabalhando com linguagens que nem mesmo podem ser 
classificadas ou compreendidas pela lingüística strictu sensu, para as quais não há certo ou errado.

Para estimular determinado estado psíquico, não basta saber em qual área do cérebro ele se desenvolve. O aprendizado das experiências é um fenômeno vivo, que interfere permanentemente na construção das memórias, seja para evocar ou para apagar informações. Não há neuroquímica que produza um resultado se o indivíduo não tem um repertório diversificado de experiências emocionais e uma capacidade criativa que lhe permita simular as experiências que não provou. É de uma psiquê rica em informações e permeável à estimulação artística que poderá emergir o material para a performance, independentemente de quais regiões cerebrais estarão envolvidas.

Diante de tais considerações, o que justifica o estudo da neurocognição moderna para o trabalho do performer? Acreditamos, no esclarecimento que as novas tecnologias podem trazer sobre a construção de um relato, especialmente no que diz respeito ao trauma e a repressão, além da iluminação científica acerca da real cooperação entre as faculdades mediante a observação das zonas cerebrais que entram em atividade no trabalho criativo, o que não é pouco.

O trauma é por princípio uma vivência cuja intensidade trouxe um sofrimento maior do que o aparelho psíquico poderia suportar. Diante do fato traumatizante, ocorre um bloqueio de informações relacionadas à vivência, que pode ser imediato ou pode se construir ao longo dos anos (como no caso de presos expostos a sessões de torturas periódicas que entram em surto só de ouvir o caminhar de alguém calçando botas). 
A sucessão de traumas pode levar a um esquecimento crônico e patológico de momentos importantes da história do indivíduo, sem os quais se compromete a própria formação de sua identidade. Pessoas que sofreram experiências traumáticas na infância incorrem involuntariamente ao esquecimento como mecanismo de defesa em situações que seriam minimamente estressantes para um indivíduo sem traumas, o que nos revela que o exercício da lembrança é por si só um sofrimento insuportável para o traumatizado.

O mapeamento cerebral e as tomografias e ressonâncias magnética e nuclear permitem identificar quais áreas do cérebro estão comprometidas com o trauma e com o esquecimento em geral. A partir dessa identificação, torna-se mais fácil definir o tipo de tratamento químico para cada indivíduo, além das terapias de apoio (que, sozinhas, nem sempre resolvem casos mais avançados). Tais exames revelam também a ausência ou excesso de substância químicas envolvidas nesses processos, o que permite a aplicação correta dos remédios contra-balanceadores.

Nesse âmbito, de curar as patologias mais profundas relacionadas à memória, é que encontramos a ponte imediata e comprovadamente possível de ser estabelecida entre a neurobiologia moderna e a criação do performer, sem corrermos o risco de especulações pseudo-deterministas. Se o esquecimento é o principal destruidor de nossos relatos, e a memória, a matriz de toda a criação, a neuroquímica moderna pode objetivamente resgatar repertórios e libertar canais mnemônicos que antes de conduzirem à produção artística, reintegram a saúde mental do indivíduo, e o colocam em melhor disposição para a criação. 


\section{PARTE 2 - Da faculdade ao fluxo: a memória como recriação do vivido}

Iniciamos nosso trabalho introduzindo ao leitor uma genealogia, tão sintética quanto possível, do estudo da memória em algumas das mais representativas tradições do pensamento humano desde a antigüidade até a era moderna. Pretendemos, com tal apresentação, esclarecer como chegamos ao estatuto ontológico da atividade mnemônica assumido pelas ciências e pela filosofia na contemporaneidade, e, ao mesmo tempo, revelar que a problemática envolvendo a polaridade retenção/ criação é tão antiga quanto a filosofia clássica. Tal problemática não poderia ser resumida em linhas gerais na nossa tese, pois abarca precisamente o conjunto de questões que dizem respeito à formação do conceito de depoimento pessoal que desejamos construir.

Até então, portanto, observamos como a memória foi analisada e posicionada pelo pensamento humano até a modernidade: uma função de atributos claramente delimitados, a faculdade da retenção (ainda que, como já vimos anteriormente, a teoria humeana abra espaço para revisões mais arrojadas nesse sentido, como aquela empreendida por Deleuze e resgatada no segundo capítulo da primeira parte). O depoimento pessoal é um enigma de difícil solução para tais teorias, pois demanda a combinação de conteúdos da memória, da percepção e da imaginação em operações que tensionam as fronteiras de ação estabelecidas para delimitar as faculdades arborescentes. O substrato teórico que permite sua explicação só surgiria no final da era moderna, mais especificamente, na filosofia do século XX, em que os limites entre as artes, a psicologia e a filosofia foram irreversivelmente colocados à prova. 
A partir das considerações sobre tempo e movimento de subjetivação no tempo propostas por Henri Bergson, nos aproximamos da base filosófica que efetivamente sustenta e justifica a hipótese de nossa tese. Na teoria bergsoniana, a memória está formalmente assumida como criação, cuja perspectiva supera tanto a abordagem retentiva que marca o pensamento moderno emergente, como a teoria da reminiscência no inatismo platônico e as especulações racionalistas e empiristas. A memória é levada à fronteira da percepção e da imaginação pela observação da ação no tempo e de nossa relativa compreensão sobre este, até que seus limites funcionais sejam revistos por outros critérios externos às suas atribuições.

A atividade mnemônica se dá na sua prolongação com o presente, dada na experiência atual. Em parte, ela consiste em todos os conteúdos detalhadamente registrados, armazenados pelos sentidos e selecionados pelos afetos: a memória em sua acepção clássica, como persistência do vivido. Mas ela também é criação quando se coloca em atividade para responder às necessidades do presente, oferecendo combinações de impressões como sínteses mais ou menos prováveis para a solução das questões.

Veremos como esse processo constitui a gênese da noção de memória não mais como evocação do passado fenomenológico, passível de todas as imprecisões que implicam em registrar algo que não está mais apresentado aos sentidos (a retenção) , mas como recriação permanente do vivido em circuitos permeáveis. Ou seja, podemos afirmar que, pela teoria bergsoniana, o estudo da memória encontra uma nova e consistente perspectiva que permite contemplar a natureza ativa e criadora da memória sem que precisemos creditar aos outros domínios da mente 
tal atividade. Mais do que isso, abre espaço para que pensemos a cooperação entre as faculdades em tal nível de interação que torna o próprio conceito de faculdade enquanto reduto operacional da mente obsoleto. Reconhecer a natureza criadora da memória significa admitir que a afetividade e a intelecção se combinam no trabalho sobre o tempo; é assumir o ser como intuitivamente criativo na maneira de administrar seus conhecimentos, e é esse olhar que Bergson nos oferece.

Ainda é possível, no entanto, identificar, em suas reflexões, não a ruptura, mas a superação em continuidade das tradições anteriores de estudo da memória pela preservação da premissa dualista, problematizada em um nível mais œomplexo do que nos pensamentos apresentados até então. Diferentemente do que identificamos na atitude filosófica pós-estruturalista e na teoria da comunicação cibernética, cujo paradigma conceitual oferece os subsídios por meios dos quais amadurecemos a noção de memória não mais como faculdade, mas como fluxo.

Deleuze, Guattari, Éric Alliez e Pierre Lévy retomam as premissas bergsonianas para pensar a memória nos termos de presença e não-presença, e na simultaneidade dos fenômenos para além do todo dualismo, no campo das multiplicidades e das suspensões ativas. A existência e seus eventos são tomados na perspectiva multidimensional e não transcendental, em que matéria e potência são instâncias paralelas de uma mesma entidade em devir. O universo não está mais disposto em termos de experiência e transcendência, aqui/ agora e além, mas como plano de consistência das multiplicidades concomitantes que forma o mapa fluido de estratos erizomas.

Essa nova cartografia filosófica impõe uma revisão completa não só dos conteúdos que atribuímos aos conceitos, mas igualmente das formas que tais 
conceitos adquirem quando se privilegia a flutuabilidade da relação sobre a concretude da significação. O tempo e o espaço ganham novos sentidos pela dinâmica das relações rizomáticas do plano. Tudo que reconhecemos como essência ou estrutura são adensamentos temporários de ordens diversas, compreendidos na transitoriedade do devir. Os seres não são indivíduos, mas um conjunto de estratos móveis em conexão intensa com outros conjuntos de estratos, criando uma grande rede de inteligências afetivas, orgânicas, morais, moleculares. etc. A memória, o corpo etodas as faculdades humanas compreendidas até então são redefinidas pela complexidade das relações do fluxo em que virtual e atual surgem como operadores substitutivos para a polaridade corpo- espírito.

Apresentamos, pois, o quadro teórico pelo qual fundamentamos a natureza criadora e processual da memória. O depoimento pessoal encontra a abordagem que efetivamente contempla a complexidade e multidisciplinariedade que envolve sua formação. Veremos que o depoimento é exatamente a memória criadora atualizada pelas forças naguais e tonais específicas de cada processo criativo. A qualidade do depoimento, sua expressão cênica, sua disposição global enquanto obra, estão absolutamente comprometidas com a maneira como os virtuais de memória são pressionados para a atualização em cada processo.

Os agenciamentos que envdvem a criação de uma personagem são pouco semelhantes àqueles que produzem uma performance como Ritmo $\mathrm{O}$, de Marina Abramovic, ou à exposição de um testemunho em vídeo-depoimento, criações que desejam suprimir a fábula de seus relatos. Os diferentes processos conduzem a maneiras particulares do pelas quais o performer expõe sua história pessoal, e atestam, precisamente, a enorme capacidade criadora que a memória nos oferece. 


\section{Capítulo I - A mnemo- criação perceptiva em Bergson}

Dentre os filósofos modernos, destacamos Henri Bergson do capítulo anterior basicamente por que, em sua obra, a memória não é um apêndice da teoria do conhecimento em suas possíveis relações, mas um objeto qualificado para observação per se a partir de cujo estudo se pode construir outra perspectiva verdadeiramente inovadora acerca das relações corpo-espírito além das que já vimos até aqui. De fato, será com Bergson e sua revisão sobre as fronteiras dos atributos das faculdades e sua relação com a extensão que o conceito de memória criadora que desejamos construir para compreendermos o funcionamento do corpo-memória na performance ganhará fôlego e sustentação. No pensamento bergsoniano, os limites entre percepção e memória, e entre memória e imaginação se desfiguram e derrubam a idéia de pureza das funções arborescentes à luz de uma abordagem dos processos não mais por concepções exteriores a respeito de seus locais e funções, mas pela manipulação de vetores internos aos conceitos, tais como tempo, espaço e corporalidade.

Em sua principal obra de referência sobre o tema, Matéria e Memória, Bergson inicia o primeiro capítulo, a análise da seleção das imagens, endossando a conclusão com que encerramos nossas reflexões sobre o empirismo no capítulo anterior:

\footnotetext{
"Na verdade, não há percepção que não esteja impregnada de lembranças. Aos dados imediatos e presentes de nossos sentidos, misturamos milhares de detalhes de nossa experiência passada. $\mathrm{Na}$ maioria das vezes, estas lembranças deslocam nossas percepções reais, das quais não retemos mais do que algumas indicações, simples "signos" destinados a nos trazer à memória antigas imagens." 68
}

${ }^{68}$ Op. Cit., p. 30. 
Partamos, pois, de uma contribuição fundamental de Bergson ao associacionismo de Hume: o papel da consciência. A consciência está no cerne da passagem do objeto puramente existente a um objeto percebido e transformado em representação. É por esta que escolhemos da totalidade de ações percebidas aquelas que podem ser representadas, fenômeno que, se por um lado amplia em muito a noção do "percebido" (não mais uma imagem fotográfica, mas uma multiplicidade de imagens sensoriais para cada qualidade do vivido ${ }^{69}$ ), por outro estabelece um critério de seleção que qualifica a atividade perceptiva. Representar é, portanto, qualificar subjetivamente o percebido. Em outras palavras:

\begin{abstract}
"Isso equivale a dizer que há para as imagens uma diferença de grau, e não de natureza entre ser e ser conscientemente percebidas. A realidade da matéria consiste na totalidade de seus elementos e de suas ações de todo o tipo. Nossa representação da matéria é a medida de nossa possível ação sobre os corpos; ela resulta da eliminação daquilo que não interessa a nossas necessidades e, de maneira mais geral, nossas funções. Num certo sentido, poderíamos dizer que a percepção de um ponto material inconsciente qualquer em sua instantaneidade, é infinitamente mais vasta e mais completa que a nossa, já que esse ponto recolhe e transmite ações de todos os pontos do mundo material enquanto nossa consciência §́ atinge algumas partes por alguns lados. A consciência, no caso da percepção exterior, consiste precisamente nessa escolha. ${ }^{\prime 70}$
\end{abstract}

Essa noção de representação como síntese seletiva (e não apreensão passiva/generalizada-generalizante) da experiência abre novos caminhos para se pensar opapel dos afetos. Em Bergson, não é na imaginação enquanto nicho de operação isolado que serão recombinados os elementos da

\footnotetext{
69 "Mas como não ver que a fotografia, se fotografia existe, já foi obtida, já foi tirada no próprio interior das coisas e de todos os pontos do espaço? Nenhuma metafísica, nenhuma física pode mesmo furtar-se a essa conclusão. Componha-se o universo com átomos: em cada um deles faz-se sentir, em qualidade e em quantidade, variáveis conforme a distância, as ações exercidas por todos os átomos da matéria. Com centros de força: as linhas de força emitidas em todos os sentidos por todos os centros dirigem a cada centro as influências do mundo material inteiro. Com as mônadas: cada mônada, como o queria Leibniz, éo espelho do universo". Op. Cit., p. 36.

${ }^{70}$ Op. Cit., pp. 35-36.
} 
percepção/ entendimento com os conteúdos afetivos. A percepção é cada vez menos um aprendizado "puro", do quais podem se extrair informações sobre a forma de impressão objetiva. Os próprios sentidos, a extensão, o corpo reverbera o afeto e atua já no instante mesmo da vivência dos sentidos. Como vemos a seguir:

\begin{abstract}
"Mas esperamos precisamente mostrar que os acidentes individuais estão enxertados nessa percepção impessoal, que essa percepção está na própria base do nosso conhecimento das coisas, e que por havêla desconhecido, por não a ter distinguido daquilo que a memória acresce ou suprime nela, que se fez da percepção inteira uma espécie de visão interior e subjetiva, que só se diferenciaria da lembrança por sua maior intensidade."71
\end{abstract}

A percepção é naturalmente lacunar. Se somos incapazes de apreender o todo do universo na efemeridade do "presente" dividido nas unidades arbitrárias quaisquer que consideremos, e por isso nos valemos da consciência para escolher afetivamente o que e o como perceber, então se faz essencial uma outra qualidade do ser que permita preencher essas lacunas da percepção presente com o passado vivido: a memória. Ela cria uma endosmose com a percepção pela incisão da consciência, ocupa os espaços das impressões presentes com outros registros afetivos-informativos, cria uma terceira potência criadora em devir 72 .

Bergson define duas estratégias para essa combinação. A primeira se dá quando as lembranças contaminam imediatamente o presente, formando-lhe uma espécie de "fundo de percepção imediata." 73 A segunda é quando a memória opera uma pressão sobre todas as impressões passadas e dela extrai uma evocação que se

\footnotetext{
${ }^{71}$ Op. Cit., pp. $30-31$.

72 “O papel teórico da consciência, na percepção exterior, dizíamos nós, seria o de ligar entre si, pelo fio contínuo da memória, visões instantâneas do real. Mas, na verdade, não há jamais instantâneo para nós. Naquilo que chamamos por esse nome, existe já um trabalho de nossa memória e, conseqüentemente, de nossa consciência, que prolonga uns nos outros, de maneira a captá-los numa intuição relativamente simples, momentos tão numerosos quanto os de um tempo infinitamente divisível.”. Op. Cit. p. 73.

${ }^{73}$ Op. Cit.p. 31.
} 
irrompe sob a forma de evento ou de subjetividade acerca do vivido 74 . Em ambas, notamos que a separação das categorias tornou-se uma medida muito mais de direito do que de fato, pois na dinâmica das sínteses mnemo-perceptivas já não é mais possível distinguir com clareza os produtos do presente e do passado, da informação e da afecção 75 , tudo é recriação do vivido: “A verdade é que a afecção não é a matéria-prima de que é feita a percepção, é antes a impureza que aí se mistura."76 (entendendo como já estando nessa mistura também a memória).

Memória e percepção tornam-se movimentos do ser em conhecimento. O corpo é a fronteira entre passado e futuro, e o passado pressiona o presente pelas condições do presente, de onde Bergson conclui que o passado sobrevive no corpo (como delimitação espacial do presente) de duas maneiras: em mecanismos motores e em lembranças independentes. O corpo é o limite que presentifica. Mas, paradoxalmente, ilustra pelos dispositivos de sua memória, o deslocamento no tempo:

\begin{abstract}
"Mas já agora podemos falar do corpo como de um limite movente entre o futuro e o passado, como de uma extremidade móvel que nosso passado estenderia a todo momento em nosso futuro. Enquanto meu corpo, considerado no instante único, é apenas um condutor que se interpõe entre os objetos que o influenciam e os objetos sobre os quais age, por outro lado, colocado no tempo que flui ele está sempre situado no tempo preciso onde meu passado vem expirar numaação." ${ }^{\prime 7}$
\end{abstract}

\footnotetext{
${ }^{74}$ A percepção, aqui, está muito mais ligada aos estímulos que cada núcleo percebido propõe ao espírito e que provocam um movimento de projeção, de contra -atuação do espírito sobre o externo, do que aos fatos ou eventos por si. Como vemos adiante: "Quantos forem os fios que vão da periferia ao centro, tantos serão os pontos do espaço capazes de solicitar minha vontade e de colocar, por assim dizer, uma questão elementar à minha atividade motora: cada questão colocada é justamente o que chamamos percepção." Op. Cit. p. 44.

${ }^{75}$ Como veremos no capítulo seguinte, dependendo da atividade artística desenvolvida, os compromissos históricos cobrarão um maior ou menos rigor na depuração dos conteúdos informativos, como no caso da literatura de testemunho.

76 Op. Cit. p. 60.

${ }^{77}$ Op. Cit. pp. 8485.
} 
Assim, o reconhecimento se dá ora automaticamente, ora pelo esforço do espírito, mas em ambos como processo do ser inteiro, e não de faculdades isoladas que operam enquanto outras repousam. Isso seria inconcebível já que no desencadear das vivências se forma imediatamente a teia de cooperação da criação mnemo-perceptiva em devir:

“Contudo, um leve esforço de atenção revelar-me-ia que não há afeto, não há representação ou volição que não se modifique a todo instante; se um estado de alma deixasse de variar, sua duração deixaria de fluir [...] a verdade é que mudamos sem cessar e que o próprio estado já é mudança [...] cada um deles (pontos de atenção pelos quais percebemos a vida) não é senão o ponto mais bem iluminado de uma zona movente que compreende tudo o que sentimos, pensamos, queremos, tudo o que somos, enfim, num determinado momento. É essa zona inteira que, na verdade, constitui nosso estado. Mas de estados assim definidos, pode-se dizer que são elementos distintos. Continuam-se uns aos outros num escoamento sem fim." 78

O sujeito é uma zona de estados diferenciados, mas que se contaminam, invadem, retro-alimentam, derivam, devém, sem, contudo, perder necessariamente sua individualidade original. Uma nova abordagem a respeito da ação do tempo é fundamental para se compreender essa perspectiva e seu efeito na produção da memória complexa proposta pelo filósofo.

Bergson divide a memória em duas categorias autônomas segundo critérios de atividade e passividade que nos remetem novamente à Platão, mas com outros nexos funcionais. Uma qualidade se refere à retenção como já a apresentamos, ou seja, à capacidade de armazenar todos os eventos e objetos apreendidos com todas suas particularidades ${ }^{79}$ formando um grande histórico pessoal das percepções já

\footnotetext{
${ }^{78}$ Memória e Vida, I. A Duração e o Método. a) Natureza da Duração. 1. A duração como experiência psicológica, pp 2-3.

${ }^{79}$ É interessante observar que as pesquisas sobre lesões cerebrais à sua época levaram Bergson a formular conclusões bastante particulares sobre o fenômeno do esquecimento. Para ele, tratava-se invariavelmente da danificação não das memórias em si, mas da capacidade de associar as imagens-lembrança ao presente, como
} 
problematizadas pelas implicações dos afetos. São as imagens-lembranças, as quais nos acompanham permanentemente, mas só vêm ao nosso auxílio em situações involuntárias, por conexões misteriosas com o presente. Tais lembranças estão localizadas na ordem do tempo em que foram fixadas e, portanto, estão "intactas" protegidas pelos conteúdos históricos que a cercam: “A lembrança espontânea é imediatamente perfeita; o tempo não pode acrescentar nada à sua imagem sem desnaturá-la, ela conservará para a memória seu lugar e sua data."80

Mas há uma outra classe de memória que encontra em seu trabalho no tempo a diferenciação com a evocação espontânea, e a lança ao campo das sínteses de conhecimento propriamente ditas. É a memória de percepções que se prolongam com mais potência nas ações presentes pela afirmação de sua funcionalidade no presente, a que Bergson denomina reconhecimento. O reconhecimento é uma memória motora, da ação, que atualiza impressões para resolver o presente, oferecendo ao sujeito novas sínteses de pensamento a partir do vivido, permitindo que se criem soluções pela produção de novos conteúdos na tensão com as problemáticas atuais. Uma memória que imagina, enquanto a primeira apenas repete:

“[...] mas uma memória profundamente diferente da primeira (a retentiva), sempre voltada para a ação, assentada no presente e considerando apenas o futuro. Esta só reteve do passado os movimentos inteligentemente coordenados que representam seu esforço acumulado; ela reencontra esses esforços passados não em imagens-lembrança que os recordam, mas na ordem rigorosa e no caráter sistemático com que os movimentos atuais se efetuam. A bem da verdade, ela já não nos representa o nosso passado, ela o encena; e, se ela merece ainda o nome de memória já não é porque conserve imagens antigas, mas porque prolonga seu efeito útil até o momento presente. Dessas duas memórias,

uma falha no caminho da percepção, mas não nos conteúdos em si. Vemos no capítulo anterior que o mapeamento cerebral nos revela realidades outras sobre esse assunto.

${ }^{80}$ Matéria e Memória, pp. 90-91. 
das quais uma imagina e a outra repete, a segunda pode substituir a primeira e freqüentemente até dar a ilusão dela." "81

Chegamos à essência do conceito de memória como criação, para além de todas as atribuições que os projetos filosóficos revistos até agora podem sugerir. Evidentemente, devemos muito a eles, em particular aos pensamentos platônico e empirista que nos legaram a idéia de recordação/ação e de sujeito físico respectivamente, entre outras questões. Porém, é pela reflexão de Bergson que as faculdades são avaliadas por novos critérios operacionais a partir dos quais é possível encontrar limites e sentidos que extravasam suas funções inicialmente definidas.

A utopia do presente é substituída pela consciência do fluxo efêmero e potente do universo, condensação do Cosmos (numa perspectiva leibniziana) em unidades de percepção, multiplicidade do representado e do não-representável. A memória torna-se a percepção no tempo, mas também a criação nesse tempo pelas necessidades do presente, exigindo o afeto como escolha, necessariamente.

\begin{abstract}
"Portanto, é em vão que se tratam as imagens-lembranças e idéias como coisas acabadas, às quais se a tribui a seguir um lugar em centros problemáticos. Por mais que se disfarce a hipótese sobre uma linguagem tomada de empréstimo à anatomia e à fisiologia, ela não é mais que a concepção associacionista da vida do espírito; leva em conta apenas a tendência constante da inteligência discursiva a separar todo progresso em fases e a solidificar em seguida essas fases em coisas; e, como ela nasceu, a priori, de uma espécie de preconceito metafísico, não consegue
\end{abstract}

\footnotetext{
${ }^{81}$ Op. Cit. p. 89. Essa é uma divisão "pura” que Bergson logo admitirá como circunstancial. Existe uma série de estados intermediários entre os tipos de memória que definem relações específicas do cérebro com o corpo. Não nos estenderemos demais sobre as classificações de tais estados (como o déja vu e o decorar) para não nos desviarmos da noção de criação que é a chave da aplicação do pensamento bergsoniano em nosso estudo. Entretanto, cabe distinguir um importante aspecto: as imagens-lembrança são a base informativa do reconhecimento atento (pois também pode existir um reconhecimento desatento, cujas etapas de operação não são verificadas pela consciência ), alimentado-o com os conteúdos preservados. Para maiores detalhes sobre a conexão entre as memórias, ver capítulo 2, Do Reconhecimento das Imagens, III. Passagem gradual das lembranças aos movimentos. O reconhecimento e a atenção. Matéria e Memória; e também o capítulo II. A memória ou os graus coexistentes de duração, em Memória e Vida.
} 
nem acompanhar o movimento da consciência nem simplificar a explicação dos fatos." ${ }^{\prime 2}$

Aqui, encontramos a base da memória como recriação do vivido. Uma recriação que se dá não pelo deslocamento do sujeito para o passado, mas pelo prolongamento ativo do passado no presente pelas demandas desse presente. Se o corpo é o limite do tempo e do espaço, a criação mnemônica é a dilatação possível e o re-posicionamento permanente de tais vetores pelo confronto da experiência atual com a experiência já vivida, tomando "experiência" não mais na acepção de Hume, mas como a "zona" a que Bergson remete na citação transcrita anteriormente.

Portanto, a diferença entre memória retentiva (imagem-lembrança) e memória ativa (reconhecimento, síntese criadora) está também no local em que tal processo se efetua, o que nos abre caminho para pensar a atualização e a virtualização como novos condutores do real, como faremos no capítulo seguinte. Por ora, é suficiente retomarmos que a memória só pode ser criadora em função das exigências do presente, e que mesmo essa idéia de presente é inapreensível como instante, senão enquanto movimento no espaço. Esclarecida a premissa, expliquemos mais detalhadamente o trânsito das informações.

Há um aspecto sobre a percepção em Bergson que, em certa medida, é tributário da perspectiva empirista clássica. A percepção não é só a apreensão (representativa ou não) aferente do exterior, mas a reflexão eferente da imagem sintetizada, na complexidade de operações já descrita, no corpo, e daí pra o entorno. Em outras palavras: étambém a volta da imagem subjetivada à extensão e

\footnotetext{
${ }^{82}$ Matéria e Memória,p. 145.
} 
ao espaço externo. É essa percepção que atua que permite compreendermos os movimentos do corpo espírito pelo tempo como a teoria nos propõe, e que sustenta a proposta da memória como criação.

A experiência presente é a estimulação permanente do ser pelo exterior em todos os âmbitos possíveis. Perceber já é devolver ao meio as respostas possíveis e, acima de tudo, preferíveis a tais provocações sob a forma de novas provocações. Imprimir pressupõe marcar, invadir, desterritorializar o sujeito e receber as contrapartidas da invasão, que são as contra invasões ao ambiente externo. Portanto, a percepção não pode mais ser apenas impressão do mundo no corpoespírito, mas contra-impressão do corpo-espírito no mundo. Um movimento de recepção e reflexão no tempo e no espaço que transfigura as fronteiras entre sujeito e meio, entre corpo físico como presentificação e ser-no-fluxo pelas percepções reflexivas. Sujeito em devir e exterior em devir pelas particularidades da experiência e pelas escolhas que formam a memória ativa.

O reconhecimento atento, aquele que pode ser compreendido verdadeiramente como uma operação de síntese, pois implica na identificação consciente das imagens-lembranças relacionadas e na tomada de posição sobre os fatos que constroem a memória, cria um circuito de associações em que o objeto vai se revelando cada vez mais profundamente à medida que a memória lhe preenche pela dinâmica de evocações. Lembremos que cada objeto (ou evento) é uma questão que provoca a memória, exige respostas às suas "incompletudes", às suas dubiedades, às suas lacunas: ao não dado no dado.

Para Bergson, esse espaço onde reside a memória não é uma linha de passado, mas um caldeirão em fluxo. Cada "questão", como agora a entendemos, 
pressiona o todo da memória, sem que haja alguma linearidade arbitrária apriorística de seleção, de onde nasce a imagem do cone de Bergson.

No cone, a parte mais aberta se direciona ao espaço da memória que não está no corpo (pois também esse é uma imagem), mas que passa por ele, e abarca todos os seus conteúdos. Este vai afunilando ate encontrar um ponto específico do presente, que chamaremos $\mathrm{P}$, representado por um plano. Vemos que o gráfico do trânsito não é uma linha em que as imagens se organizam umas atrás das outras, mas um grande universo de imagens misturadas que é internamente pressionado até que de lá se expresse algum material e não outro 83 .

Essas lembranças, porém, se relacionam de forma particular dentro do cone. Considerando uma imagem como um segmento $\mathrm{AB}$ que vai de uma lateral a outra da figura, temos diversos segmentos com qualidades diferentes conforme a proximidade ou afastamento em relação ao vértice de pressão do presente. Esses novos segmentos, que seriam $\mathrm{A}^{\prime} \mathrm{B}^{\prime}, \mathrm{A}^{\prime \prime} \mathrm{B}$, , sucessivamente, estão cada vez mais afastados do corpo físico (as experiências motoras e sensoriais) e, conseqüentemente, da imagem $\mathrm{AB}$ original. São recriações do vivido por meios de novas combinações da memória a partir dos conteúdos da experiência sensóriomotora vivenciada no ponto $\mathrm{P}$, os desdobramentos da ação da memória criadora.

Retoma-se a perspectiva associacionista, mas com critérios mais claros sobre a seleção dos materiais. É evidente que todas as percepções se relacionam por similaridade, contigüidade, causa e efeito, ou seu negativo, e que daí nasce a capacidade do espírito de estabelecer generalizações e abstrair diferenças. Mas são

\footnotetext{
83 "O erro constante do associacionismo é substituir essa continuidade do devir, que é a realidade viva, por uma multiplicidade descontínua de elementos inertes e justapostos.”. Op. Cit., p. 157.
} 
as necessidades do presente que definem seus objetos e solicitações, mediados e interpretados pelos afetos.

Nesse processo, o turbilhão do cone se movimenta simultaneamente em dois sentidos. Um deles forma o grande giro das imagens entre si, em que todo o universo de conteúdos mnemônicos se dispõe para resolver a questão levantada em P. Em outro, as associações se contraem sobre si, imagem sobre imagem, de um âmbito mais especulativo, livre da percepção e distante (a boca do cone) até retornar ao presente $\mathrm{P}$, mais próximo da percepção em si, da atividade sensóriomotora que delimita o real pela apreensão do dado. Tal fenômeno se cria para apresentar, dentre os conteúdos possíveis, aqueles mais funcionais:

"Tudo se passa, portanto, como se nossas lembranças fossem repetidas um número indefinido de vezes nessas milhares e milhares de reduções possíveis de nossa vida passada. Elas adquirem uma forma mais banal quando a memória se contrai, mais pessoal quando se dilata, e deste modo participam de uma quantidade ilimitada de sistematizações diferentes."84

${ }^{84}$ Op. Cit., p. 198. 
Pelo gráfico do cone, podemos visualizar como a memória navega entre o que tomaríamos inicialmente como categorias antípodas no mapa do entendimento humano: a percepção pura e a imaginação criadora. Bergson nos oferece uma estrutura que ilustra ejustifica um entendimento da memória como deslocamento, tanto no tempo do corpo como no espaço das faculdades humanas, em "graus de comprometimento" com alguma veracidade histórica da experiência concreta pela proximidade ou afastamento da questão $\mathrm{P}$, elaborada no plano do presente.

É a urgência da questão presente que provoca o movimento e indica a necessidade de contração das vivências memorizadas para produzir uma resposta, mas os pormenores da subjetividade que determinam as soluções não podem ser dissecados, são criados no turbilhão. A questão $\mathrm{P}$, de fato, muitas vezes demanda um deslocamento radical para a boca do cone em busca de soluções mais complexas, que envolvem memórias mais remotas ou abstratas, cujas sínteses a percepção imediata não dá conta de solucionar.

O estudo sobre a natureza e o funcionamento da memória como devir criação oferece uma alternativa conceitual a um pensamento que nos parece utópico a respeito da existência de faculdades isoladas no espírito, estando umas ligadas exclusivamente ao concreto da ex periência sensorial e outras à abstração da fantasia. É mais plausível que a experiência se dê em planos de aproximação e distanciamento do presente, e que o ser humano tenha desenvolvido diferentes mecanismos psico-físicos para lidar com o volume de conhecimento como nos é apresentado na complexidade do movimento temporal-espacial, aos quais convencionamos denominar faculdades:

"Seria colocarmo-nos na duraç ão pura, cujo decorrer é contínuo, e onde passamos, por gadações insensíveis, de um estado a 
outro: continuidade realmente vivida, mas artificialmente decomposta para a maior comodidade do conhecimento usual." 85

Nessa perspectiva, corpo é a imagem que delimita e conforma o espírito, em outras palavras, que o torna presente. Tal delimitação se dá objetivada pelas circunstâncias do presente. Daí que todas as atribuições do espírito passam pelo corpo, e uma hierarquia entre estas não é mais possível. Há ainda o dualismo, em que o corpo seleciona as representações e as lembranças (mas não as armazena), mas não gera estados intelectuais diretamente, porém é um dualismo que já não fixa incontestavelmente as funções e privilegia a ação, a consciência da associação como o estar em fluxo pressionado pelas necessidades do plano, o contato que provoca as identidades.

Os processos humanos são, pois, abordados pela ação do tempo, espaço e corporalidade. Vemos que as sensações são os atributos que fixamos, que destacamos e extraímos da volatilidade dos acontecimento e aos quais retornamos como referência para qualificarmos as coisas. Os movimentos são a percepção no espaço, sempre divisíveis, sempre em ação. O fato é que, no fluxo das vivências, os movimentos carregam as sensações e às apresentam à consciência como fenômenos também dinâmicos, de onde se conclui que todos os movimentos não são tanto os transportes dos objetos, mas de nossos estados no tempo- espaço.

O ser-em- fluxo tem uma subjetividade líquida, que se constrói na chave da consciência sobre o devir, sobre a justaposição da fixação qualitativa das sensações com a intangibilidade quantitativa do movimento:

"Em suma, não há outra escolha: se nossa crença num substrato mais ou menos homogêneo das qualidades sensíveis é correta, só

${ }^{85}$ Op. Cit., p. 217. 
pode ser mediante um ato que nos faria captar ou adivinhar na própria qualidade algo que ultrapassa nossa sensação, como se essa sensação estivesse carregada de detalhes suspeitados e não percebidos. Sua objetividade, ou seja, o que ela tem a mais do que oferece, consistirá precisamente, então, tal como havíamos sugerido, na imensa multiplicidade dos movimentos que ela executa, de certo modo, no interior de sua crisálida."86

Pelo movimento, estabelecemos quantidades, unidades de durações, intervalos. Pelas sensações, definimos aquilo que ultrapassa, reaparece e se reafirma no movimento. "Perceber significa imobilizar" 87 Juntos, eles conduzem o sujeito pelo conhecimento no tempo e no espaço. Não é uma essência que se desloca, é o ser em si, já que esse deslocamento é condicionado e contido pelo corpo, de cuja experiência desencadeiam as operações sutis. As particularidades na percepção e organização de tais eventos caracterizam os sujeitos em devir, e a memória é a sistematização subjetiva dessas duas forças.

A memória reúne os objetos separados pela percepção e funda uma nova consciência de sujeito. Pela memória criadora, os espaços são revistos, os objetos e conceitos recriados, completados com outros sentidos, conectados em outras relações. O próprio limite físico se dilata pela criação de espaços numa dimensão que nasce da comunicação dos corpos para logo superá-la:

“Mas a separação entre a coisa e o seu ambiente não pode ser
absolutamente definida; passa-se por gradações insensíveis, de
uma a outro: a estrita solidariedade que liga todos os objetos do
universo material, a perpetuidade de suas ações e reações
recíprocas, demonstra suficientemente que eles não têm os
limites precisos que lhes atribuímos [...] - Pois bem, ao mesmo
tempo em que nossa percepção atual e, por assim dizer,
instantânea efetua essa divisão do material em objetos
independentes, nossa memória solidifica em qualidades sensíveis
o escoamento contínuo das coisas. Ela prolonga o passado no
presente, porque nossa ação irá dispor do futuro na medida exata

${ }^{86}$ Op. Cit., p. 240.

${ }^{87}$ Op. Cit., p. 244. 
em que nossa percepção, aumentada pela memória, tiver condensado o passado." 88

A memória define o ser na construção ativa do sujeito cognoscente pelo tempo. A percepção ativa/reflexiva transforma o corpo pela desterritorialização (invasão/ contra-invasão) sobre o espaço. A memória sobre a percepção estabelece novos nexos entre as unidades objetivas escolhidas pela percepção, e, assim, redefine a identidade do vivido em função de sua afetividade. Não são mais apenas as faculdades que tem suas fronteiras abaladas, mas é o sujeito que se faz fluxo no pensamento bergsoniano.

Bergson antecipa todo um entendimento do humano que substitui os antagonismos entre as funções, em especial aquele que se referiu por séculos à razão-imaginação, pela cooperação do ser em devir conhecimento. E se alguns pontos de sua teoria ainda permanecem condicionados ao dualismo corpo-espírito, que intimida um olhar mais expandido sobre a noção de corpo, aqui, apenas indicado, a revolução que operou na perspectiva de abordagem dos processos não deixa dúvida de que se funda uma nova etapa do estudo da memória, e se encontra uma ferramenta potente para compreender a arte.

${ }^{88}$ Op Cit., p. 247. 
Capítulo II - Virtual e atual, recordações de um Corpo sem Órgãos

Analisamos no capítulo anterior de que forma o pensamento bergsoniano dá corpo à abordagem dos processos mnemônicos numa perspectiva trans disciplinar que introduz o conceito de memória criadora a partir da observação do fenômeno como movimento e circunscrição do sujeito no tempo e espaço. Vimos que a memória não é o deslocamento para o passado, mas a re-criação do vivido no presente pelas condições do presente. Esse conceito é retomado e radicalizado pelo pós-estruturalismo, em que toda noção de essência, de delimitação do espírito pelo corpo que ainda existia até Bergson será substituída pelos cânones do corpo sem órgãos e do devir como síntese temporal-espacial.

No projeto pós-estruturalista, a dilatação dos termos que era sugerida e apontada pela teoria da memória de Bergson, mas que encontrava, no dualismo, seus limites epistemológicos, avança no entendimento do ser como fluxo. Corpo e alma são parte da dinâmica dos processos que organizam/desorganizam o universo, eles não sofrem mudanças, eles são mudança (como já antecipava Bergson).

A estabilidade da matéria e de certas estruturas morais, intelectuais, afetivas que permite com que intuamos nosso corpo e identifiquemos um conjunto metafísico que nos individualiza não são produtos de uma natureza em si teleológica, porém o resultado de agenciamentos queproduzem adensamentos com certas especificidades, mas que seguem em transformação. Os seres são compreendidos, em última instância, como estratos orgânicos, históricos, intelectuais, afetivos e morais em relação rizomática. Matéria e potência são 
instâncias com graus de pressão diferentes do mesmo fluxo que, pela variação na velocidade do movimento das partículas, cria e dissolve as formas de vida e de ser em vida.

Ilustremos a imagem de Corpo sem Órgãos como revista por Deleuze: ‘O CsO faz passar intensidades, ele as produz e as distribui em um spatium ele mesmo intensivo, não extenso. Ele não é espaço e não está no espaço, é matéria que ocupará o espaço em tal ou qual grau - grau que corresponde às intensidades produzidas [...] Matéria igual a energia."89

Corpos sem Órgãos, originalmente, foi uma metáfora criada por Antonin Artaud para expor e protestar contra a opressão embutida em todas as formas de atribuições de função, em toda ordem que delimita atividades, em todo órgão; não mais somente no âmbito das representações fisiológicas, mas também das relações de poder. O CsO como aplicado por Deleuze e Guattari não é um conceito que está nas coisas, mas uma prática pela qual podemos compreender a construção do que reconhecemos como ser, e, em nosso estudo, do que chamamos até aqui de memória: “o CsO não se opõe aos órgãos, mas a essa organizações dos órgãos que se chama organismo."90

Como vimos, aqui, o homem é, no pensamento deleuziano, o fluxo das intensidades. As intensidades movimentam os seres para determinadas zonas conforme a ordem dos desejos, projetam-lhes ao contato com o que também lhe procura para agenciar interesses, necessidades. Cria uma zona de instabilidade: desterritorializa e reconfigura os estratos. É pela potência dos desejos que os seres

\footnotetext{
${ }^{89} 28$ de novembro de 1947 - Como criar para si um Corpo sem Órgãos. In Mil Platôs Capitalismo e Esquizofrenia, Vol. 3. p. 13.

${ }^{90}$ Op. Cit. p. 21.
} 
se deslocam, e estabelecem os agenciamentos que os definem em determinado recorte temporal-espacial:

\begin{abstract}
“O prazer é a afecção de uma pessoa ou de um sujeito, é o único meio para uma pessoa 'se encontrar' no processo de desejo que o transborda. Os prazeres, mesmo os mais artificiais, são reterritorializações [...] trata-se de criar um Corpo sem Órgãos ali onde as intensidades passem e façam com que não haja mais nem eu nem outro, isto não em nome de uma generalidade mais alta, de uma maior extensão, mas em virtudes de singularidad es que não podem mais ser consideradas pessoais, intensidades que não podem mais se chamadas de extensivas." 91
\end{abstract}

Retomando a análise que apresentamos no segundo capítulo da parte anterior, a subjetivação proposta por Deleuze em sua releitura do associacionismo de Hume consiste no ultrapassamento do dado pela inferência e na capacidade de se criar novas soluções e entendimentos para o vivido pelas sínteses depuradas da imaginação. Vemos agora que tais movimentos se organizam em função da potência do desejo, que direciona o fluxo e seleciona os agenciamentos conforme seus critérios e necessidades. Desloca o ser para um devir específico, e não outro.

Nesse momento, cabe esclarecer mais detalhadamente a noção de fluxo deleuziana, ou, melhor dizendo, como se desenha o mapa do fluxo. Deleuze toma emprestado dois conceitos do livro de Carlos Castañeda Histórias de Poder para ilustrar a cooperação necessária entre uma força que comprime (saberes, matéria, etc) e outra que deriva e expande: o tonal eo nagual

“O tonal parece ter uma extensão disparatada: ele é o organismo, e também tudo que é organizado e organizador; mas eleé ainda a significância, tudo que é significante e significado, tudo que é suscetível à interpretação, à explicação, tudo que é memorizável sob a forma de algo que lembra outra coisa; enfim, ele é o Eu, o sujeito, a pessoa individual, social ou histórica e todos os sentimentos correspondentes. ${ }^{.92}$

\footnotetext{
${ }^{91}$ Op. Cit., p 18.

${ }^{9}$ Op. Cit., pp., 24-25. Grifos meus.
} 
O tonal é a força que estreita a relação entre as partículas até a formação dos estratos, que pressiona as velocidades do fluxo para formar conjunções específicas de $\operatorname{afectos}^{93}$, de matéria, de saber, em suma, de todas as atualizações que definem esse sujeito que ultrapassa e devém. Em outras palavras, é toda força que orienta e se refere aos estratos, determinando o deslocamento e as particularidades de sua formação. O nagual é a outra força formadora complementar, que pressiona os estratos para o fluxo rizomático e movimenta os devires. Também esse movimento tem na base os desejos que se criam e se assumem, pelos quais os estratos se conectam em uma identidade que já não é individual, mas processual, identidade de seres condensados em estratos e já desterritorializados em devir.

Um primeiro olhar pode nos fazer crer que a memória estaria apenas nos estratos, se estes pudessem ser extraídos como categorias isoladas no tempo e no espaço, mas sabemos que o pensamento deleuziano não permite nem sustenta essa possibilidade. Se os estratos de saber, de afeto e de representação definem a subjetividade dos seres, essa subjetividade já está em devir nos desejos da força nagual, se prolonga imediatamente por agenciamentos a outros estratos que têm suas memórias particulares em processo. Chegamos, em última instância, a uma noção de macro-memória construída no e pelo fluxo dos agenciamentos e pelos estratos em devir.

Quando falamos de desterritorialização nos referimos a um fenômeno que demanda o afrouxamento de ligações entre partículas e sua conseqüente expansão no espaço para se religar a outras partículas. Logo, trata-se de um processo físico, ou que tem uma dimensão física da qual parte para atingir outras instâncias.

${ }^{93}$ Afecto como poder de afetar. 
Exemplo: para mudar minha opinião sobre algo eu preciso vivenciar pelo corpo uma experiência que me coloque em um devir criação sobre o já vivido, e mesmo as sínteses abstratas pressupõe um movimento em nível molecular do estrato orgânico cérebro.

De fato, não podemos mais falar de movimento sem envolver as duas instâncias do fluxo: a matéria e a energia. A memória do sujeito que ultrapassa, a memória em devir, opera na dinâmica tonal e nagual simultaneamente, em que o corpo não pode mais ser compreendido apenas na dimensão da matéria. Cria-se uma grande memória dos estratos em devir, em que o corpo não é um mediador do espírito, nem o espírito o proprietánio da matéria.

O que percebemos como matéria são adensamentos orgânicos com qualidades em constante transformação pelas relações rizomáticas no grande deslocamento espaço-temporal não-teleológico do plano de consistência. A dinâmica das transições moleculares entre as duas instâncias do ser não é excêntrica ao plano e aos seus agenciamentos. Não há transœndência, portanto, não há corpo como matéria estática nem espírito como essência que escapa.

Vemos que a memória é a criação não mais de um sujeito que percebe, mas de um sujeito que supera a percepção, deriva, devém e é invadido. Ele não se dá apenas nas condensações dos estratos que o definem num recorte no tempo e no espaço, mas nas projeções extra-corporais, nas fronteiras diluídas, nos agenciamentos assumidos pela intensidade dos desejos. Aqui a noção de memória coletiva atinge o trans-humano: é da memória de um sistema que estamos tratando. 
Para melhor entendermos no que consiste essa noção de memória como parte do sistema de estratos e agenciamentos, mas também como potência em devir, falemos de dois conceitos-chave da filosofia de Deleuze e da cibernética de Pierre Lévy, os quais redefinem um terceiro, a realidade: atual e virtual. "Virtual” tem sua origem semântica no latim medieval virtualis, que deriva de virtus, força, potência, e, na Escolástica, significaria não só o que está em potência, mas o que necessariamente não se manifesta em ato.

Deleuze propõe um outro sentido para o virtual pela revisão precisamente dessa última atribuição, ou seja, o virtual é a potência que deseja ser ato, deseja a atualização. O virtual é o possível constituído em suspensão, mas não um possível como fenômeno estático, e sim um “complexo problemático [...] que chama um processo de resolução: a atualização."94 É realidade latente, consistente, organizada, autônoma, devinda, que aguarda pela efetivação das relações que lhe transportem da suspensão para atualização. Assim, o virtual não se opõe ao real, mas ao atual. Ele contém o real na névoa problemática de tensões e tendências que lhe identificam, mas cuja resolução não está contida aprioristicamente nessa névoa.

Esse é um ponto fundamental das relações de atualização, e que as distinguem da realização: elas são sempre criadoras. O virtual, a potência em desejo, contém e oferece as possibilidades de relação para definir o real, mas as formas de atualização não são dadas estruturalmente pela possibilidade. Cada estrato (e, já vimos, os seres humanos são um conjunto de estratos agenciados entre si e em relação rizomática) carrega suas virtualidades e organiza sua

${ }^{94}$ Op. Cit., 16. 
identidade precisamente na maneira como as atualiza e como recria novos virtuais. Às palavras de Lévy:

\begin{abstract}
"Por um lado, a entidade carrega e produz suas virtualidades, um acontecimento, por exemplo, reorganiza uma problemática anterior e é suscetível de receber interpretações variadas. Por outro lado, o virtual constitui a entidade: as virtualidades inerentes a um ser, sua problemática, o nó de tensões, de coerções e de projetos que o anima, as questões que o movem, são uma parte essencial de sua determinação. [...] A atualização aparece, então, como a solução de um problema, uma solução que não estava contida previamente no enunciado. A atualização é criação, invenção de uma forma a partir de uma configuração dinâmica de forças e de finalidades. Acontece, então, algo mais que a dotação da realidade a um possível ou que uma escolha entre um conjunto predeterminado: uma produção de qualidades novas: uma transformação das idéias, um verdadeiro devir que alimenta de volta o virtual. [...] O real assemelha-se ao possível, em troca; o atual em nada se assemelha ao virtual: respondelhe'95
\end{abstract}

Portanto, realizar é uma atividade essencialmente distinta de atualizar: enquanto a primeira adere ao provável para instaurar estados pré-definidos, a segunda cria soluções para todo tipo de questão pelo trabalho sobre o virtual como multiplicidade em suspensão. Porém essa solução manifesta, que é a atualização, gera novas questões, indica ou sugere outras saídas da rede, propõe outras situações que recolocam a entidade em devir, em suma, cria virtualizações.

E, aqui, novamente: virtualizar não significa desrealizar, pois não se trata somente da diluição do real em possibilidades imanentes. A passagem do atual para o virtual é um processo também de natureza criadora, irreversível, indeterminado e não-dado, que não remete a jogos de probabilidade e demanda a invenção como síntese das questões/ desejos em potência.

A questão da memória é problematizada ontologicamente em um grau que extrapola as teorias que abordamos até então, pois a localização das entidades não

${ }^{95}$ Op. Cit., pp. 16-17. 
se dá mais em uma linha de tempo unilateral (ou no máximo, bilateral) em que o cosmos se divide entre o planeta e a transcendência e as criações progridem por sucessão de relações binánias (o princípio do terceiro excluído na teoria da razão clássica). Todas as operações se constroem no plano e pelos múltiplos agenciamentos das entidades em devir, cuja organização forma um mapa fluído de platôs e rizomas que, levado às últimas conseqüências, se junta à física quântica para justificar uma existência simultaneamente virtual e atual dos seres:

\begin{abstract}
"A filosofia é a teoria das multiplicidades. Toda multiplicidade implica elementos atuais e elementos virtuais. Não há objeto puramente atual. [...] Com efeito, como mostrava Bergson, a lembrança não é uma imagem atual que se formaria após o objeto percebido, mas a imagem virtual que coexiste com a percepção atual do objeto. A lembrança é a imagem virtual contemporânea ao objeto atual, seu duplo, sua "imagem no espelho [...] Não é mais uma singularização, mas uma individuação como processo, o atual e seu virtual. ${ }^{.96}$
\end{abstract}

Entre a lembrança e a percepção está a intensidade do recorte temporal, a utopia do presente da maneira como desejemos delimitá-lo, como já vimos em Bergson. Mas lembrar não é apenas perceber no tempo expandido, há ainda outra diferença de natureza processual. Se a atualização e a virtualização são atividades criadoras, vemos a chave para um entendimento da memória como criação num sentido ainda mais amplo.

A memória não é somente o vivido trazido do passado para responder às necessidades presentes. Ela não se revela exclusivamente pelo que reconhecemos atualizado, pelo que está instaurado pela urgência da ação. Ela forma um espaço que contém tudo que se adensa na entidade, resiste, e que se coloca em um devir de criação, mas abarca igualmente os seus duplos virtuais simultâneos. A criação tem

\footnotetext{
${ }^{96}$ O Atual e o Virtual, Gilles Deleuze, in Deleuze Filosofia Virtual, pp. 49-53-54.
} 
suas próprias razões que não se submetem às regras de funcionalidade das demandas do presente. A memória é entendida no próprio âmbito das potências como virtuais (e não possibilidades) e das atualizações como sínteses (e não derivações quantitativas do provável), ou seja, na forma como já as apresentamos: em relações inventivas. Atual evirtual inseparáveis e coexistentes no tempo:

\begin{abstract}
"Mas em todos os casos, a distinção entre o virtual e o atual corresponde à cisão mais fundamental do Tempo, quando ele avança diferenciando-se segundo duas grandes vias: fazer passar o presente e conservar o passado. O presente é um dado variável medido por um tempo contínuo, isto é, por um suposto movimento em uma única direção: o presente passa na medida em que esse tempo se esgota. É o presente que passa que define o atual." $" 97$
\end{abstract}

Atualização e virtualização como movimentos criadores são os vetores que qualificam de forma mais complexa o entendimento do ser em construção cognoscente no tempo e no espaço. A individuação se dá exatamente nesse trânsito criativo, nas particularidades que o definem, nas escolhas, nos desejos, na afirmação ou negação de tendências, em suma, em tudo que resiste e se impõe na atualidade das relações.

O ultrapassamento está no reconhecimento do virtual como parte do real, do existente, e não como resíduo metafísico do que não se confirmou. Na consciência de que cada atualização é apenas uma face detectável das questões impostas pela potência processual dos virtuais, uma resposta ao possível que já se circunda simultaneamente da névœ de virtuais que emanam de seu adensamento, e a problematizam.

Uma noção de sujeito só pode ser tomada como: instâncias mais ou menos diluídas, e que por isso encontram alguma diferenciação, dentro do mapa ${ }^{97}$ Op. Cit., pp. 5455. 
rizomático. Os movimentos de atualização e virtualização não são homogêneos, mas radicalmente o oposto; e são suas particularidades no tempo e no plano que podem indicar uma possível subjetivação em rede. Esta se faz na construção dos estratos, pela ação das forças tonais, mas logo pelo ultrapassamento dos estratos de percepção, de memória, de afetos pelas forças naguais.

A memória é o resultado da ação das forças de individuação em nível atual e virtual simultaneamente e em devir. O âmbito da atualização nos permite reconhecer o indivíduo/ objeto do plano como presença, enquanto a virtualização configura a existência do mesmo indivíduo na não-presença, sendo ambas dimensões do ser real. $\mathrm{O}$ atual se desgasta para se reinventar no virtual e inserir melhor o ser na inteligência global do plano

Sua função e local estão absorvidos pelo fluxo e seus princípios de operação: a memória é resistência no estrato, mas já é imediatamente criação no tempo múltiplo do ser virtual/atual, que se extingue e se recria alternando aspectos sem abandonar a rede. Corpo e mente não são máquinas isoladas com estatutos e atributos naturalmente específicos. São dimensões do ser que se definem conforme a velocidade das forças e a intensidade dos desejos, que qualificam os agenciamentos e direcionam os devires.

Portanto, o pensamento cibernético e pós-estruturalista representa a superação definitiva das faculdades como delimitação apriorística dos processos que promovem o conhecimento e envolvem a experiência. O entendimento da memória como atributo, seja da instância que for e com a natureza que tenha, assim como todas as demais funções humanas apreendidas pelo pensamento arborescente, é digerido pela lógica maior de funcionamento do ser em devir, da 
mente expandida, da mente em rede. As relações entre as entidades, e seus movimentos no espaço e no plano, tornam-se os verdadeiros eixos para uma abordagem do ser em construção, e redefinem em outros níveis a ontologia da memória como criação.

O depoimento pessoal é a memória pressionada pelas forças de criação, o conjunto de atualizações produzido pelos agenciamentos específicos de cada processo. Nesse quadro de referência, está, de certa forma, superada a problemática da responsabilidade histórica do depoimento, uma vez que toda atualização já pressupõe em si uma relação de criação. Diferentes estratos qualificam a identidade do depoimento, e geram cenas cujas diferenças estéticas estão baseadas exatamente nas distintas formas de organizar o depoimento, como veremos na terceira parte da tese.

Tributamos, pois, a tais pensadores, a base filosófica que nos permitiu alicerçar uma reflexão mais consistente sobre a premissa da memória criadora, cuja dinâmica se insere, de fato, na lógica maior de relações que gerenciam a vida dos seres. 
Capítulo III - A crítica da consciência imaginativa

Chegamos aqui a um ponto em que se torna necessário submetermos nosso pensamento ao exame das disciplinas cuja crítica lhe diz respeito, para daí verificarmos sua efetiva aplicabilidade nos termos como odispomos. Buscamos na fenomenologia a interlocução potente para tanto não só porque alguns dos filósofos a ela associados já iniciaram essa crítica (Sartre, especificamente, em sua metafísica ingênua da imagem), mas por que, aqui, o conceito de imaginação remete a uma noção de processo essencialmente distinta da que apresentamos, e em um sentido que afeta profundamente a memória sem, no entanto, assumir seu comprometimento com a revisão das funções (pela forma como a imaginação é isolada arbitrariamente das consciências perceptiva e memoriosa: a retenção ea rememoração em Husserl).

A crítica sartreana incide sobre praticamente todas as filosofias que partem de uma perspectiva atomista da imagem. Todas as correntes de pensamento que tratam a imagem como um objeto produzido pelas faculdades, cujos conteúdos são de natureza variável e, portanto, se relacionariam às atividades de uma ou outra função. Em outras palavras, toda noção de imagem como impressão.

O primeiro ataque recai sobre Descartes, cujo projeto racionalista, na medida em que ainda precisava dar conta da problemática antiga e medieval da dupla existência (material e espiritual) dos seres e justificar a hierarquia das instâncias, cinde radicalmente as atividades mecânicas das atividades do pensamento, situando o corpo exclusivamente como motor das primeiras:

"A imagem é uma coisa corporal, é o produto da ação dos corpos exteriores sobre o nosso próprio corpo por intermédio dos 
sentidos e dos nervos. Matéria e consciência excluindo-se uma à outra, a imagem, na medida em que é desenhada materialmente e alguma parte do cérebro, não poderia ser animada de consciência, ela é um objeto tanto quanto os objetos exteriores. É exatamente o limite da exterioridade. A imaginação ou o conhecimento da imagem vem do entendimento; e o entendimento aplicado à impressão material produzida no cérebro, que nos dá uma consciência de imagem."98

A imagem é uma unidade de comunicação da percepção cuja verificação dos conteúdos não pode ser realizada em si, já que o processo é o mesmo para todo tipo de imagem, senão pelas operações da mente. Nesse sentido, ela se aproxima de uma noção de ilusão, de aparência, de engano derivada da fragilidade do aparato sensorial. Essa etapa do processo será revista pelas escolas imediatamente seguintes, sem, no entanto, que se transforme a noção de imagem como impressão.

O associacionismo de Leibniz representa, nesse sentido, um pensamento intermediário entre o racionalismo cartesiano e o empirismo de Hume no tratamento da imagem. A imagem é um signo, mas um signo elaborado não só pela excelência analítica da razão pura, nem pelas marcas dos objetos externos em um corpo pretensamente ignorante, mas por ambos; já que o corpo se apresenta sempre à alma para realização de seus processos e aí encontra sua inteligência. A imagem é um signo cuja relação com seu objeto é variável, da onde se afirma a existência de imagens de todo tipo: umas mais claras, outras mais confusas, conforme a qualidade de denotação. As idéias seriam as imagens mais elaboradas, que evoluem da confusão de imagens que se apreendem simultaneamente. Entre imagem e idéia, portanto, não há exatamente uma diferença de natureza, mas de qualidade de expressão. Ambas são, ainda, unidades do processo.

\footnotetext{
${ }^{98}$ A Imaginação, p. 39.
} 
A crítica maior recai verdadeiramente sobre o associacionismo de Hume, que, conforme Sarte, levaria ao limite a abordagem da imagem enquanto coisa, como um utilitário das faculdades, mais ativamente, da percepção:

\begin{abstract}
“Enquanto Leibniz, para resolver a oposição cartesiana imagem, pensamento, tende a desfigurar a imagem como tal o empirismo de Hume se esforça, ao contrário, por reduzir todo o pensamento a um sistema e imagens. Ele toma de empréstimo ao cartesianismo sua descrição do mundo mecânico da imaginação e, isolando esse mundo, por baixo do terreno fisiológico no qual ele mergulhava e pelo alto do entendimento, faz dele o único terreno sobre o qual o espír ito humano se move realmente. Não há no espírito nada mais do que impressões e cópias dessas impressões que são as idéias e que se conservam no espírito por uma espécie de inércia, idéias e impressões não diferem em natureza, o que implica que a percepção não se distingue a si mesma da imagem. "99
\end{abstract}

Para Sarte, a grande questão é o tratamento da imagem como objeto externo, como unidade impessoal, signo de percebido, ou signo da idéia, na razão; que, no máximo, encontra nos sentidos de seus conteúdos a conexão com a subjetividade. Esse pressuposto é radical para o empirismo. A imagem é vista como algo natural, como uma construção da percepção, quando para o filósofo existem implicações, por assim dizer, ônticas ${ }^{100}$, anteriores que não foram sequer tangenciadas.

E, por fim ${ }^{101}$, a crítica, bastante importante para nossa tese, do bergsonismo. Para Sarte, na medida em que elevou o mundo e todos seus objetos à categoria de imagem, Bergson instaurou uma consciência supra-subjetiva, cujas relações com as

\footnotetext{
${ }^{99}$ Op. Cit., p. 41.

${ }^{100}$ E não ontológicas, no sentido Heideggeriano.

${ }^{101}$ Com exceção de Leibniz, resumimos as ponderações de Sarte às tradições que resgatamos para nosso estudo, a fim de não prolongar desnecessariamente suas progressões sobre as incongruências dos outros pensamentos que tratam a imagem sob a mesma orientação. Ainda foram objeto de sua crítica a psicologia sintética, o associacionismo de Taine e mesmo a fenomenologia de Husserl em alguns aspectos. De fato, das cento e seis páginas do texto sobre a imaginação, as cem primeiras se dedicam exclusivamente à revisão de seus antecessores, e, como veremos, apenas nas cinco páginas finais Sartre irá sugerir um projeto de imagem como consciência que não se desenvolve.
} 
imagens não se constroem mais sob a particularidades da consciência, que produz representações específicas, mas como um gande movimento em que a própria criação das imagens já não dependeria das qualidades de seus correlatos: é um processo exterior:

\begin{abstract}
“Bergson considera negligenciável essa característica essencial do fato da consciência que é a de aparecer precisamente como consciente; e, por ter confundido o mundo com a consciência, tomada como uma qualidade quase substancial, também reduz a consciência psicológica a não ser mais do que uma espécie de epifenômeno, do qual pode se descrever a aparição, mas que não se explica. Em particular, como pode essa consciência inconsciente e impessoal tornar-se uma consciência consciente de um sujeito individual? E, como, tornando-se "presentes" as imagens virtualmente representadas, envolvem subitamente a existência de um 'Eu'?”102
\end{abstract}

E ainda, sobre a crítica da memória:

“Mas, se a consciência é definida por Bergson de uma forma vitalista, como uma atualidade resultante da atitude corporal, ela representa também, para ele a margem que separa a ação do ser atuante, o poder de escapar ao presente e ao corpo, a memória. De onde sua segunda orientação da teoria das imagens: a lembrança não é consciente apenas como presente, mas também como passado." 103

Vemos, portanto, que a crítica sartreana reclama da localização da imaginação nas teorias do conhecimento aqui citadas em termos muito semelhantes aos quais Edmund Husserl reclamou das psicologias que se debruçavam sobre os conteúdos da consciência sem verificar antes se a própria consciência não teria sua estruturas geradoras inatas, apriorísticas, transcendentais. Está em jogo a função da principal consciência fenomenológica: a consciência imaginativa.

\footnotetext{
102 Op.Cit., p. 55.

${ }^{103}$ Op. Cit., p. 58.
} 
A imaginação fenomenológica é a capacidade da consciência de fazer surgir objetos imaginários, que permite com que nos relacionemos tanto com o ausente quanto com o inexistente. Diferentemente da percepção, que oferece fragmentos do objeto, a imaginação cria objetos e eventos inteiros, seja pela fabulação que gera a fantasia, pelo preenchimento das lacunas do percebido ou pela analogia com outras imagens. Eis que a imagem é algo completamente diferente do objeto, que pode ou não guardar alguma identidade (do grego análogon: proporção, existência de algo comum em coisas que permite que haja alguma relação entre elas apesar das diferenças).

A imaginação é, assim, a consciência criadora maior na metafísica fenomenológica, pois através dela a consciência encontra seu sentido: construir as significações, afirmar o mundo como tal na produção dos sentidos, sentidos esses que são atribuídos por um sujeito que se estrutura na consciência transcendental e por meio dela descreve as experiências como atividades de conhecimento. A imagem como objeto representaria, em última instância, um desvio estrutural nas atribuições do ser consciente: a consciência seria tomada como objeto, reduzida às coisas às quais representa, quando deveria ela mesma gerar seus conteúdos pela atuação do sujeito dado pelas estruturas da consciência transcendental, e não o contrário. A imagem não é o seu objeto, não é seu significado, seu conteúdo. Essa é a mesma diferença que levou Husserl a separar a fenomenologia da psicologia, a última se ocupando do estudo dos objetos e a primeira das estruturas do psiquismo.

A imaginação é o processo de construção do sentido, a doação do sentido, a aplicação criativa da consciência do sujeito na invenção e definição das coisas. É a 
subjetivação em ação: "Ela não pode entrar na corrente da consciência a não ser que ela própria seja síntese, e não elementos. Não há, não poderia haver imagens na consciência. A imagem é um ato, e não uma coisa. A imagem é consciência de alguma coisa." 104

A questão de Sartre em muito se assemelha àquela que motivou Deleuze a rever a obra de Hume: como do dado devém um sujeito? Ou, nesse caso, como da ação devém um sujeito? Não haverá respostas possíveis enquanto a consciência for tomada como categoria apriorística de determinação do ser que prescinde tanto da psicologia como âmbito de estudo e delimitação do individual quanto dos objetos em si provedores de experiência. A consciência fenomenológica surge como uma esfera do ser que pensa as coisas de maneira ao mesmo tempo autônoma aos objetos transcendentais e completamente desinteressada dos aspectos afetivos, e condiciona as operações humanas aos esquematismos da consciência em ação.

Os desdobramentos de tal paradoxo no que tange ao estudo da memória e, especificamente, quando esse estudo se encaminha para construção de um conceito de memória como criação, estão mais flagrantes na principal obra de Husserl sobre a consciência no tempo. Em seu tratado Lições para uma Fenomenologia da Consciência Interna do Tempo, o termo memória aparece poucas vezes, ao contrário da consciência retencional, termo cunhado para explicar a consciência do passado. A consciência retencional não é a recordação em si dos eventos "percepcionados", mas a consciência de que existe uma dimensão abstrata do tempo à qual denominamos passado. Esclareçamos os conceitos:

'Se denominamos 'sentido' um dado fenomenológico que, através da apreensão, nos torna conscientes de algo objetivo

${ }^{104}$ Op. Cit., p., 106. 
como dado em carne e osso (Leibhaft), a que chamamos então objetivamente 'percepcionado', assim temos nós que distinguir também, no mesmo sentido, entre um temporal 'sentido' e um temporal 'percepcionado'. O último significa o tempo objetivo. Contudo, o primeiro não é ele próprio tempo objetivo (ou posição no tempo objetivo), mas antes o dado fenomenológico através da apercepção empírica do qual se constitui a referência ao tempo objetivo. Os dados temporais, ou, se quiser, os signos temporais não são os próprios tempora. O tempo objetivo pertence à conexão da objetividade da experiência."105

Husserl fala de dois tipos de experenciar: o inautêntico (uneigentlich) e o autêntico (eigentlich), sendo que o último se refere à experiência fenomenológica, ou seja, a experiência intuitiva das atividades da consciência pura no tempo. Tal atividade em nada se relaciona com o psiquismo. Vejamos:

“A percepção psicológica, que apreende as vivências como estados psíquicos de pessoas empíricas, de sujeitos psicofísicos, entre elas estabelece conexões, sejam elas puramente psíquicas ou psicofísicas, e persegue as leis naturais do devir, do formar-se e transformar-se das vivências psíquicas, esta apercepção psicológica é totalmente outra que a fenomenológica. Nós não dispomos as vivências em nenhuma realidade. Com a realidade, temos nós de lidar apenas enquanto ela é uma realidade visada, representada, intuída, conceptualmente pensada. Relativamente ao problema do tempo, isto quer dizer: interessam-nos as vivências do tempo. Que elas próprias, objetivamente, estejam temporalmente determinadas, que elas se incluam no mundo das coisas e dos sujeitos psíquicos e neste tenham a sua posição, a sua eficiência, o seu ser empírico e a sua gênese, isso não nos move, disso nada sabemos."106

A instauração da consciência fenomenológica é uma solução ao dualismo mente e corpo que dilui a memória como faculdade, mas não esclarece seu processo enquanto fluxo, nem sua função criadora, sequer indicada por uma possível aproximação com a imaginação. Interessa ao autor "esclarecer o a priori do tempo explorando a consciência do tempo, trazer à luz sua constituição essencial e pôr em relevo os eventuais conteúdos de apreensão e caracteres de acto

\footnotetext{
105 Lições para uma Fenomenologia da Consciência Interna do Tempo, p. 40.

${ }^{106}$ Op. cit., p. 42.
} 
especificamente pertencentes ao tempo, aos quais pertencem essencialmente as leis a priori do tempo.”10 7 O “a priori do tempo” citado não é o tempo objetivo, que é uma abstração, mas é definido pela intencionalidade da consciência sobre o tempo, a partir de que todas as relações entre passado, presente e futuro se estabelecem.

O tempo de Husserl é o tempo da linearidade cronológica, em que o vivido se encaminha para o passado como local distante, cada vez mais inacessível à consciência, oposto ao tempo da multiplicidade e do trânsito de planos de Deleuze e Lévy, em que passado e presente fluem permanentemente pela dinâmica de atualizações e virtualizações. O tempo está fixo como uma série infinita bidimensional, de relação assimétrica e transitiva, em que dois tempos não podem existir simultaneamente: é preciso que haja claramente um instante anterior e outro posterior.

Na organização e representação dos tempos, as faculdades cooperam de uma maneira a novamente sugerir a função da memória apenas como retentiva. A percepção inaugura os pontos 0 das vivências no tempo. Mas ela é responsável somente por apreender o 'sentido' e apresentálo à consciência como percepcionado. Conforme Husserl, se trabalhasse isoladamente, a percepção disporia das vivências como uma série de eventos isolados em eterno presente até se apagarem por um esquecimento alienado. É a consciência do tempo e de suas qualidades apriorísticas que permite que se estabeleça o estatuto de reconhecimento do tempo em si, anterior aos eventos que o preenchem, a partir de

${ }^{107}$ Op. cit., p. 43. 
cujas regras se pode apreendêlos como pontos que se movimentam do presente rumo ao passado e em relação de sucessão no sentido contrário.

Nesse processo, a fantasia ocupa um papel fundamental, que muito se relaciona com a memória criadora, ainda que não tenha sido assim desenvolvida pelo autor. É a imaginação que transmuta o 'sentido' e cria novas representações para esse, representạões que exatamente atestam a ação do tempo sobre o vivido. É pela transformação oriunda das operações da fantasia que os fatos passados são definidos enquanto tais, diferentemente dos conteúdos da percepção que estão presentes:

\begin{abstract}
"É, por conseguinte, uma lei universal que, a cada representação dada, se ligue por natureza, uma cadeia contínua de representações, da qual cada uma reproduz o conteúdo da procedente, mas de tal maneira que ela fixe sempre à nova um momento do passado. Assim, a fantasia mostra-se aqui, de um modo peculiar, produtiva. Trata-se aqui do único caso onde ela cria um momento de representagões verdadeiramente novo, a saber, o momento do tempo. Assim, descobrimos no campo da fantasia a origem das representações do tempo."108
\end{abstract}

À conexão intencional entre as imagens dadas no presente e aquelas transformadas pelo tempo, denominou-se, pelo quadro conceitual da fenomenologia, de associação originária. A associação originária é a relação por onde se reconhece não só a ação do tempo, mas a duração dos objetos transcendentais como percepcionados e a própria duração da percepção de tais objetos, cuja tendência é invariavelmente o afastamento da consciência rumo a um passado obscuro, um ponto extremo e distante na linha do tempo:

“Da extensão decorrida, dizemos que está consciente nas retenções e, na verdade, que as partes ou fases não nitidamente delimitáveis da duração, que ficam mais próximas do ponto-

\footnotetext{
${ }^{108}$ Op. cit., p. 46. Lembremos que a imaginação como atividade criadora que plasma as informações sensíveis em novas imagens a serem utilizadas pela mente é uma idéia que vem desde Aristóteles, e está claramente sistematizada desde o Ad Herennium, como vimos na primeira parte de nosso estudo.
} 
agora atual, estão conscientes com uma clareza decrescente; as mais afastadas, as fases do passado que ficam mais para trás, estão conscientes de um modo indefinido (unklar), vazio. E é do mesmo modo depois do decurso da duração total: segundo a sua distância relativamente ao agora atual, tem o que ainda se encontra mais próximo dele, eventualmente, uma pequena clareza, o todo desaparece na obscuridade, numa consciência retencional vazia, e desaparece por fim totalmente (se se pode dizer isto ). Assim que a retenção termina. [...] Ao se mover para o passado, o objeto temporal contrai-se e torna-se com isso, ao mesmo tempo, obscuro."109

Essa noção de passado como algo que contrai as vivências até destruí-las é diametralmente oposta ao cone de Bergson, que utilizamos desde o início dessa parte do estudo para ilustrar a memória como criação. Na memória linear, ou consciência memoriosa fenomenológica, os conteúdos vividos não se acumulam para formar a macro experiência particular do indivíduo. Eles se diluem, são transitórios, "passam" pelo sujeito fenomenológico, entidade cuja construção está alicerçada na atividade da consciência intencional como força imanente, que regula e define as experiências a partir de uma essência apriorística que lhe garante a autenticidade, e por tanto, não permite uma transformação profunda que altere tal essência.

A memória é algo próximo da consciência retencional, a consciência que trabalha sobre as regras apriorísticas específicas do tempo linear, às quais já apresentamos anteriormente. Recordar é deslocar a consciência rumo ao passado, exatamente o oposto da memória de Deleuze e Lévy que se atualiza no presente pelas condições do presente. A associação originária, conceito que poderia aproximar os dois pensamentos modernos tão importantes a respeito da memória, embora sugira a idéia de fluxo e alteração das imagens em função da associação,

${ }^{109}$ Op. cit., p. 59. 
permanece com sua seta apontada somente em um dos sentidos: do passado para o presente, que estabelece relações arbitrárias entre o vivido e o agora.

A memória criadora não é possível sob o jugo da consciência intencional. A consciência memoriosa linear apresentada pela fenomenologia de Husserl não poderia deixar de ser abordada em nossa tese, pois resume uma noção de memória que, acreditamos, ainda é bastante referenciada pelo senso comum: uma ida ao passado pela linha do tempo. O tempo linear dispõe os fatos vividos em movimento de desaparecimento no tempo, especialmente se considerarmos as informações da memória pelos critérios da percepção.

O que pretendemos construir é um conceito de memória distinto que qpera no fluxo vivo das multiplicidades, eque reanima permanentemente o vivido pelas experiências presentes, e cujo comprometimento com as imagens da percepção já está resolvido pela aceitação da própria natureza do processo: a memória é em si cooperada da imaginação, elas não operam sozinhas, e tudo que podemos inferir para nos mantermos mais fiéis às especificidades de seu funcionamento é que podemos falar em graus de mimetismo das imagens memoráveis com a experiência anterior à recordação, mas nunca em uma memória puramente empírica, cuja transfiguração é necessariamente um sinal de equívoco ou esquecimento.

Husserl tem razão quando afirma que algo não pode existir simultaneamente no passado e no presente da mesma forma, a partir de que esboça uma promissora hipótese para utilização e re posicionamento da atividade criadora em seu pensamento. Mas a imposição de uma consciência-sujeito reguladora mina a possibilidade de se avançar sobre a diversidade de atividades da mente expandida, já que todas elas acabam condicionadas às regras da intencionalidade. 
Atualmente, já sabemos que a consciência humana tem sua formação dinâmica, e está em processo até a morte; não é dada por estruturas transcendentais nem inteiramente pela experiência, mas por ambas. O embate entre empirismo e inatismo como apresentado até a modernidade está realmente desgastado. Se o homem nasce como um estrato orgânico organizado de uma forma, e não de outra, é certo que alguns caminhos de aprendizado estão indicados. Mas a cada dia nos surpreendemos com adaptações e usos impensáveis para nossos corpos que criam linhas de fuga para o determinismo organicista de nossas estruturas inatas, e diluem nossos adensamentos orgânicos, psíquicos, físicos, propondo outros territórios visíveis e invisíveis pelos quais podemos nos desdobrar e movimentar entre o que somos, fomos e podemos ser. A memória é o relato dos processos de desterritorialização e re- adensamento de nossa mente expandida. 


\section{PARTE 3 - Depoimento pessoal e memória como recriação do vivido na performance}

"Seria muito difícil construir uma linha clara entre os "personagens" miméticos do drama tradicional e as autênticas "identidades alternadas" da performance autobiográfica. É, provavelmente, mais seguro pensar em um contínuo prolongamento da performanœ de material autobiográfico real rumo às fantasias autobiográficas improvisadas (...)" Marvin Carlson ${ }^{10}$

Chegamos, por fim, aos nossos "estudos de caso" propriamente ditos. Analisaremos alguns processos que contém formas díspares e representativas no que tange à construção do depoimento pessoal no quadro geral das artes performativas para neles melhor observarmos como atuam a forças de atualização responsáveis pela produção de obras esteticamente tão distintas, mas igualmente genuínas quanto à autenticidade do depoimento. Escolhemos quatro ativ idades que consideramos emblemáticas para nosso estudo, pois sua configuração permite estabelecer uma espécie de linha de extremos no que diz respeito ao desejo de expressão mediada pela fábula, ou por sua mais completa supressão.

Se é possível, para efeito de estudo, organizar os processos criativos dessa forma, arriscamos situar a interpretação do ator strictu sensu e a performance autobiográfica como processos pressionados por forças antipódicas de criação. O primeiro tem no centro uma ficção assumida desde sua gênese como tal, criada por um corpo- depoente (o autor) e recriada por outros corpos- depoentes em relação rizomática (o ator e os "espectadores", conforme a teoria teatral nos ensina, fora todos os demais estratos da cena). O último transforma a cena inteira em um

${ }^{110}$ in Performing the Self. 
grande espaço de exposição da memória através da criação de linguagens singulares, que se explicam no fluxo e na lógica interna da própria cenadepoimento que é cada performance. Nessas obras, cada artista relacionado encontrou vetores específicos de trabalho da memória cujos desdobramentos são de grande importância para nosso estudo, como veremos no terceiro capítulo.

A personagem dramática nasce pela confluência inicial de três forças criadoras: o ator, o dramaturgo e o diretor (trata-se do modelo mais simples e tradicional de agenciamento para criação teatral). $\mathrm{O}$ ator tem na personagem préconcebida pelo escritor o suporte por onde irá expor sua memória e elaborar seu depoimento pessoal fabuloso, que, em última instância, é a própria personagem, sua vida interior e exterior, em devir.

As características da personagem direcionam a investigação pessoal do ator para encontrar as referências da memória que mais se adéquam à criação desse outro ser fictício, pelo qual o ator e o autor falam. Tais referências podem aproximá-lo ou afastá lo das representações do cotidiano, mas não têm outra fonte senão a memória criadora do intérprete. Porém, existe uma terceira força criadora, que é o diretor, que problematiza o processo, já que suas determinações quase sempre transformam as estruturas elaboradas inicialmente pelo ator na aproximação com o texto.

Portanto, podemos estabelecer diferentes estágios de construção de depoimento pessoal-personagem dramática. Primeiro, o dramaturgo atualiza determinados virtuais de sua memória criadora (tendo como "ponto de partida" os mais variados estímulos) para descrever e dar voz a outros seres mais ou menos fantásticos e organizar suas ações no texto. 
Na fase seguinte, o ator aproxima- se desse estrato ficcional, que direcionará seu fluxo criativo mnemônico para circunstâncias dramáticas determinadas pelo autor (as circunstâncias dadas de Stansilavski), promovendo uma seleção de materiais que é exatamente a qualificação dos virtuais de memória do ator pressionados pelas condições do texto. O ator "doa" sua memória criadora, e os conteúdos aos quais ela conduz, para animar toda vida interior e exterior de um ser que ganhará corpo somente pela ativação dessa memória. A personagem é como um anteparo, um álibi para que o intérprete possa viver plenamente sua vida recriada. E, por fim (ou conjuntamente), o diretor entra com suas próprias impressões sobre os materiais, que, muitas vezes dizem respeito ao projeto estético "exterior" da cena, e não obedecem às associações entre ator e texto.

Essa seqüência serve apenas como um diagrama básico das principais forças que atuam sobre a formação do depoimento pessoal no processo de criação do ator. Sabemos que o trabalho dramático pode partir de agenciamentos muito mais complexos de estimulação da memória, e que as relações entre os materiais nem sempre seguem um padrão lógico na dinâmica de associação. Uma cor, um jogo, um som, um alimento, podem constituir estratos altamente estimulantes por cujos agenciamentos o intérprete aœessa informações que não estão indicadas no texto, nem nas orientações do diretor, mas que obedecem às intuições pessoais sobre a personagem ligadas ao repertório mais íntimo do ator.

A cena teatral é um grande discurso que combina os materiais de ator, diretor e autor (no mínimo). Nela, a responsabilidade pelo que se apresenta é dividida entre os participantes, e o ator contribui mais diretamente com a disposição do seu depoimento no âmbito da criação da personagem, e da realização 
das ações condizentes com a sua trajetória conforme orientação do diretor. Não queremos dizer, com isso, que ator não interfira na macro-configuração da peça, mas quando nos referimos ao seu depoimento pessoal, sua autonomia de criação geralmente se concentra no meticuloso exercício de composição dos gestos, da voz, da figura e da vida emocional da personagem para, a partir desta, atingir os outros elementos da cena. Esse ponto nos parece de grande importância na caracterização deste depoimento pessoal específico, o depoimento da personagem dramática, com o qual iremos agora compara outros casos.

Antes de chegar ao depoimento na performance, selecionamos um tipo de experiência intermediária que revela como a construção do depoimento pode expandir da criação do papel para a disposição geral da cena. Referimo-nos aos processos criativos dos performers orientados por J erzy Grotowski nas diferentes fases de suas atividades.

O trabalho de Grotowski busca desenvolver um performer que tem na qualidade energética e plástica das ações físicas o caminho para atingir estados espirituais mais elevados, rumo a uma memória que, acreditava ele, ser possivelmente recuperada pela re instauração do ritual teatral. A trajetória artística do diretor passou por diferentes estágios, pelos quais o trabalho sobre a memória mudou radicalmente, como vermos mais detalhadamente no capitulo dois dessa parte. No entanto, podemos afirmar, sem exagero, que o objetivo maior de sua busca foi precisamente atingir a "grande e genuína alma" da humanidade escondida por trás das máscaras individuais cotidianas através do acesso a essa memória coletiva, perdida pelas armadilhas do ego, e que justificava a 
sobrevivência do teatro como ritual laico, e que permite, mais do que qualquer outro ritual, tal instante de revelação.

O depoimento pessoal, agora, exige a autoridade e responsabilidade sobre toda criação, já que os textos e demais enunciadores são orquestrados pelo performer. Internamente, cabe, ainda, a esse artista, buscar os agenciamentos que o auxiliem na pesquisa pelo estado psicofísico que conduz ao desnudamento, à retirada de máscaras e à vivência pura das ações, por meio de cuja exposição o performer atinge o espectador e, juntos, mergulham na memória remota que um dia foi comum a toda nossa raça (e que contém os laços simbólicos e afetivos que nos unem enquanto tal).

Dentro do quadro de referência da performance, os dois tipos de depoimento pessoal apresentados até agora, a personagem dramática e os processos de Grotowski, se enquadram no conjunto de atitudes performativas que Richard Schechner denominou "restored behaviour". "Restored behaviour" (ipsis literis, "comportamento restaurado") tem sido traduzido quase invariavelmente, inclusive por outros pedagogos das artes performativas, como restauração de comportamento. Porém, a tradução literal mesma permite outro sentido que nos parece mais adequado ao pensamento que estamos desenvolvendo: reconstrução de comportamento (pelo trabalho da memória criadora e da produção do depoimento pessoal).

Como veremos, mesmo em trabalhos cujo objetivo seja apresentar, com a máxima fidelidade, a ilusão de uma entidade histórica (a personagem), a memória não age como evocação do passado objetivado em unidades de impressão para realização da criação presente. Trata-se, antes, da atualização de virtuais múltiplos 
pelas forças específicas da criação, nesse caso, forças que buscam o histórico pela ficção. Portanto, o surgimento da personagem, assim como de qualquer tipo de depoimento pessoal, é sempre uma síntese possível que responde ao turbilhão de informações, impressões, emoções em potência (o cone de Bergson), estimuladas pelo presente: o estatuto específico de cada processo criativo.

Nos casos seguintes, escolhemos alguns criadores cuja ação não se vale da personagem como mediadora para disposição dos conteúdos da memória, e denota mais especificamente ao âmbito da performance conforme definido pela teoria formalista. Ou seja, como atividade própria do pós-moderno e cuja identificação se dá, também, pelas características gerais de produção do período: destruição da essência/ personagem, suas competências e do corpo como sujeito; dissolução de fronteiras em todos os níveis de articulação do discurso (e, portanto, do próprio discurso: a descrença e o fim das metanarrativas, marco fundador da atitude pósmoderna, conforme Lyotard em A Condição Pós-moderna), ruptura entre significante e significado e provocação de toda semiótica apriorística, etc'11. Falamos dos performers Marina Abramovic, J oseph Beuys e Spalding Gray.

Abramovic, Beuys e Gray desenvolveram e vem desenvolvendo processos peculiares de construção do depoimento e utilização do corpo depoente em suas criações, em que os relatos da infância e do passado, em geral, surgem como substratos não-mediados para construção da cena. Observaremos a relação de cada performer com seus materiais, os níveis de fábula e supressão em algumas obras importantes de suas trajetórias artísticas, para daí apreendermos as especificidades de cada caso. Nesses processos, a cena funciona inteiramente como um fluxo

\footnotetext{
${ }^{111}$ Ver FÉRAL, Josette. Performance and Teatricality: The Subject Demystified.
} 
memorioso articulado por uma série de enunciadores organizados pelo criador, que geralmente se esvaziam quando reproduzidos em contexto extra-performance, e é forçoso tentar estabelecer procedimentos integralmente comuns de exercício da memória entre todos os artistas.

Como um pequeno apêndice dentro das questões da performance, trataremos do depoimento pessoal que se pretende testemunho direto da experiência: o vídeo-depoimento. O vídeo-depoimento é um tipo de relato que floresceu no pós-guerra que se serve da reprodução mecânica para trazer ao debate as questões acerca da midiatização do testemunho e das implicações éticas que envolvem uma forma de criação que opera ma delicada fronteira da moralidade histórica, dos traumas, dos crimes e das reparações. Esse é um ponto especialmente interessante e, de fato, nevrálgico para nossa discussão, já que o compromisso com a possível "verdade" dos fatos históricos, aqui, adquire dimensões de vida e morte para os artistas depoentes e demais personagens do testemunho.

Pretendemos, assim, ter escolhido, entre tantas distintas manifestações, alguns processos que representam satisfatoriamente a diversidade de construção de depoimentos pessoais que identificamos na atualidade. Verificaremos qualitativamente as frças específicas que atuam sobre cada processo, e como a memória opera seu jogo criativo em resposta a tais conduções. 
Capítulo I - Memória e fabulação no treinamento interpretativo de Stanislavski.

Começaremos analisando a manifestação mais antiga e cujos procedimentos de trabalho estão melhor sistematizados dentre os estudos de caso escolhidos: o trabalho do ator. Tomaremos como referência de método interpretativo o sistema criado e desenvolvido por Konstantin Alexêiev Stanislavski (1863-1938) e seus assessores nos quase quarenta anos de trabalho frente ao Teatro de Arte de Moscou (TAM, fundado por Stanislavski em 1898 com seu colega Vladimir NemiróvitchDantchenko). Também reconhecemos como treinamento interpretativo os demais estudos orientados diretamente pelos princípios técnicos de Stanislavski, mas que se desenvolveram autonomamente mesmo após sua morte (tais como as pesquisas de Eugênio Kusnet no Brasil e de Richard Boleslavski nos Estados Unidos).

O sistema interpretativo permanece como paradigma para o trabalho do ator no teatro dramático, seja para alinhamento ou confronto a respeito da funcionalidade de suas técnicas. No que tange à pesquisa da memória aplicada à criação performática, Stanislavski introduziu à sua época uma pedagogia verdadeiramente transformadora para reconstrução do comportamento histórico que redefiniu o status e os atributos do ator, e que é melhor compreendida se resgatadas as circunstâncias artísticas que envolveram sua criação.

Voltemos, então, aos primórdios do aprendizado de Stanislavski, cuja conjuntura revelava o completo desgaste da tradição do ator intuitivo. Às suas palavras na biografia Minha Vida na Arte: 
final de um trabalho - mas silenciavam quanto ao modo de alcançar tais resultados, quanto ao método criativo a ser usado a fim de aproximar-se da meta desejada [...] Não havia regras básicas nem sistematização. Os expedientes práticos não eram verificados pela pesquisa científica. Eu me sentia como uma espécie de massa com a qual estavam cozendo papéis de um gosto e aspecto definidos".

Sua crítica antecipava a crescente insatisfação do público que levaria o teatro russo (e também europeu) à crise do final do século XIX. Stanislavski percebeu que toda uma "escola" estava ruindo diante da falta de procedimentos de trabalho que tirassem o artista de jugo de seu carisma (ou da falta dele) e de seus atrativos pessoais que caracterizavam as atuações do melodrama e dos vaudevilles.

O teatro revela os agenciamentos hegemônicos de seu tempo. Estamos tratando de um período (metade final do século XVIII) em que a arte do ator se desenvolvia fundamentalmente nos Teatros Imperiais. Ainda que a produção dos teatros provinciais (administrados pelos poderes públicos locais), particulares (geralmente mantidos pela alta aristocracia rural, que seguia a mesma lógica de gerenciamento da aristocracia urbana) ou de grupos amadores não pudesse mais ser ignorada, o grande volume de fomento estava invariavelmente concentrado na subvenção oferecida pela nobreza. Destinavar se às atividades desenvolvidas em seus órgãos culturais: os Teatros Imperiais de Moscou e São Petersburgo, o Teatro da Corte do Hermitage e as salas sustentadas diretamente por algum nobremecenas em particular.

Visando a apresentação de textos que melhor divertissem e entretivessem os nobres, as montagens recorriam quase sempre a autores franceses especialistas tanto nos vaudevilles e em todo tipo de comédia de situação, como nos 
melodramas. Tais gêneros se baseiam em "tipos", para os quais a mobilidade de representação é consideravelmente circunscrita.

As mnemo-técnicas eram precárias, muito inferiores àquelas utilizadas pela Oratória e Retórica antigas. Pois, se para os poetas (e, de fato, para todo cidadão antigo) era fundamental a memorização dos conteúdos de cada parte do discurso (ver o place-system apresentado no primeiro capítulo), e dos próprios relatos pessoais de toda natureza para afirmação das identidades pessoais, coletivas ou artísticas, em tais gêneros modernos a disposição dos recursos buscava o impacto emocional sobre o público, independentemente das palavras.

Os atores costumavam receber suas falas poucas horas antes de entrar em cena, já que eram especializados no papel, e o ponto era recurso muito utilizado. Por isso a idéia de "sucesso" ou "fracasso" de uma performance estarem tão condicionados aos talentos pessoais do ator muito mais do que a sua capacidade de transformação. Pensando o trabalho de tais artistas à luz do conceito de performatividade, o "sucesso" ou "fracasso" ("felicitous" ou "infelicitous", como nos apresenta John Austin ${ }^{112}$ ) de sua atividade diz respeito muito mais ao âmbito da efetividade da ação performativa do que à primeira instância emblemática de uma ação de tal natureza: a elaboração da declaração, em uma cisão que beira a cabotinagem.

Ao fim do século XIX e início do século XX, a conjuntura político-econômica russa passa por modificações que redefinem o diagrama entre poder público e produção artística e permitem o surgimento de nov as experiências, $\mathrm{O}$ teatro passa a receber o apoio mais interessado dos administradores provinciais, funcionários

\footnotetext{
${ }^{112}$ Ver sub-capítulo Speech Act Theory, em Performance a critical introduction, p. 61.
} 
públicos e da nobreza "intermediária", uma classe média nacionalista que cresce e se fortaleœ rapidamente, identificada com obras que tratem de temáticas nacionais. O apreço por conteúdos dessa natureza produziu um público mais permanente para escritores que se dispusessem a seguir a tradição russa de crítica e sátira de costumes e figuras sociais, e concretizassem a transição para uma literatura livre das transfusões neoclássicas européias.

Dois nomes se destacam nessa transição para uma literatura dramática genuinamente nacional: Vladislav Alexândrovitch Ózerov (1770-1816) e Ivan Krilov (1768-1844). Foi através de um olhar "simples" e mais sóbrio sobre a sociedade que Krilov introduziu um estilo de contar histórias que influenciaria o movimento que conheceríamos mais tarde como Realismo na literatura russa, de cujo diálogo com Stanislavski fez nascer a pedagogia interpretativa.

Entre os dramaturgos que beberam da fonte realista de Krilov, destacam-se Aleksandr Pissarev (1803-1828), Vassili Kapnist (1795-1829), Nikolai Khmelnítzki (1789-1840) e, em especial, Aleksander Griboiêdov (1795-1840). A produção de Griboiêdov delimita o início de um novo momento na história da dramaturgia russa sob muitos aspectos. Com suas obras, o realismo extravasa definitivamente o campo da Literatura para influenciar diretamente a criação do ator. Suas personagens são defendidas por grandes atores de várias gerações russas, como Aleksândr Lênski, Vassili Karatínguin, Mikhail Schchépkin e, posteriormente, Konstantin Stanislavski e Vassíli Katchálov. Às palavras do professor Jacó Guinsbourg:

"Tchátzki (personagem de sua obra mais popular A Desgraça de ter Espírito), a jovem inteligência brilhante (que talvez afirme demasiado esta qualidade), é o protótipo do intelectual russo cujos talentos e desprendimento idealista são desperdiçados sem empenho objetivo, 
inaugurando a série dos "homens supérfluos" , que receberá nas transcrições de Turgêniev, Gontchárov no seu famoso Oblomov, Tchekov, entre outros, personificações sócio-psicológicas marcantes na literatura romanesca e teatral da Rússia”.113

Paralelamente ao desenvolvimento da dramaturgia realista, o aumento da classe média urbana ${ }^{114}$ produziu um fenômeno que tornou a cena teatral russa bastante paradoxal com a popularização ainda mais acentuada dos vaudevilles e do melodrama francês. Sob esse embate de gêneros, ergueram- se as duas correntes de tratamento da atuação no final do século XIX, e que terminariam com a hegemonia do realismo no século XX pelas pesquisas do Teatro de Arte de Moscou. De um lado estavam os remanescentes de tradição melodramática, de outro (ou em resposta a), estavam os atores 115 de linhagem mais realista, cuja técnica incipiente ainda não compreendia os mecanismos necessários para se atingir a reconstrução de comportamento no nível desejado.

Do Teatro Máli veio o principal nome da atuação realista pré-Stanislavski. Mikhail Schchépkin implantou no teatro uma série de práticas para eliminar a herança melodramática no trabalho do ator e permitir a composição mais próxima da figura humana natural: limpeza de gestos e controle racional da voz, que resultava em uma interpretação tranqüila e transparente (especialmente quando comparada às explosivas figuras melodramáticas). Não tardou para que o estilo Schchépkin passasse a se confundir com a própria "figura típica do cidadão russo", e, seus trabalhos, a serem considerados pelo público como a encarnação da "alma

\footnotetext{
113 Stanislávski, Méierhold \& Cia.p. 277.

${ }^{114}$ Algumas alterações ocorridas na conjuntura sócio-política russa na segunda metade do século XIX repercutiram fortemente na formação de publico dos teatros, que se diversificou significativamente. Talvez a mais importante tenha sido a abolição da servidão no campo, instituída por Alexandre II, que provocou intenso êxodo rural para as grandes e médias cidades.

${ }^{115}$ É impossível não resgatar o sublime material de estímulo para a criação do ator realista encontrado nas obras de Nikolai Gogol (1809-1852), especialmente em seu Revizor (O Inspetor Geral, peça de 1836).
} 
russa”. Seu estilo exerceu grande influência em Stanislavski nos primeiros anos. Entretanto, até aqui, ainda não podemos falar em uma reflexão pedagógica formal, na formação de um corpo metodológico que ultrapassasse a experiência da cena específica e induzisse técnicas úteis ao ator realista em geral.

A evolução do realismo, em permanente tensão com o melodrama, é a tônica que orienta e justifica a criação do método interpretativo de Stanislavski conforme o apresentaremos, e será sempre nesse diálogo com a dramaturgia que se construirão as bases de seu sistema.

Em 1897, Stanislavski, então um ator amador, mas já com 34 anos e certa experiência em vaudevilles e operetas conhece Vladimir Nemiróvitch-Dantchenko. Esse encontro marcaria o início de uma colaboração que resultaria na criação, um ano depois, do mais importante centro de investigações sobre o ator no ocidente do século passado.

O TAM nasce com a perspectiva de que a renovação do teatro moderno se daria pela criação de um novo ator. O intérprete está no centro da criação, e para que exista um novo teatro alinhado com o seu tempo, é necessário criar técnicas de formação de um ator que exprimam o homem de seu tempo. É evidente que a solução para esse impasse não se daria nas escolas dos Teatros Imperiais, as únicas com estrutura humana e material condizente para realizar tal tarefa. Se foi pelo conservadorismo dos Teatros Imperiais que se sufocou a pesquisa de novas técnicas e se congelou os repertórios para adequá-los ao gosto da nobreza, somente um teatro escola de cunho radicalmente investigativo poderia se lançar em tal empreitada. 
A orientação pedagógica do TAM já nasce comprometida com o realismo de forte teor psicológico. Eis porque nosso esforço em re-contextualizar os eventos históricos e artísticos anteriores à formação do TAM. O repúdio às convenções defendido por Stanislavski representava um posicionamento não contra a teatralidade da cena, mas contra uma "teatralidade" que na época era sinônimo de clicheria, de um código gestual desgastado e fixado no efeito emocional sobre o espectador. Paradoxalmente, hoje, a cena realista carrega o estigma da teatralidade quase como um fardo, uma espécie de dichê canônico da modernidade no quadro pós-moderno das artes performativas.

Os primeiros anos de atividade não trouxeram revelações muito contundentes sobre possíveis direcionamentos de trabalho. As personagens eram quase que "implantadas" já praticamente prontas nos alunos, e traziam consigo muitas das velhas e indesejáveis convenções. É quando toma parte das atividades do TAM o médico e escritor Anton Pavlovitch Tchekov que as pesquisas ganham fôlego e identidade. Desœendente da tradição de Gógol e Turguêniev, Tchekov reteve dos seus antecessores tanto o talento satírico e a percepção aguçada dos tipos e relações sociais da época, como a habilidade para integrar-se à dinâmica de criação de atores e diretores.

Alimentadas pela dramaturgia de Tchekov, as investigações do TAM se desenvolveram enormemente no sentido de desvendar as implicações na construção da verdade cênica. A verdade como reflexo da essência atravessou o iluminismo, o romantismo e chegou com força nas primeiras décadas da modernidade, e está na base da noção da performance como comunhão. A verdade/ essência se apresenta, geralmente, como o domínio do humano por trás 
das individualidades, o que unifica a experiência e remete ora aos conscientes e imaginários coletivos, ora a questões comuns da humanidade, ora ainda às catarses que a exposição de um sujeito pode promover por seus atos performativos. Aqui, ela surge amparada pela psicanálise emergente, reflexologia e pela psicologia experimental do início do século para orientar um projeto de ator que alinhasse a construção artificial com a vida natural pelo entendimento e reprodução dos processos psico-físicos que determinam seu funcionamento à luz das teorias citadas.

As personagens tchekovianas têm uma vida interior de fato muito mais complexa em termos de construção psicológica como estímulo para o ator. Tais figuras não poderiam ser incorporadas com os recursos convencionais de então, porque demandavam a representação de estados psíquicas delicados, nuances sutis que exigiam do ator um estudo prévio do comportamento humano cotidiano, e do seu próprio, em especial, para poder recriá- las ${ }^{116}$.

Inicialmente, os exercícios consistiam, basicamente, em tentativas de desconstrução do corpo "convencional” através do relaxamento físico (externo) e da imobilidade, a fim de se exercitar somente a atividade interior do aluno. Esse princípio conduziria a etapa inicial de suas investigações: a supressão do movimento inexpressivo e a observação dos processos internos que conduzem à verdade da cena. O corpo é o ponto de observação: suas tensões físicas são a imagem corporal das tensões psíquicas que deformam o ator interna e

\footnotetext{
${ }^{116}$ Há de se perguntar se já não existe, desde o começo das pesquisas de Stanislavski, uma busca pelo "desnudamento" e pela "auto-revelação" do ator tão almejada e defendida por Grotowski meio século mais tarde, e em que termos. Retomaremos essa discussão à frente.
} 
externamente em certos padrões, e precisam ser suavizados antes de se construir os novos padrões fictícios de comportamento que caracterizam a personagem:

“- O objetivo de nossa arte não só criar 'a vida do espírito humano' mas também transmiti-lo externamente de forma artística - corrigiu Tórtsov -. Por isso o ator não deve somente viver internamente o papel, senão também encarnar o que tenha experimentado. Observe que a dependência da atuação externa em relação à vivência é particularmente íntima em nossa orientação artística. Para refletir uma mais delicada e completa vida subconsciente, tem que contar com um aparato corpóreo e vocal excepcio nalmente sensível e preparada à perfeição. A voz e o corpo devem expressar do modo mais útil, direta e instantaneamente, os sentimentos internos mais delicados, quase inacessíveis."117

Com os resultados positivos das primeiras experiências, Stanislavski (que passou a contar com a valiosa colaboração de ex-alunos como Leopold Sulerjítzki) percebeu quais faculdades da mente humana estão mais diretamente envolvidas na criação do ator e, portanto, mereceriam a formulação de estímulos específicos, entre as quais destacam-se imediatamente a memória e a imaginação. Lembremos o quanto seria forçoso exigir de Stanislavski um pensamento não arborescente sobre o bio- funcionamento afetivo num período em que a psicanálise e a psicologia experimental (em especial as obras de Théodule Armand Ribot Les Maladies de la Volonté, Psychologie de l'attentione, principalmente, Les maladies de la memoire, que influenciou reconhecidamente Stanisalvski) apareciam como as disciplinas mais "abertas" a compreender os comportamentos humanos para além das questões morais; e a medicina ainda determinava rigorosamente o âmbito das patologias mentais.

\footnotetext{
${ }^{117}$ El Trabajo de Actor sobre si mismo - el trabajo sobre si mismo em el proceso creador de las vivencias. I DILETANTISMO. p. 63. Traduções minhas para todas as citações.
} 
O estudo da memória começava a preparar o campo de investigação que encontraria mais tarde em Bergson e Foucault sua expressão mais radical. Portanto, a questão fundamental, ainda aqui, consistia em desvendar os canais de acesso aos conteúdos vivenciados que permitissem sua apresentação e transformação a fim de se reconstruir um comportamento igual ao comportamento da personagem.

Nesse processo, a memória e a imaginação estão na base do sistema. As técnicas se orientam no sentido de criar um acervo de experiências emocionais e de encontrar os operadores que permitam uma fabulação tão eficiente para o ator que ele consiga se projetar inteiramente nas situações da personagem. Essa etapa das pesquisas foi denominada Linha das Forças Motivas. Analisemos as diretrizes técnicas que a compõem

O primeiro princípio, como já foi adiantado, se refere ao relaxamento muscular. Stanislavski observou que um corpo excessivamente contraído carrega uma expressividade que nem sempre está adequada à realidade emocional da personagem. Não é um corpo disponível para a manifestação transparente das respostas emocionais, pois os núcleos de tensão bloqueiam as ações naturais que vem como resposta aos diferentes estados internos. Em suma, é um corpo que já carrega uma "tensão expressiva" de grande teor informativo, e que impede a expressão das oscilações mais sutis no diagrama dramático das personagens.

Tais tensões são registros de memórias musculares, rastros de traumas físicos ou psíquicos que se concentram em determinadas regiões mais sensíveis ou expostas à sobrecarga de "informação" (ou de esforço, que promove as hipertensões musculares). Na perspectiva acertada de Stanislavski, esse excesso de 
tensão é também um excesso de informação armazenado sob a forma de memória muscular.

Para aprimorar o controle das tensões, eram indicados não somente exercícios de alongamento realizados em aula, mas o desenvolvimento do denominado mecanismo controlador. O controlador nada mais é do que a vigilância constante e consciente em todas as situações cotidianas sobre o aparecimento de novas tensões e a capacidade de induzir voluntariamente a descontração dos músculos atacados. Essa prática envolve um treino sutil e perene e deve acompanhar o ator por toda vida, pois somente o treino em aula não é suficiente para descondicionar um corpo que acumula tantas tensões excessivas ao longo do dia.

Já em sua primeira etapa das investigações, tantas vezes acusada de promover exclusivamente a instrumentalização dos processos internos do ator, Stanislavski parte do corpo para criação dos exercícios e pensa o âmbito físico do homem como reflexo da memória e de sua vida psíquica. Sua abordagem, aparentemente psicologizante, foi a primeira a pensar sistematicamente no teatro as relações e formações dos corpos pela influência do vivido que permanece, e o levou a estudar, antes da reconstrução de comportamento que cria a personagem, os processos psico-físicos do comportamento cotidiano e seus possíveis descondicionantes, tomando o ator como cobaia para uma pesquisa que é em si, trans-teatral.

O conceito seguinte diz respeito à atenção na cena. A concentração de atenção é a capacidade do ator de focalizar sua atenção e empenho para um único objetivo: atingir e vivenciar o sentimento da personagem. Em adequado estado de 
concentração, o intérprete consegue encontrar a medida emocional que cada situação ficcional solicita, e se insere naturalmente nesse contexto fabuloso sem precisar forjar expressões.

A concentração não é um estado passivo, que isola o atuador do ambiente criando um mundo de delírio particular. É precisamente o contrário. Ela se dá pela concentração do ator não na busca metafísica do estado, mas pela realização prática das pequenas e grandes ações que a personagem deve cumprir em cena. Voltando sua atenção para os objetos de trabalho, o ator naturalmente se esquece do público e abandona qualquer impulso de representar para ele, forjando expressões excessivas: “o segredo parece ser bastante simples: para se esquecer da platéia, tem que se interessar pelo que existe na cena.."118

O resultado de seu aprimoramento é a capacidade de preservar o estado mesmo nas situações externas mais dispersivas. Em outras palavras, a concentração consiste em conseguir sustentar o direcionamento do fluxo da performance para as circunstâncias dramáticas com o mínimo de esforço possível.

Os círculos de atenção compõem uma técnica complementar à concentração e servem para facilitá-la. Eles abrangem as áreas de interação do ator com o ambiente e podem ser pequenos, médios ou grandes conforme a proximidade do intérprete em relação aos objetos que os compõem. Eles exercitam, em um primeiro momento, a percepção do todo da cena, mas com a finalidade de situar o ator em seu universo fictício particular, para que ele consiga erguer em torno de si a quarta parede e experimente a solidão em público: ser observado sem sofrer influência da audiência ou de outros incidentes (nesse sentido, as técnicas dos

118 Op. Cit., p. 124. 
círculos de atenção e da solidão em público se opõem diametralmente àquelas de jogo experimentadas nas linguagens farsescas e melodramáticas).

A quarta parede é um recurso de delimitação de fluxo típica do teatro ilusionista, que se baseia na convenção de que o público está assistindo a uma performance que acontece diante dele, e não para ele, portanto, não requer (e, de fato, não deseja) a participação direta da audiência. Ela trabalha para acentuar a relação de exposição psico-física do intérprete como suporte do discurso, que enuncia seu depoimento memorioso e fabuloso em nome de um terceiro (a personagem, que fala pelo autor) em um jogo de distanciamentos que paradoxalmente busca a recriação de uma cena o mais próxima possível da realidade cotidiana.

Para seguirmos na descrição da primeira etapa do sistema de Stanislavski, convém que expliquemos quais são as Forças Motivas que dão nome ao processo. São três: o sentimento, a mente e a vontade. No método, o sentimento é o maior dos mestres, porém reside numa esfera do aparelho psíquico que não está sujeita à evocação e utilização imediata dos materiais para fins expressivos. Portanto, ele deve ser "despertado" pelas duas outras forças motivadoras: a mente (concebida aqui como intelecto, faculdade da razão) e a vontade. Em seu método, Stanislavski pretendeu sempre atingir indiretamente os sentimentos/emoções, para evitar clichês de expressão. O caminho é mental no sentido de revelar ao ator a lógica de conduta da personagem e levantar as emoções provavelmente envolvidas em seus movimentos pra daí, indiretamente, conduzir o ator à incorporação desse comportamento: "dessa forma, as lembranças do que se tenha vivido surgem 
refletidas sobre a base de relação indissolúvel entre o físico e o psíquico no processo de criação."119

Trataremos, a partir de agora, dos operadores do sistema que solicitam diretamente o trabalho sobre as memórias por parte do ator, e que estão comprometidos mais profundamente com a dinâmica de fabulação necessária para promover o alinhamento comportamental com as personagens: a memória emotiva e a memória das sensações.

A memória das emoções é um conceito que Stanislavski desenvolve a partir da idéia de "memória afetiva" de $\operatorname{Ribot}^{120}$, porém buscando para efeito de investigação teatral uma aproximação entre a ação e a lembrança que não existe a princípio na teoria experimental. Stanisalvski conecta intimamente o trabalho da memória das emoções àquele da memória das sensações e a uma possível “memória motriz', que já era intuída desde o início das pesquisas, mas que só foi verdadeiramente identificada e incorporada no Método das Ações Físicas. A memória das emoções é a capacidade de todo ser humano de concentrar e apresentar registros afetivos ligados a determinadas situações, situações que estabelecem conexões absolutamente singulares com as emoções, e cuja singularidade define o universo mnemo-afetivo do ator.

Tais emoções nascem antes de uma memória das sensações, da vivência do que é apreendido pelos sentidos e reconhecido em padrões de percepção para daí se desdobrar em referenciais emocionais. Stanislavski insiste nessa questão: a

\footnotetext{
${ }^{119}$ Comentários de Salomon Merener, in op. cit., p. 233.

120 "Partindo das conclusões de Ribot sobre a presença de uma memória afetiva do homem, Stanislavski investigou o papel desta na criação artística. Desenvolveu e aprofundou as conclusões teóricas e substituiu seu termo "memória afetiva" pelo conceito mais completo e exato "memória das emoções". Comentários de Salomón Merener, in op. cit., p. 222.
} 
memória das sensações é autônoma, pode tanto se encerar na evocação da sensação quanto provocar a memória das emoções, e sugere que é mais comum a atualização da memória das emoções pela pressão das sensações (ou de suas memórias) do que por movimentos abstratos da mente:

\begin{abstract}
"Precisamente essa memória que te ajuda a repetir todas as sensações conhecidas, vividas anteriormente, aquelas que experimentou durante os passeios a Moskvin, e com a morte de seu amigo, é a memória emotiva. Assim como sua memória visual faz reviver diante da sua visão interior um objeto esquecido há muit0 tempo, um lugar ou uma pessoa, a memória emotiva pode fazer reviver emoções experimentadas. Parecia que elas haviam se apagado de todo, mas, de repente, alguma sugestão, uma idéia ou uma figura conhecida faz com que as emoções te dominem, às vezes, com mais força do que nunca, outras, mais debilmente; em outras ocasiões, são iguais às da primeira vez, e em outras, têm um aspecto diferente. .121
\end{abstract}

E sobre uma hierarquia dos sentidos:

"Não obstante, às vezes falarei dos cinco sentidos paralelamente à memória emotiva. Resulta mais conveniente. É necessário, e como isso faz muito falta ao artista quando está atuando, a lembrança das sensações dos sentidos? Para responder, tomemos cada uma elas separadamente. De nossos sentidos, a visão é o que capta mais diretamente as impressões. Também a audição é extremamente sensível. Por isso, é mais fácil trabalhar nossa sensibilidade através do olho e do ouvido. ${ }^{122}$

Notamos que a memória das emoções remete tanto à idéia de um acervo técnico quanto de um processo cujas demandas estão diretamente relacionadas com o presente. Stanislavski aponta a relação sensorial como base para evocação, cujos materiais são o ponto de partida para o trabalho da imaginação.

\footnotetext{
${ }^{121}$ Op. Cit., p. 224.

122 Op. cit., 225.
} 
Duas são as ferramentas imaginativas complementares para auxiliar o intérprete a afinar a sensibilidade e a disponibilidade em compreender e criar a lógica de funcionamento da personagem: o "se" mágico e as circunstâncias dadas.

O “se mágico" é o mecanismo de estimulação da imaginação e memória criadora que induz o ator a se inserir em uma existência ficcional (muitas vezes, bastante distinta da sua). Conforme explica Stanislavski: “Deve-se perguntar: 'se tudo isso fosse real, de que forma eu reagiria? O que eu faria? [...] E, então, normal e naturalmente [...] este se funciona como uma alavanca que lhe permite alcançar um mundo de criatividade"123. Se o estímulo se completa satisfatoriamente, o ator consegue estabelecer uma cadeia de associações que o situam verdadeiramente na situação fantástica, ou imaginar conexões afetivas análogas que a preencham, e, assim, criar uma rede de referências emocionais semelhante à fábula que é vivida com a mesma potência como se fôsse real.

Por isso Stanislavski ressalta permanentemente a qualidade de observador de um bom ator. Um intérprete deve estar sempre atento não somente às figuras humanas que o cercam, a suas relações e comportamentos (embora essas sejam as fontes mais diretas de material para suas composições), mas à toda diversidade de seres que habitam as paisagens, às cores, aos cheiros, à musicalidade dos diversos sotaques, às formas das plantas. Todas essas imagens sensoriais formam o material de trabalho para a memória e a imaginação, e é a diversidade de registros mnemônicos que define a qualidade da criação do ator nesse sistema: a qualidade de sua memória emotiva .

${ }^{123}$ Manual do Ator, pp. 125-126. 
Nem sempre um sentimento é aœssado imediatamente ou pela simples leitura do texto. Stanislavski defende que esse é o mais intangível dos mestres. Por isso são necessários exercícios específicos que, através das forças da mente e da vontade, permitam transformar informações do repertório pessoal que aproximem o ator da situação fabulosa. (pode ser um cheiro, uma cor, um som, não necessariamente uma palavra). Como foi dito anteriormente, não existem regras que conectem a situação dramática com as emoções, por isso, os materiais de estimulação podem ser diversos.

Da mesma forma, a imaginação funciona como o grande motor para completar as lacunas mais ou menos claras da memória, aproximando as duas faculdades em um nível que, como já vimos, não pode ser distinguido e medido quando o processo criativo se inicia. Um ator que tem a observação, a memória e a imaginação pouco desenvolvidas não consegue nem criar nem apreender conscientemente o repertório. Para esse ator, o trabalho com o "se mágico" é mais difícil, pois não se tem controle sobre os materiais armazenados.

As circunstâncias dadas remetem ao enredo da peça, e englobam todas as informações sobre a trajetória da personagem na trama (aspectos espaciais, históricos, tipo de relação que se estabelece com as demais personagens, etc.). Comporta também a situações "externas" ao pequeno círculo de atenção do ator: encenação, direção, cenário, sonoplastia, figurinos, adereço e objetos de cena. Em suma, é o conjunto completo de circunstâncias vivenciadas pelo ator para realizar o trabalho interpretativo.

Esse operador delimita ainda mais o caminho da fabulação para o ator. As informações que compõe as circunstâncias dadas formam o mapa em que a 
memória e a imaginação do intérprete serão estimuladas: a personagem " $\mathrm{x}$ " vive na época " $\mathrm{y}$ ", veste- se com tais roupas, odeia ou ama tais outras personagens por esse ou aquele motivo e utiliza esses ou aqueles objetos para tais finalidades. Se o "se mágico" permite a transposição orgânica do ator para determinado contexto, as circunstâncias dadas definem detalhadamente esse contexto.

Nesse sentido, é fundamental avaliar a participação de Tchekov na organização do sistema. Foi crucial a contribuição do dramaturgo para o êxito dos exercícios do "se mágico" e das circunstâncias dadas, já que vem do texto o conteúdo ficcional que permitirá ao ator conhecer os elementos da nova realidade em que deverá "se inserir". Dentro do método, somente uma dramaturgia que explorasse com profundidade os sentimentos humanos, suas contradições e embates, poderia estimular a produção de técnicas complexas de interpretação.

Entretanto, de nada adiantará utilizar tais técnicas e ter um vasto repertório de imagens e de emoções dilatadas se os exercícios não resultarem em um sentimento de verdade e em uma fé cênica para o ator a respeito da vida da personagem. Esse mergulho orgânico na alma humana, por meio das ferramentas citadas, deveria ser tão profundo que, acreditava Stanislavski, por si só motivaria o ator a incorporar o papel independente de suportes externos. Assim, uma faca assassina poderia ser de papelão, castelos podem ser apenas cavaletes e escadas se tornam muralhas aos olhos de um ator com a fé cênica necessária. A utopia da cena humanista/ naturalista concretizaria a grande comunhão entre homens do palco e da platéia e restituiria a função maior da arte teatral que foi destruída pelos teatros “cabotinos” ao longo do século XIX. 
O sistema de Stanislavski já reconhecia, desde sua gênese, que uma construção "humanizada" da personagem precisa acontecer em etapas que permitam identificar seus graus de individuação, e não como um bloco monotípico. O despertar dos processos internos é apenas o início da estruturação do material expressivo, cujo tratamento mais requintado será dado pela segmentação das unidades e pelo esclarecimento dos objetivos da personagem.

A prática para determinar as unidades consiste em recortar os momentos dramáticos em cada cena a fim de analisar mais atentamente as sutilezas das micro-situações (as unidades em si). A intenção é recortar os instantes dramáticos da personagem, romper para fim de estudo a linha contínua que define sua existência como entidade viva para se observar os detalhes que explicam seu comportamento em cada etapa da narrativa, e, assim, compreender melhor o movimento de sua trajetória. Acima de tudo, é pelas unidades que se pode reconhecer a memória da personagem.

A análise das unidades permite ao intérprete encontrar os objetivos que amparam suas ações e justificam sua presença em cena. Cada unidade tem seus objetivos menores, que relacionam os instantes específicos na vida da personagem. Mas a concatenação psicológica dos objetivos menores conduz a uma linha de comportamento maior que existe até na mais medíocre das figuras dramáticas: o superobjetivo. Embora não constitua exatamente uma técnica de treinamento, o princípio do superobjetivo resume a coerência interna da personagem, e orienta toda a linha direta de ação. Em poucas palavras, concentra a essência final de construção da personagem a que toda a linha da forças motivas se propõe. 
Completando os elementos constitutivos da vida interior estão a comunhão (estado de conexão e comunicação sensorial/verbal do ator consigo mesmo e com o ambiente) a adaptação (os mecanismos internos e extemos de que os atores se valem para adequarem-se às relações pessoais e com os objetos na cena) e a imaginação, o mais fundamental de todos os requisitos para se trabalhar o método.

Os elementos constitutivos da vida interior formam o quadro técnico pelo qual Stanislavski estruturou a primeira fase de seu treinamento interpretativo. Esse período é marcado até a morte de Tchekov, que redirecionou profundamente o andamento da pesquisas do TAM.

Em 1918, Stanislavski desenvolve um projeto que seria de grande contribuição para a consolidação da etapa seguinte de suas pesquisas Trata-se do Estúdio de Ópera do Bolshoi. O trabalho de interpretação com os cantores, a partir da estrutura rítmica das partituras musicais, despertou para a importância do ritmo interno na criação da personagem, e produziu oconceito de ação rítmica.

Stanislavski reconheceu, no avanço de suas investigações, que uma limitação fundamental encontrada em seu sistema consistia na fixação e recuperação dos materiais expressivos. Por mais eficiente que fossem os exercícios, a manifestação de um estado interno muitas vezes encontrava formas irrepetíveis no corpo, o que se tornava um problema para trabalho do ator que precisa apresentar a mesma performance inúmeras vezes durante uma temporada. Por tanto, o eixo de abordagem precisaria se deslocar para o material que pode ser codificado: a ação física, e não mais os estados internos.

Evidentemente, o approach sobre a criação das ações físicas seguiria os preceitos já desenvolvidos pelos estudos até então, ou seja, toda ação física é 
coerente ao comportamento psicológico: uma ação psico-física alinhada à lógica interna de funcionamento da personagem. Portanto, esse redirecionamento da pesquisas não significa de modo algum uma ruptura com a fase anterior. Ele é um passo adiante na sistematização dos procedimentos que pressupõe um domínio avançado dos exercícios da Linha das Forças Motivas, base de toda a atitude viva do ator.

Essa fase ulterior ficou conhecida como Método das Ações Físicas, e foi interrompida com a morte do pesquisador. Os exercícios visavam a direcionar a concentração do ator sobre o como fazer, sobre a qualidade e o ritmo na realização das ações. Observou-se que a repetição de uma mesma ação, com intensidades diferentes, altera não somente as referências pessoais acessadas da memória emotiva pelo "se mágico", como pode sugerir novas configurações para todos demais elementos da vida interior.

Tal constatação é muito importante, pois revela que a execução aparentemente mecânica de um movimento quando realizada com consciência e concentração, pode esgatar as circunstâncias dadas e restaurar o seu sentido, e que não somente os processos internos conduzem à ação. Em termos estritamente científicos, as pesquisas de Stanislavski anteciparam a idéia de um fluxo de memória em que a vias aferentes e eferentes tem a mesma importância, ou seja, o aparato motor e sensorial é tão determinante no processo de criação das memórias quanto o centro nervoso, pois desse primeiro vêm os estímulos que desencadeiam as associações de registros do cérebro. E essas associações não seguem necessariamente uma ordem b́gica de solicitação-resposta, antes pelo contránio. Entretanto, compreendemos que não existia uma neurologia suficientemente 
desenvolvida e direcionada para o esclarecimento dessas relações no início do século passado.

Nos últimos anos de suas atividades, as ações físicas adquiriram considerável autonomia em relação ao texto escrito, se comparado às pesquisas dos primeiros anos. Em sua montagem inacabada de O Tartufo (interrompida pelo seu falecimento), Stanislavski trabalhou as partituras físicas praticamente sem o texto, partindo apenas da idéia geral de cada ator sobre o conteúdo e o desenvolvimento da cena.

Primeiro, se apresentava o esquema de ações, para depois entrar o texto, um processo inverso àquele experimentado na etapa da Linha das Forças Motivas. O quadro de conceitos foi modificado por uma perspectiva mais processual, em que se fundem as forças motivas vontade- sentimento em um vetor dinâmico de criação, orientado pela atividade mental. $\mathrm{O}$ entendimento de organicidade se encaminha mais para a resolução da ação psicofísica do que para o macro-conjunto de implicações que alimentam os processos interiores.

Talvez seja necessário que se dê alguma atenção à noção de organicidade. Para Stanislavski tratavase de encontrar uma pedagogia para a reconstrução em cena da condição humana mais simples e natural, que conforme o diretor, escapa ao ator no instante em que se convenciona a entrada em cena. Seguindo essa concepção, o corpo-mente orgâniø desenvolve-se quando o corpo responde a todas as exigências feitas pela mente de uma maneira que nãoé nem redundante, nem negligente, nem incoerente. Para Stanislavski, a organicidade no palco não era análoga, mas igual à organicidade na vida; e poderia ser construída pelo 
alinhamento, este sim, construído por analogias, entre o comportamento cênico e o comportamento natural.

O treinamento interpretativo traz à berlinda algumas das questões fundamentais sobre utilização da memória criadora e construção do depoimento pessoal no campo da performance. De fato, a interpretação acabou se afirmando na teoria da performance contemporânea, como a raiz comportamental da performance moderna, pela qual se aglutinam e se revelam as características essenciais do que hoje chamamos de teatralidade, e que, pela crítica formalista, se oporia ao estatuto da performance como arte do pós- moderno:

\begin{abstract}
"Teatralidade é algo que ela (Féral) vê como devotado à representação, à narração, ao fechamento e à construção de sujeitos em um espaço físico e psicológico, o reino das estruturas codificadas, ou o que Kristeva chama de simbólico. Féral opõe diretamente a performance a atividades desse tipo, elas desfazem e desconstróem competências, códigos e estruturas do teatral. Apesar de começarem por materiais do teatro - códigos, corpos vistos como sujeitos, ações e objetos envolvendo um sentido em sua representação - elas quebram os sentidos e as relações representacionais para permitir o livre fluxo da experiência e do desejo." 24
\end{abstract}

Primeiramente, temos como base de criação a noção de um sujeito como essência psico-física de reprodução. Considerando-se todo esforço de recontextualização histórica que tentamos apresentar, não é necessário pontuar novamente a que tipo de atuação Stansilavski se opunha e de quais ferramentas científicas dispunha para justificar seu retorno ao comportamento cotidiano na busca por novos sentidos para a vida cênica.

O ator pré stanislavskiano encontrava se no limite da reprodução estilística e da falta de um pensamento sistemático sobre os procedimentos de criação que

\footnotetext{
${ }^{124}$ Carlson apud Féral, Performance a critical introduction., p.151.
} 
possibilitasse a profissionalização para além do trabalho sobre os talentos pessoais. Com suas técnicas, a reconstrução de comportamento tornou-se um processo, mais do que criativo, pedagógico, que revelou possibilidades de transformação e mimese corporal em níveis até então operados muito mais por intuição do que propriamente por uma técnica organizada.

O sujeito como essência psicofísica surge como resposta ao tipo, se aceitarmos a afirmação de Féral de que, ainda aqui, o objeto/ obra pronta é o mais importante, pois estaríamos tratando de arte moderna por excelência. O ator é o sujeito que empresta seu corpo depoente para a criação do autor e todos os exercícios de seu método se orientam, em última instância, para movimentar o devir-personagem. Analisemos com mais atenção as relações-chave que envolvem o processo interpretativo.

O texto dramático é um estrato orgânico impregnado das memórias do escritor, um depoimento pessoal do autor que toma a narrativa como pretexto para delimitar o vértice-presente de seu cone da memória, e caracterizar as forças que atuam sobre sua criação. A fábula tem como ponto central a complexidade psicofísica das personagens, suas relações, transformações, em suma, toda trajetória humana e histórica, que pressiona a memória do autor para formação de um certo tipo de texto, de estética, de personagem e não outro.

A dramaturgia é a livre atualização dos virtuais pelas circunstâncias da fábula e de suas regras internas presentes de potenciação. Portanto, é uma recriação assumida enquanto tal de figuras ficcionais oriundas da memória do autor combinadas criativamente em devir. Não é um rememorar imagens do passado, mas recombinar seus virtuais que tenham poder de relação com as 
necessidades presentificadas do processo, suas memórias em rizoma com as intuições e impressões acerca da criação que ganharão forma no espaço pelo corpo do intérprete.

O ator é o corpo depoente que no método interpretativo pretende se apresentar como o meio de revelação da personagem. Falamos, utilizando ainda a terminologia do período, de uma essência que coloca seu aparato físico e psíquico em trabalho para produzir a expressão de outra essência. Todo sistema de Stanislavski reúne técnicas para conseguir alinhar os comportamentos das duas essências, em outras palavras, das duas máquinas poéticas, e promover uma atualização mimética dos virtuais que identificam a personagem pra o ator.

Por isso a criação de exercícios tão específicos para a construção dessa "verdade interior". As unidades, os objetivos, além dos operadores principais, existem para definir com o máximo rigor os limites da história para a qual o ator irá "emprestar" suas emoções. Elas direcionam o fluxo para as circunstâncias dadas e, assim, vão condicionando cada vez mais as respostas da memória às particularidades da narrativa, até que se delineie um perfil específico de criação conformada às forças do "se mágico", das circunstâncias, dos objetivos, e superobjetivo, etc.

Mesmo partindo de um pensamento que pretende conduzir um sujeito fenomenológico ao encontro de outra entidade fenomenológica, todo método stanislavskiano não é nada mais do que o desejo de se colocar em devir, um devir que, ainda que atualizado por coordenadas rigorosas de criação, tensiona a noção de essência apresentada de início. O texto dramático deseja ser corpo do ator/tradutor/traidor. A memória do ator deseja ser através da personagem/ corpo 
do autor e pelo corpo do intérprete (só assim ela pode ser nesse processo). É na afetação mútua de todas essas forças, na confluência dos desejos e em seu ultrapassamento que surge a personagem/ depoimento, síntese de depoimentos em devir, fluxo de corpos depoentes em relação rizomática com os demais corpos da performance.

O que Stanislavski inclina, à princípio, mais ao âmbito da imaginação, e que constitui a diretriz mais importante do método, a fabulação, é de fato uma função precisa da memória como recriação do vivido e da imaginação juntas quando tomadas como processo de cooperação rizomática e não mais como faculdades arborescentes. Quando pede para um ator se perguntar o que faria se estivesse em tal situação, Stanislavski é ilustrativo. Ele não sugere um retorno ao passado, nem uma evocação da experiência, pois muitas vezes o ator não vivenciou nem de perto a circunstância indicada.

Mais do que isso, ele sabe que o vivido ontem não voltará para auxiliar o ator hoje nem mesmo se mente e vontade estiverem no máximo de concentração. Vejamos essa bela passagem em que o autor toma literalmente a memória como recriação:

“O mesmo sucede no arquivo de nossa memória. Também nesse
existem armários e subdivisões. Algumas são mais acessíveis que
outras. Como recuperar as pérolas das lembranças emotivas que
fulguram por um momento como meteoros para desaparecer em
seguida? Quando aparecem e nos iluminam [...] agradecemos a
Apolo por ter nos enviado tais visões; mas não sonhemos em
fazer retornar o sentimento desaparecido para sempre. Amanhã,
haverá alguma outra recordação. Mas não esperemos pelo ontem,
e demos graças pelo dia de hoje. Somente quando receber
adequadamente as recordações que ressurgem, o espírito
responderá com renovada energia às partes do papel que
deixaram de emocioná-lo devido à repetição constante. Nos
entusiasmaremos, e talvez, então, apareça a inspiração. Mas, não
pense em perseguir a antiga pérola, que não voltarájamais, como
o ontem, ou a alegria da infância, ou o primeiro amor. Procure 
criar cada vez uma inspiração nova e fresca para o presente. Não importa que seja mais frágil que a de ontem: pertence ao dia de hoje. 125

Chegamos ao ponto chave do estudo da memória no método interpretativo em nossa tese. A noção de memória em Stanislavski não é, e não pode ser pela natureza de seu sistema, uma memória de evocação. Toda pedagogia stanislavskiana se baseia na ação, mesmo no período inicial em que as pesquisas se concentram na delimitação dos operadores psíquicos, abordagem da qual derivam os conceitos de memória das sensações, memória das emoções e imaginação.

A observação dos comportamentos psico físicos do ator logo revelou os limites de reprodução da performance como a principal questão a ser pensada em termos de uma atuação viva ou mecânica. Tais limitações têm como origem exatamente a natureza fugidia e ineficiente da memória quando compreendida somente como resgate histórico.

A memória das emoções é o operador que representa precisamente esse dilema: é preciso alimentar o repertório de vivências que se traduzem em imagens e sensações, e paradoxalmente aceitar que eles não se apresentam à nossa disposição pela força da vontade direta. A solução que Stanisalvski nos apresenta: aceitar a potência inata da memória e os produtos que ela nos oferece pela sua natureza criadora, e não restauradora e conformada às ordens racionais. Trabalhar a memória como ferramenta analógica, como fundida à imaginação em sua força criadora, cujas combinações não se submetem a lógicas comportamentais ou históricas apriorísticas e nem podem ser coagidas a agenciamentos de causa e

\footnotetext{
${ }^{125}$ El Trabajo de Actor sobre si mismo - el trabajo sobre si mismo em el proceso creador de las vivencias, $\mathrm{p}$. 231 .
} 
efeito, busca e encontro, etc. Por isso todo caminho de estimulação é indireto, pois um caminho de acesso direto à memória das emoções pressuporia relações de realização e não de atualização (criadoras), como já vimos anteriormente.

Nesse sentido, ainda, Stanislavski pontua em toda descrição de seu método a crescente valoração da relação objetiva do ator com os elementos da cena como base para recriação da vida cênica. Ela denota ao princípio da atenção e a todas as técnicas que dilatam a percepção, mas se estende também ao trabalho sobre as memórias. É da relação presente com os demais corpos da cena que surge a "inspiração" a que o pedagogo se refere para recuperar o frescor da performance. Stanislavski intuiu que a personagem, mesmo já construída, "fechada" como obra pretensamente pronta, acúmulo de depoimentos organizados, só respira e vive de fato quando o ator aceita o fluxo mnemônico e reconstrói sua identidade a cada apresentação no devir da mnemo criação e dos agenciamentos com os demais estratos da performance.

Ele exige exatamente que se assuma a criação, ou, em outras palavras, a memória como criação, como parte já da imaginação, a face líquida pela qual o estrato personagem se desterritorializa em ator-lembrança, ator-fábula, atorpercepção. Não interessa se a situação " $x$ " foi de fato vivenciada ou não pelo intérprete, ou algo semelhante, etc. A força não está na identificação pela capacidade de relembrar algo semelhante e estimulante à situação dramática. A chave está na capacidade de identificação com a criação que é a personagem, pela atuação da memória das emoções e sensações e da imaginação como complementares, e em acreditar com tanta verdade nessa criação que, por essa fé cênica, ela se torna real. Acreditar na fábula como se fosse real, pela depuração dos 
elementos da narrativa que qualificam a personagem, eis a ética do método interpretativo que promoveu a criação de todas suas ferramentas.

$\mathrm{O}$ depoimento pessoal do ator é o produto da pressão sobre o ponto $\mathrm{P}$ / personagem de uma memória das emoções (e das sensações) que se desloca dentro de um turbilhão. A fábula funciona como um pretexto afetivo para o ator potencializar seus desejos e se colocar em zona com todo domínio em devir da personagem, que conforma os desejos às circunstâncias cada vez mais definidas pelo texto. Mas as linhas de fuga são inevitáveis, e por isso os mesmos papéis são apresentados de formas tão distintas ao longo dos séculos mesmo em orientações estéticas idênticas. A memória é atualização e virtualização, não segue regras de probabilidade para evocação: cada memória é um fluxo de criação com relações singulares. Stanislvaski intuiu tais considerações imediatamente em seu rigoroso trabalho sobre os corpos depoentes, às quais respondeu brilhantemente com o instrumental de que dspunha em sua época. Sua pesquisa, que inicia e acaba no corpo, jamais o conduzira a teorias interpretativas transcendentais

Cada corpo depoente é um estrato em relações rizomáticas fluidas, mas heterogêneas. Os agenciamentos são irrepetíveis, as forças de pressão imensuráveis, todo processo é absolutamente particular, e aí encontramos uma noção de pessoalidade líquida que pode de fato contribuir para compreendermos as especificidades que envolvem a criação mesmo em processos que se pretendem fechados.

Após tantas considerações, acreditamos que seja o caso de repensarmos em que medida Stanislavski propôs um trabalho do ator que vê na personagem uma obra fechada A evolução de sua trajetória pedagógica, a transformação pelas quais 
passou seu método, a enorme intuição sobre os desdobramentos possíveis para as técnicas criadas e a atitude pessoal do pesquisador em seus registros parece apontar exatamente um interesse maior pelo processo e o temor de que a sistematização pudesse conduzir ao engessamento da pesquisa. Se a cena realista aparentemente concentra os cânones da teatralidade e da modernidade para o bem ou para o mal, o pensamento de Stanislavski sobre o trabalho do ator corre por outras regiões, e chega à atualidade com fôlego para um diálogo absolutamente potente com os criadores pós-modernos. 
Capítulo II - Os impulsos, ancestralidade e criação na cena- depoimento do performer: Grotowski e o ato total.

J erzy Grotowski (1933-1999) foi, provavelmente o maior pedagogo das artes do ator da segunda metade do século passado. Partindo dos relatos de Stanislavski e Vassili Toporkov sobre os processos de criação que se utilizaram do Método das Ações Físicas, associado à teoria dos jogos teatrais, à psicologia e etnologia do pósguerra e as tradições de representação orientais, indígenas e africanas, desenvolveu uma longa investigação sobre o trabalho do performer voltada para a essência técnica da atuaçãa

\begin{abstract}
"Criei-me com o método de Stanislavski; seu estudo persistente, sua renovação sistemática dos métodos de observação e seu relacionamento dialético com seu próprio trabalho anterior fizeram dele meu ideal pessoal. Stanislavski investigou os problemas metodológicos fundamentais. Nossas soluções, contudo, diferem profundamente das suas; por vezes, atingimos conclusões opostas [...] o mais importante para os meus objetivos: exercícios de ritmo, de Dullin, investigações das reações introversivas e extroversivas de Delsarte, trabalho de Stanislavski sobre as 'ações físicas', treinamento biomecânico de Meyerhold, a síntese de Vakhtângov. Também especialmente estimulantes para mim foram as técnicas do teatro oriental, especialmente a Ópera de Pequim, o Kathakali indiano e o Nô japonês. "’26
\end{abstract}

Sua abordagem parte da idéia de que a instrumentalização não se dá pelo acúmulo de conhecimentos e virtudes expressivas, senão o contrário, pelo despojamento de tudo que impede o fluxo dos impulsos internos e sua manifestação no corpo, a verdadeira fonte de expressividade cênica. Veremos como essa premissa pedagógica levou a construção do depoimento pessoal à supressão da personagem e estabeleceu regras particulares para sua organização em cada etapa de suas atividades.

${ }^{126}$ Em Busca de um Teatro Pobre, p. 14. 
As investigações de Grotowski iniciam formalmente em 1959, primeiro no pequeno Teatr 13 Rzedow (Teatro das 13 Fileiras), em Opole, seguindo após sua transferência para a cidade de Wroclaw (Polônia, sua terra natal), onde se estabelece oTeatro- Laboratório em condições mais estáveis de produção. Décadas mais tarde, após um período morando nos Estados Unidos, Grotowski se mudaria para a pequena cidade de Pontedera, na Itália, onde cria, com um de seus discípulos norte-americanos, Thomas Richards, o Centro para a Experimentação do Trabalho do Ator (Workcenter) de Pontedera. Ali, ele trabalhou até a sua morte, e pôde desenvolver os experimentos ulteriores que produziram a derradeira etapa de sua trajetória de investigação, em que a identidade do teatro se revela, paradoxalmente, pela recusa dos estatutos que a princípio definem a comunicação teatral.

Como sucedeu com Stanislavski, cada fase representa o aprofundamento do olhar que parte do trabalho do ator para determinar as demais semioses da cena, com a diferença de que, em Grotowski, a própria noção de teatro muda radicalmente pelos desdobramentos das experiências. Em seu artigo Da companhia teatral à arte como veículo, o pedagogo situa as etapas inicial e final como extremos de uma mesma busca pedagógica que pretende encontrar o verdadeiro sentido para o teatro como espaço de vida que se afirma pela negação de seu oposto, o jogo degradado das máscara cotidianas: "representamos tão completamente na vida que, para fazer teatro, bastaria cessar a representação."127 Eainda:

"Tais indícios nos levam a pensar, e o cremos sem despropósitos, que talvez Grotowski buscasse no teatro muito mais uma forma

${ }^{127}$ O Teatro Laboratório de Jerzy Grotowski 1959-1969. p. 1. 
de vida - que se poderia qualificar de autêntica ou de íntegra do que uma realização dramática tradicional. Pois a primeira constatação que enuncia em 'Em Busca de um Teatro Pobre' diz que o ritmo de vida da civilização moderna se caracteriza justamente pelos atos demasiadamente medidos, por tensões, por um sentimento de predestinação e morte, pelo desejo de ocultar os verdadeiros motivos pessoais e assumir, ao contrário, uma variedade de papéis e de máscaras Ou seja, na vida corriqueira, já somo atores. E o que oferece o teatro em contrapartida? Para aquele que sai do papel trivial da vida para consagrar-se ao papel reservado da cena, a arte dramática permite dedicar-se a motivos mais elevados, autoriza a retirada das máscaras sociais e torna possível uma ação completa, qual seja, a de uma união física e espiritual." 228

A primeira fase de trabalho recebeu do próprio diretor, no mesmo artigo, a classificação de arte como representação (ou teatro dos espetáculos) e acontece tanto na ocupação de Opole quanto em Wroclaw. Tem essa denominação porque o eixo da montagem dos materiais está na percepção do espectador e nos efeitos que se deseja oferecer ao público. Toda arte do espetáculo ou que se pretende espetacular, para Grotowski, parte dessa abordagem:

\begin{abstract}
"Normalmente, no teatro (bem dizer, no teatro dos espetáculos, na 'arte como representação", se trabalha a visão que aparece na percepção do espectador. Se todos os elementos do espetáculo estão elaborados e perfeitamente montados (a montagem), aparecerá na percepção do espectador um efeito, uma visão, uma história; de certa maneira, o espetáculo aparece não no cenário, mas na percepção do espectador. Esta é a particularidade da 'arte como representação'."129
\end{abstract}

Foi o período das encenações históricas ${ }^{130}$ do Teatro-laboratório, que revelaram à comunidade artística internacional as premissas artísticas e pedagógicas do que o autor polonês Ludwik Flaszen classifica como o pensamento do "arqueo" ou "paleo" Grotowski: o proto- estatuto do performer e da cena

\footnotetext{
${ }^{128}$ Miranda in op. cit., pp. 1-2.

${ }^{129}$ De la compañia Teatral a El arte como vehículo, p.158. Traduções minhas para todas as citações.

${ }^{130}$ Para uma introdução à teatrografia de Grotowski, ver O Teatro Laboratório de Jerzy Grotowski 1959. 1969.
} 
desenvolvido na fase dos espetáculos. Tais obras já continham os pilares de seu método: a transformação radical na forma de pensar a relação com o público (fim da quarta parede e questionamento sobre a necessidade e função dos espaços que separam atores e público, que produz o "participáculo", posteriormente abandonado na fase da arte como veículo) e a substituição da interpretação pelo Ato integral; pilares que se representam nos binômios ator- espectador e corpo-voz.

O ator-espectador é a expressão que Grotowski encontrou para definir a terceira entidade que nasce do encontro performático que o espetáculo proporciona, uma macro consciência global reflexiva que, na fenomenologia mística inicial do pedagogo se traduz num essencialismo transcendental, mas que no quadro de referência que viemos utilizando pode se definir mais complexamente como o agenciamento entre estrato-público e estrato espetáculo em rizoma no tempo poético do encontro. Essa terceira identidade se construiu de maneiras diferentes conforme as dinâmicas de interação entre público e atores ao longo da trajetónia de suas investigações. Voltaremos a essa questão fundamental com mais atenção adiante.

No período dos espetáculos, o performer aparece como o ator nãorepresentante, livre depoente, de forte presença física, que se insere no fluxo de imagens e intuições pela potenciação dos estados subconscientes levada ao limite da linguagem, e que é melhor representado na figura de Ryzsárd Cieslak, principal colaborador de Grotowski na época. Cieslak permaneceu com Grotowki em quase toda sua carreira, e vivenciou a evolução dos experimentos que configuraram as bases dos treinamentos técnico, plástico, vocal e energético . 
Grotowski parte da máxima contracultural de que o corpo do homem moderno é "podado" por práticas de educação coibitivas e coercitivas e máscaras sociais deformadoras. Funciona muito aquém de suas potencialidades expressivas, e nessa negação de si mesmo se encaminha cada vez mais para a morte. A esse sujeito em devir morte pela pressão das forças conservadoras que organizam o cotidiano, Grotowski denomina o "eu apreendido", cuja função do artista de teatro é “superar e desmentir."131

O conceito de impulso interior vem da análise freudiana, retomada por J ung em sua teoria do inconsciente, mas que sugere a Grotowski sua própria revisão do conceito a serviço da criação performática, que ele re denomina morfema: o morfema são as informações genuínas e expressivas de nossa estrutura psíquica que vêm mais diretamente do subconsciente e driblam o filtro auto-crítico e castrador do superego para atingir o exterior. São informações/sensações prélingüísticas, que compõem o material profundo e autêntico do depoimento pessoal do performer. Porém, tais informações já são corpo, se apresentam imediatamente à atualização da matéria quando se agenciam a um estrato orgânico humano livre de condicionamentos, em zona com os impulsos:

\begin{abstract}
“Nosso método não é dedutivo, não se baseia em uma coleção de habilidades. Tudo está concentrado no amadurecimento do ator, que é expresso por uma tensão levada ao extremo, por um completo despojamento, pelo desnudamento do que há de mais íntimo - tudo isto sem o menor traço de egoísmo ou de auto satisfação. $\mathrm{O}$ ator faz uma total doação de si mesmo. Esta é uma técnica de "transe", de integração de todos os poderes corporais e psíquicos do ator, os quais emergem do mais íntimo do seu ser e do seu instinto, explodindo numa espécie de "transiluminação". Não educamos um ator, em nosso teatro, ensinando-lhe alguma coisa: tentamos eliminar a resistência de seu organismo a este processo psíquico. O resultado é a eliminação do lapso de tempo entre impulso interior e relação exterior, de modo que o impulso
\end{abstract}

${ }^{131}$ De Mistério a Mistério: algumas observações em abertura, in op. cit., p. 26. 
se torna já uma reação exterior. Impulso e ação são concomitantes: o corpo se desvanece, queima e o espectador assiste a uma série de impulsos visíveis. Nosso caminho é uma via negativa132, não uma coleção de técnicas, se sim uma erradicação de bloqueios. "’33

Notemos que, mesmo que se tome como eixo de montagem a percepção do espectador, a encenação forma se pela disposição dos materiais do performer, que, nesse caso, se apresentam no limite da linguagem. Reconhece-se, desde já, a indicação do princípio que, como veremos adiante, conduziu à etapa ulterior de sua trajetória, classificada por Peter Brook como arte como veículo: os materiais pessoais do performer como centro da macro-criação e a gradativa assunção da montagem pelo próprio performer e para sua percepção, que redefine os privilégios na criação do depoimento.

Como vimos no trecho acima, o performer de Grotowski atua em um paradoxo de presença e ausência bastante singular. Ele é a presença física absoluta e potente que comanda os fluxos do espetáculo pela intensa ativação energética, o ator dilatado, ágil, apto a encontrar direcionamentos imediatos aos devires orgânicos e psíquicos da cena. Porém, seu objetivo final parece ser o de se tornar invisível como indivíduo, ausência enquanto sujeito material e caminho pelo qual os impulsos dançam na carne e fluidificam o "eu apreendido"-ator e o "eu apreendido"-público, numa síntese que não se sustenta mais por um pensamento essencialista:

\footnotetext{
${ }^{132}$ A via negativa, ou caminho negativo, é um dogma que Grotowski toma emprestado da teologia apofática cristã para transformar em princípio de orientação prático e ético. "Esse caminho em direção à Causa de Todas as Coisas exige o progressivo abandono de tudo aquilo que é conhecível e conhecido, junto com os instrumentos comuns do conhecimento, como, por exemplo, a linguagem discursiva. Aqui, se avança através da negação e do princípio da ignorância." De Mistério a Mistério: algumas observações em abertura, in op. cit., p. 30.

${ }^{133}$ Em Busca de um Teatro Pobre, pp. 14-15.
} 


\begin{abstract}
"É como se Grotowski fugisse do si mesmo definível: procurava o ator que não fosse ator, a atuação que não fosse atuação, o ensinamento que fosse desaprender. [...] Na caça ao Mistério do Vivente ('corrente de vida' é um dos seus termos 'técnicos'), mudava as modalidades de trabalho e procurava as palavras que denominassem mais fielmente possível a fluida tangibilidade da experiência. O Grotowski prático é um homem em perene perseguição das palavras..."134
\end{abstract}

A atuação, no sentido da autonomia de criação, caminha para a superação radical do ator tradicional, cujo depoimento se constrói a serviço do terceiro e condicionado aos discursos dramáticos e estéticos do dramaturgo e do diretor. A personagem não ocupa o espaço de uma essência ficcional que serve como estímulo, pretexto e álibi para a exposição do depoimento do autor, do diretor e do ator, mas o performer tem status para assumir seu depoimento/fluxo como linguagem pessoal, cuja sistematização não obedece à semiótica do espectador. O corpo cotidiano psicologizado e fenomenológico, delimitação material do sujeito como essência coagida e contida pelo superego, se destrói pela hiperativação e desaparece em relação rizomática com os estratos específicos da macro-criação pela orientação do diretor.

Nesse processo, Grotowski repensou a rotina de trabalho do performer em termos verdadeiramente revolucionários dentro do quadro histórico de procedimentos do teatro ocidental moderno, criando o primeiro sistema com consistência pedagógica suficiente para se apresentar como alternativa àquele de Stanislavski. Mesmo que ao final de suas atividades, o pedagogo duvidasse , e em parte, negasse, alguns apontamentos fundamentais sobre a eficácia do treinamento no período de ocupação do Teatro Laboratório, acreditamos que são contribuições irreversíveis ao quadro evolutivo das práticas do performer moderno e pós-

\footnotetext{
${ }^{134}$ De Mistério a Mistério: algumas observações em abertura, in op. cit., p. 19.
} 
moderno, e que seu resgate não pode ser ignorado na análise do pensamento do diretor.

O treinamento é a rotina de atividades pelas quais o performer pesquisa e organiza o trabalho sobre seus morfemas, em outra palavras, encontra a técnica pessoal que serve de caminho para o ultrapassamento do eu apreendido. O caminho para tanto que persistiu no método foi a busca da alteração energética. $\mathrm{O}$ treinamento energético toma a exaustão física como via para a derrubada das fronteiras da atividade consciente e libertação dos impulsos pela destruição dos limites da carne. A "combustão da matéria cotidiana" deseja colocar o performer em zona com estados não cotidianos, não-apreendidos, para reaplicarmos a terminologia do autor, já que, pelos pensamentos arborescentes que influenciam Grotowski, a corrente criadora como interioridade se movimenta sempre no trânsito entre as instâncias da consciência e da subconsciência. Os atores repetem estruturas de movimento e de ações em que se alternam passagens pelo chão, saltos, acrobacias, até que todo movimento pré codificado se transformasse em uma dança particular, iluminada pelas imagens interiores acessadas.

Detenhamo-nos, novamente, na problemática do paradoxo do performer. Como já esclarecemos, todos os procedimentos de treinamento e criação pretendem aparentemente conduzir a um mergulho cada vez mais "vertical" no repertório subconsciente, e permitir a atualização das memórias para além das questões da dramaturgia, revelando os impulsos mais interiores. Mas essa verticalização provoca imediatamente uma contra força complementar horizontal.

Em que termos? O desnudamento do ator se apresenta como a qualidade performativa que revelaria a humanidade por trás das particularidades do sujeito e 
movimentaria os fluxos para a comunhão reflexiva e afetiva entre os participantes da performance. O performer mergulha cada vez mais na sua "essência" para encontrar os impulsos que remetem ao imaginário e à memória comuns, uma essência coletiva e ancestral. Notemos a questão da ancestralidade que é cara Grotowski e revela sua noção última de memória criadora:

\begin{abstract}
“Um dos acessos à via criativa consiste em descobrir em si mesmo uma corporeidade antiga à qual se está unido por uma relação ancestral forte. Então, você não se encontra na personagem, nem na não-personagem. A partir dos detalhes, se pode descobrir em si o outro - o avô, a mãe. Uma foto, uma recordação amarrotada, o eco longínquo de uma tonalidade vocal permite reconstruir uma corporeidade. No começo, a corporeidade de alguém conhecido, e, depois mais longe, a corporeidade do desconhecido, do ancestral. É verídica ou não? Talvez não é como tenha sido, senão como poderia ter sido. Pode-se chegar a um passado muito distante, como se a memória despertasses. é um fenômenos de reminiscência, como se lembrasse ao performer do ritual primário. Cada vez que descubro algo, tenho a sensação de que é isso que recordo. As descobertas estão atrás de nós, e é necessário fazermos uma viagem pra trás para chegarmo s até elas.135
\end{abstract}

Ipsis literis, Grotowski sugere que o caminho da revelação do transindividual se dá menos como criação e mais como partida rumo ao passado oculto pelos comportamentos do homem moderno. A memória coletiva é sugerida como memória arqueológica, categoria transcendental, identidade coletiva perdida em algum ponto na passagem para o comportamento civilizado.

A criação, a auto-revelação, é o encontro com as imagens que compõem o imaginário e a memória comuns. Ela consiste, a princípio, no trabalho sobre o performer como essência individual que se coloca em zona pela destruição das pessoalidades da carne rumo à macro essência das interioridades coletivas em suspensão. Nesse "sacrifício" do sujeito, se utiliza de um jogo de distanciamentos

${ }^{135}$ El performer, p. 155. 
em que treina simultaneamente o mergulho nessa investigação e o olhar exterior para seleção de materiais, que Grotowski ilustra com a metáfora de um pássaro que bica e outro que olha, ou o Eu-Eu.

\begin{abstract}
“Para nutrir a vida do Eu-Eu, o performer deve desenvolver não um organismo-massa, organismo de músculos, atlético, mas um organismo-canal, através do qual as forças circulam. O performer deve trabalhar uma estru tura precisa. Fazendo esforço, porque a persistência e o respeito aos detalhes são o rigor que permite fazer presente o Eu-Eu. As coisas a fazer devem ser exatas. Don't improvise, plea se!"136
\end{abstract}

Esse binômio surge na etapa da arte como veículo, quando Grotowski se concentra mais nos mecanismos que permitem ao performer realizar a seleção dos materiais e criar a action do que em levar ao público suas experiências. Porém, a supressão do encontro não exime a problemática por ele levantada em anos de investigação, nem apaga a contradição entre a metafísica do sujeito-essência expandido e a utopia do inconsciente coletivo como categoria transcendental arqueológica. O sujeito- essência- performer é o desejo de se tornar coletividade. Seu trabalho, como já vimos insistentemente, nada mais é que o esforço em diluir a essência/indivíduo original (organismo massa) para criação de um organismocanal.

O "mergulho vertical” na "interioridade" do sujeito visa, em última instância, seu ultrapassamento em direção à grande identidade coletiva, uma espécie de “devir humanidade" ao mesmo tempo romântico e iluminista, em que o resgate da ancestralidade coletiva restauraria os laços de afetividade e consciência que nos unem numa macro-essência reflexiva. Nesse contexto, parece uma antinomia imaginar que, sendo o próprio performer fluxo dos impulsos e desejo de destruição

\footnotetext{
${ }^{136}$ Op. cit., p. 155.
} 
e reconstrução dos adensamentos rumo a uma consciência mais evoluída, a memória, a imaginação e a ação permaneçam como categorias perdidas em algum espaço misterioso da mente.

Também elas são fluidas, não podem ser tomadas como estruturas ingênuas e arcaicas cristalizadas, que remetem ao tempo em que o homem era mais "humano". Se a função da performance como ritual de comunhão é aqui radicalizada, é preciso que se tome a tradição das relações humanas como atualização do vivido em criação permanente no tempo, que se assuma a complexidade de tais relações que hora se estreitam ora se estendem, e que por essas diferenciações definem a existência da humanidade para além das individuações. Tal antinomia, Grotowski reconhece e indica a correção no desenvolver de suas pesquisas:

\begin{abstract}
"A convergência entre a minha definição teatral-doméstica do arquétipo e a teoria dos arquétipos de J ung é muito imprecisa; uso a palavra "arquétipo" em um sentido restrito, sem o background filosófico junguiano, não presumo a incognoscibilidade do arquétipo nem que ele exista fora da história. Etc. O termo "inconsciente coletivo" não significa nesse caso (diferentemente da escola de J ung) alguma psique superindividual, mas funciona como uma metáfora operacional; trata-se da possibilidade de influir sobre a esfera consciente da vida humana em escala coletiva. [...] Então, levamos o arquétipo do "inconsciente coletivo" para a consciência coletiva, o tornamos laico, o utilizamos como modelo-metáfora da situação do homem. Atribuímos-lhe uma função cognitiva, ou mesmo talvez - uma função do livre pensamento."137
\end{abstract}

Ainda que mantenha a noção de uma consciência coletiva transcendental, Grotowski reverte a função de inconsciente coletivo como operador de transformações das consciências individuais, e não como um espaço de

${ }^{137}$ A Possibilidade do Teatro, in O Teatro de Jerzy Grotowski 1959-1969, pp. 51-52. Grifos meus. 
contemplação da atividade subconsciente dos sujeitos em suspensão. Essa perspectiva altera completamente a ontologia da criação no método, e contempla muito mais o caráter processual que envolve a formação das relações e seus produtos no "participáculo". O inconsciente não é uma esfera de afetação, mas um agente pulsante que sintetiza as transformações humanas em escala transindividual. Ele não é somente alterado pelo ritual teatral, mas retro-alimenta as consciências participantes em rizoma, desdobrando no tempo o fluxo do processo e problematizando-o.

O arquétipo, outro termo caro e de importância central no tratamento da memória no sistema, também se reconfigura distintamente da teoria junguiana pelas demandas do método. Grotowski chama "dialética da derrisão e da apoteose"138 a essa espécie de antropofagia do conceito que é executada para dar conta dos efeitos da criação:

\begin{abstract}
"Destilar do texto dramático ou plasmar sobre sua base o arquétipo, isto é, o símbolo, o mito, o motivo, a imagem radicada na tradição de uma dada comunidade nacional, cultural e semelhantes, que tenha mantido valor como espécie de metáfora, de modelo do destino humano, da situação do homem (...) A "dialética da derrisão e da apoteose tira o arquétipo do inconsciente coletivo dos dois ensembles para a consciência coletiva (superação da magia, da esfera da sombra, da laicização do arquétipo, sua utilização como modelo-metáfora da condição humana)."139
\end{abstract}

Lembremos a passagem final do texto Farsa Misterium ${ }^{140}$ : "a forma não funciona aqui como um fim em si, nem como um meio de "expressão" ou para ilustrar algo. A forma - a sua estrutura, a sua variabilidade, o seu jogo de

\footnotetext{
${ }^{138}$ A expressão foi forjada pelo crítico teatral Tadeusz Kudlínski para caracterizar a forma de tratamento do texto em função do trabalho com os performers nos processos de Grotowski.

${ }^{139}$ Op. cit., pp. 50 e 60.

${ }^{140}$ In O Teatro de Jerzy Grotowski 1959-1969, p 46.
} 
opostos (em uma única palavra, todos os aspectos tangíveis e técnicos da teatralidade de que se falou) - é um peculiar ato de conhecimento". Para Grotowski, o encontro teatral é a situação que autoriza e movimenta a produção de conhecimento em âmbito mais livre e intenso por excelência, o espaço em que os homens podem expor o que realmente são e pensam.

O espetáculo não é formalização apriorística fechada, mas a organização inicial dos impulsos do ensemble atores e dos discursos dos demais artistas criadores para colocar em devir a audiência, e pelo fluxo de tais agenciamentos construir as formas fluidas do que ainda persiste como "espetáculo", mas que, de fato, é processo de formação de conhecimento em adensamentos singulares e em devir. O arquétipo como categoria transcendental ultrapassa sua função referencial para também tornar-se um operador na criação dos conhecimentos intelectuais, sensoriais, afetivos que se criam pelo encontro. Na "dialética da derrisão e da apoteose", a transformação da natureza do conceito e a produção de conhecimento resultante de sua operação se dão criticamente, pela intensidade com que as imagens arquetípicas trabalham nas consciências quando provocadas. A memória passa da representação à ação, como princípio criador de novos pensares no ritual laico do jogo teatral:

\footnotetext{
“'A dialética da derrisão e da apoteose', atacando o arquétipo, faz vibrar toda cadeia de tabus, de convenções e de valores consagrados. Desse modo forma-se a cintilação do espetáculo: a roda de profanações, os estados sucessivos (ou os níveis) das contradições, as sucessivas e recíprocas antíteses, a sucessiva anulação dos tabus... que faz emergir na realidade um novo tabu (à rebours); e de novo a anulação..."141
}

${ }^{141}$ A Possibilidade do Teatro, in op. cit., p. 59. 
Como vemos, mesmo que se aceitasse inquestionavelmente as matrizes epistemológicas iniciais de Grotowski, o que, de fato, ele mesmo, como grande pedagogo não incorre no erro de fazer, o próprio andamento de suas pesquisas irá produzir um pensamento que demanda conceitos mais complexos para sua apreensão, cujo aperfeiçoamento terminológico Grotowski não se furta jamais em empreender. Forças horizontais pressionam o processo a uma cartografia, impõem dinâmicas horizontais de relação: o desdobramento ulterior do mergulho é, ainda aqui, a comunicação, o colocar em devir a audiência para o encontro com seus valores primeiros. O morfema não é evento, nem representação histórica, é exatamente a memória como criação no fluxo, seja no treinamento ou no encontro:

“O subscrito está de acordo com aqueles que considerem que a especificidade do espetáculo como obra de arte seja:

a) o contato vivo, imediato entre o espectador e o ator,

b) o ato coletivo; atores e espectadores como uma só coletividade, conjuntamente ativa, participante e interativa,

c) a ausência de uma forma fixada (impressa, em fita, sobre outro material); o devir no contato entre espectador e ator. "142

Por isso a insistência no trabalho sobre seqüências rigorosamente codificadas de ação e o repúdio à improvisação de ações livres ${ }^{143}$, a busca pela linguagem de impulsos do performer:

\footnotetext{
“Não se fala aqui de dança. Mas ela está presente na entrelinhas. E está presente algo que, um certo tempo, - seguindo Stanislavski - chamava-se de partitura do ator. No início, era a partitura de signos corporais e vocais, composta artificialmente. Depois, a partitura das "reações" fixadas, dos "pontos de contato", enfim, a reproduzível corrente de impulsos visíveis. A

142 Op. cit., p. 49. Grifos meus.

${ }^{143}$ De onde se desenvolve o conceito de gesto significativo, a menor unidade de expressão no método, e que se opõe ao gesto comum,
} 
organicidade em estado puro que é a zona intermediária entre o que é corporal e espiritual. O santo Graal de Grotowski. [...] O ato do ator compõe-se das reações vivas do seu organismo, da "corrente dos impulsos visíveis" no corpo. Todavia, para que esse processo orgânico não se desvie no caos, é necessária a estrutura que o canalize, a partitura composta do movimento e do som. "144

A desterritorialização pela crença do macro-sujeito líquido, ancestral, feito das memórias e das ações coletivas, que surge pelos agenciamentos afetivos e memoriosos promovidos pelo fluxo da performance é a tônica de uma possível semiótica autônoma do performer, mas que, como veremos na evolução das experiências rumo à etapa da arte como veículo, tende a isolar cada vez mais o instante de criação. O movimento das pesquisas pressiona o recorte essencialista ao limite do fenômeno da criação, e paradoxalmente, esse pretenso isolamento meditativo rumo às tradições funciona como um microscópio que amplia as qualidades do ator.

A noção de performer como a presença que potencializa o fluxo criador (para virar ausência) é um legado extremamente importante intuído por Grotowski, e que transcende as questões da autoralidade do discurso para discutir o peformer como máquina de criação e os termos que negociam a preparação do artista na performance moderna e pós-moderna. Para o pedagogo, a instrumentalização estava na base do processo, cujas técnicas não são exteriores ao homem, mas exatamente o oposto: se revelam à medida que o sujeito se despe de suas individualidades e, pelos devires a suas experiências mais ocultas, se ultrapassa rumo a uma macro-consciência afetiva e reflexiva global no agenciamento com o público.

\footnotetext{
${ }^{144}$ De Mistério a Mistério: algumas observações em abertura, in op. cit, pp. 27e 30.
} 
O procedimento complementar ao treinamento energético, o treinamento técnico, busca uma adequação dos materiais livremente criados nos exercícios energéticos aos apontamentos dramáticos, porém não de forma alinhada, como no sistema interpretativo tradicional. Às palavras de Grotowski: “buscamos algo do qual temos uma idéia inicial, um certo conceito. Se buscarmos com intensidade e consciência, talvez não o encontremos, mas algo diferente vai aparecer, que talvez possa reorientar completamente todo o trabalho."145

E, novamente, sobre a memória para o Ato:

\begin{abstract}
"Tomemos o Príncipe (O Príncipe Constante) interpretado por Riszárd Ciesak no Teatro-Laboratório. No trabalho do papel, antes de se encontrar com seus partners de espetáculo, durante meses e meses o ator trabalhou somente comigo. Nada em seu trabalho estava ligado ao martírio que no drama de Caldéron/ Slowacki é o tema da personagem do Príncipe constante. Toda a torrente de vida do ator estava ligada a uma recordação feliz, às ações pertencentes a essa recordação precisa de sua vida, às menores ações e impulsos físicos e vocais desse momento rememorado. Foi um momento de sua vida relativamente curto [...] O tempo amoroso de sua adolescência [...] Foi como se esse adolescente rememorado se libertasse com seu corpo de seu mesmo corpo, como se ele se libertasse, passo a passo, do peso do corpo, de todo seu aspecto doloroso. Através da multiplicidade de detalhes, de todos os pequenos impulsos e ações ligados a esse momento de sua vida, o ator encontrou o fluxo do texto de Calderón/ Slowacki." ${ }^{146}$
\end{abstract}

Eis a chave da questão: o método de Grotowski nos propõe novos vetores de atualização da memória distintos daqueles característicos do sistema interpretativo. Ao contrário do que sucede com o ator tradicional, a memória do performer não é pressionada a encontrar as recriações do vivido análogas aos eventos e comportamentos da personagem. A situação dramática, mediante esse tipo de treinamento, serve como um estímulo livre para o contato com os impulsos

\footnotetext{
${ }^{145}$ De la compañia Teatral a El arte como vehículo.

${ }^{146}$ Idem, ibidem, p. 9.
} 
criados não só pelo estudo do texto, mas por uma combinação deste com exercícios energéticos e técnicos específicos, que permitem o trabalho sobre conteúdos aparentemente dissonantes aos temas da peça, mas cujos sentidos são construídos pela linguagem dos impulsos estruturada em ações físicas precisas.

As ações físicas são a atualização veloz das criações mnemônicas, e possuem uma lógica discursiva e uma poética singulares, comprometidas com o fluxo criador do performer e seus agenciamentos processuais. Os morfemas são as unidades expressivas da memória atualizadas no Ato, o corpo está no limite da matéria e da memória, é corpo-depoimento, corpo-vida = corpo-memória. O Método das Ações Físicas de Stanislavski encontra suas respostas no corpo-memória de Grotowski:

\begin{abstract}
"Nosso corpo inteiro é uma grande memória e em nosso "corpomemória" criam-se pontos de partida. [...] Pensa-se que a memória seja algo de independente do resto do corpo. Na verdade, ao menos para os atores, é um pouco diferente. O corpo não tem memória, ele é memória. O que devem fazer é desbloquear o "corpo-memória". [...] O "corpo-vida" ou "corpomemória" determina o que fazer em relação a certas experiências ou ciclos de experiências de nossa vida [...] O corpo-memória: a totalidade do nosso ser. Mas quando dizemos "a totalidade do nosso ser", começamos a imergir, não na potencialidade, mas nas recordações, nas regiões da nostalgia. Eis porque talvez seja mais exato dizer corpo-vida."
\end{abstract}

O trecho acima foi extraído do texto "Exercícios", publicado no suplemento número 6 da revista Action cuturelle du sud est em 1971 e apresentado pela primeira vez em um encontro com estagiários estrangeiros no Teatro Laboratório em 1969. O conceito de corpo-memória que Grotowski nos apresenta nesse artigo significa a superação de todas as antinomias que o dualismo transcendentalista implicava no tratamento da memória como matriz dos morfemas até então, e é um passo definitivo no esclarecimento de suas funções no método. 
Na velocidade dos morfemas, memória é matéria, e ultrapassamento da matéria. O corpo-vida é o corpo animado pela manifestação das memórias, os impulsos, que, em última instância, não representam, mas são o sujeito verdadeiro que se revela, o eu não-apreendido libertado. Essa manifestação autêntica do sujeito é o Ato, o desnudamento completo, o mostrar-se por inteiro pela exposição imediata do corpo-memória nas unidades dos morfemas mediante estruturas rigorosas de ações (partituras) que canalizam o fluxo e identificam os depoimentos .

A dança da memória no corpo presente não tem começo nem fim, forma toda existência do homem enquanto ser criador, seja artista ou não. Mas o artista pode sistematizar o olhar sobre as particularidades da dança, que, em última análise, é o observar a si mesmo enquanto ser em formação no tempo de criação e expressão das memórias. A essa dança criadora do corpo-memória, Grotowski chama “acrobacia orgânica":

\footnotetext{
"Gradualmente, chegamos àquela que chamamos de "acrobacia orgânica", ditada por certas regiões do "corpo-memória", por certas intuições do corpo-vida. Cada um gera o seu modo e é aceito pelos outros do modo deles. ${ }^{147}$ Como crianças que procuram o modo de serem livres, de se liberarem dos limites do espaço e da gravidade. [...] Mas não finjamos ser crianças, porque não o somos. Porém, é possível reencontrar fontes análogas ou, talvez, até as mesmas fontes dentro de nós, podemos procurar aquela "acrobacia orgânica" (que não é acrobacia) que é individual e se refere a necessidades luminosas e vivas; isto é possível se não começamos ainda a morrer, pouco a pouco, renunciando ao desafio de nossa natureza. "' 148
}

Voltemos, ainda, à distinção entre “corpo-memória” e corpo-vida que Grotowski apresenta no final da citação anterior. Corpo vida é uma correção de “corpo-memória” no sentido de combater uma possível "nostalgia” atribuída ao

\footnotetext{
147 A acrobacia orgânica como linguagem do performer.

${ }^{148}$ Exercícios, in O Teatro Laboratório de Jerzy Grotowski 1959 - 1999, p. 178
} 
termo e que não condiz com a dinâmica de atualização dos morfemas. Ora, essa nostalgia está ligada exatamente à noção de memória como "ida ao passado", como resgate arqueológico de emoções, sensações, vivências, eventos fixados em algum ponto do passado na historiografia do sujeito. Compreende-se a necessidade de esclarecimento que Grotowski empreende nesse sentido: o corpo-memória é presente, é recriação do vivido nas circunstâncias do Ato, é fluxo para-racional em criação, e não deslocamento rumo às lembranças.

Grotowski nos oferece o corpo-vida como alternativa que dá conta de sua demanda terminológica imediata, mas cuja verdadeira resolução exige a revisão do conceito de memória. O corpo-vida é corpo-memória sem necessidade de maiores explicações, pois memória é atualização e virtualização como processos criadores, e o corpo é adensamento em devir que revela as singularidades de tal processo pela dança dos impulsos.

Em sua terminologia particular, que, evidentemente, ressoa o pensamento da modernidade, Grotowski intui, antecipa e indica os pontos principais da teoria do performer pós-moderno, sujeito em devir, corpo-memória em atualização e virtualização, dança das consciências. A construção do depoimento se liberta da ficção e se volta para a revelação direta, sem máscaras, sem as mediações fabulosas da interpretação, e aí está a total crueldade do sistema. O depoimento pessoal de Grotowski não permite álibis, não oferece anteparos, exige a assunção integral de seus conteúdos e forma. É, na melhor das definições, talhada pelo próprio pedagogo: uma confissão. Em Grotowski, depoimento pessoal = dança confessional. 
Ao diretor, ou espectador de profissão, cabe precisamente auxiliar o performer a desvelar a potência poética de sua dança confessional, e organizá la como linguagem autônoma. Mas, em última instância, são as lógicas específicas que se criam pela atividade do "corpo-memória" que conduzem todo processo, e exigem a libertação das sintaxes da cena que privilegiam a semiótica do espectador. É essa provocação que Grotowski propõe quando eleva o performer ao status de principal motor de linhas de fuga poéticas da cena pela crescente autonomia na produção dos depoimentos, e destrói a idéia de "espetáculo" strictu sensu.

A qualidade do encontro é a base de todo encaminhamento das investigações, e o período dos "participáculos" avança a um limite insustentável para os objetivos de Grotowski nesse sentido. Em seu artigo Teatro e Ritual, Grotowski relata os desvios do processo, cuja face mais contraditória diz respeito ao fortalecimento das máscaras cotidianas por arremedos de interpretações clichê, quando na participação dos espectadores como atores, revelava se um caminho diametralmente oposto ao quese pretendia:

\footnotetext{
"Mas nas reações dos espectadores, quando agiam como coatores, até mesmo liberando de si alguma espontaneidade, havia muito do velho teatro, velho não no sentido de velho-radicado, mas no sentido de teatro dos clichês, do estereótipo, da espontaneidade banal; apesar da estrutura do espetáculo, que possivelmente banal não era e que - como penso - podia, em certos casos, ser de inspiração." ${ }^{49}$
}

A participação do espectador diretamente como ator foi um recurso muito usado nos espetáculos como exercício para supressão da divisão ator-espectador tradicional. A busca pela re-organização das funções se transforma e surge em outros termos na etapa seguinte de suas pesquisas: o teatro da participação ou

\footnotetext{
${ }^{149}$ Teatro e Ritual, in op. cit., p. 122.
} 
para-teatro, mas cuja problemática já estava antecipada nas experiências de desterritorialização dos ensembles no "participáculo".

No para-teatro, o estudo específico sobre a atuação cede espaço à noção de revelação coletiva: a busca pelo Ato construído ativamente no ritual laico atorespectador. A participação ativa do público é tomada como o princípio para sua exposição, cujas limitações se revelariam pela própria estrutura do processo:

\begin{abstract}
"Quais foram as conclusões? Nos primeiros anos, quando um grupo trabalhava a fundo sobre isso, por meses e meses, e quando em seguida se uniam de fora só alguns novos participantes, aconteciam coisas no limite do milagre. Porém, quando depois, à luz dessas experiências, fizemos outras versões visando incluir mais participantes - ou quando o grupo de base não tinha passado antes por um longo período de trabalho intrépido - certos elementos funcionavam, mas o conjunto decaía bastante facilmente em uma sopa emotiva entre as pessoas, ou em uma espécie de animação"150
\end{abstract}

O aparente "fracasso" do para-teatro é riquíssimo, pois, se por um lado constitui um processo criativo dinâmico e particular que tem valor em si (sabe-se lá quão interessante poderia ter sido essa "sopa emotiva” a que Grotowski se refere conforme os critérios de enquadramento), por outro revela uma consideração de enorme importância para se apreender as complexidades da relação atorespectador: o testemunho como atividade criadora do público.

A princípio, a não- participação ativa do público nos espetáculos, delimitada pela separação palco-platéia, era vista com o peso da indesejada herança dos teatros nobres e burgueses, cuja hierarquia na disposição dos ensembles reproduz e legitima a ordem social vigente. Eis porque a persistência em levar ao limite a diluição de qualquer divisão que remetesse a tais organizações ea procura por

${ }^{150}$ Da la companhia teatral à arte como vehículo, pp. 230-231. 
novas relações da œena. Pela lógica do método, um caminho eficiente para tanto seria oferecer ao público técnicas de autopenetração e revelação semelhantes àquelas vivenciadas pelos performers, pois, por associação, os resultados deveriam ser análogos. A divisão do texto com o público e sua participação como co-atores, a proximidade entre atores e público e toda forma de interação que tirasse os espectadores de sua condição passiva era, então, a maneira aparentemente mais provável para estimular o desnudamento, o Ato coletivo.

Mas, como vimos, os produtos de tais experiências, para Grotowski, acabam por reafirmar exatamente o contrário do desejado: a restauração de novas máscaras e atitudes- clichês e o fluxo desordenado. Porém, indicam uma descoberta preciosa: a vocação do espectador. Essa vocação é o testemunho. A participação ativa exige inevitavelmente do público a vestimenta da máscara do ator com toda a precariedade de sua condição de amador, à qual ele não responde, muitas vezes, não por não se dispor ao Ato, mas pelas exigências próprias do tipo de relação que se impõem. É algo interessante no sentido de investigação improvisacional, mas que se contrapõe à orientação técnica e aos intuitos mais elementares do método estabelecidos até então.

É pelas particularidades do testemunho que o espectador consegue efetivamente se revelar e criar, em outras palavras, construir sua identidade no tempo do devir-ato ou devir-espetáculo:

"Quando, por exemplo, queremos dar ao espectador a possibilidade de uma participação emotiva, direta, mas emotiva, isso é a possibilidade de identificar-se com alguém que traz a responsabilidade da tragédia que se está desenvolvendo, então é preciso afastar os espectadores dos atores, não obstante aquilo que aparentemente poderíamos pensar. O espectador afastado no espaço, colocado na situação daquele que, como observador, não é sequer aceito, que permanece unicamente na posição de observador, é realmente capaz de co-participar emotivamente, 
uma vez que no fim das contas, pode reencontrar em si a original vocação do espectador. É preciso perguntar em que consiste aquela vocação do espectador, assim como pode-se perguntar qual é a vocação do ator. ${ }^{151}$

O poder de criação do espectador se dá no espaço da relação testemunhal com a cena, que é recolhida, mas não contemplativa. É no espaço das microinterações sutis onde ele encontra sua potência de participação, que não exige do espectador a brusca colocação de nenhuma outra máscara que o aprisione, que lhe force uma expressão para a qual ele não está preparado.

Observar e guardar, eis o binômio operacional de criação da testemunha. Respicio, a palavra latina que indica o respeito ao observado, que se dá exatamente pela não intromissão física. Recolhimento como sinal de respeito ao testemunhado e como caminho para a reflexão e forma de participação, e não como alienação da experiência:

\begin{abstract}
"A testemunha não é quem enfia por toda a parte o nariz, quem se esforça para ficar o mais próximo possível, ou por intrometerse nas ações dos outros. A testemunha mantém-se levemente à parte, não quer se misturar, deseja estar consciente, ver o que acontece do início ao fim, e guarda na memória; a imagem dos eventos deveria permanecer dentro dela [...] eis a função da verdadeira testemunha, não se intrometer com o próprio mísero papel, com aquela importuna demonstração "eu também", mas ser testemunha - ou seja, não esquecer, não esquecer, custe o que custar."152
\end{abstract}

O depoimento das testemunhas implica na memorização do depoimentoconfissão dos performers, e a cena ganha o status de grande tribunal em que se expõem e se avaliam os crimes morais da humanidade. O julgamento/cena é a dança macroscópica e microscópica das memórias reveladas e testemunhadas, que se constrói na simbiose entre a verdade da exposição e a sutileza recolhida da

\footnotetext{
${ }^{151}$ Teatro e Ritual, in op. cit., p. 122.

152 Op. cit., p. 123.
} 
observação. Essa é a máscara que carrega em si o potencial de autodestruição: a meta-máscara natural do espectador como espectador, com todas as micro-ações e micro-percepções orgânicas de tal função.

Tal constatação é definitiva para encaminhar a nova orientação que as investigações de Grotowski assumem a partir de então. Se o teatro é o ritual laico, então as bases desse ritual estão nas ações do performer e na participação cada vez mais delicada do espectador. A fé nessa premissa leva Grotowski à fronteira do estatuto das artes performativas, cuja derradeira conseqüência é seu desinteresse pelo teatro em si. Essa etapa das investigações cujos produtos e interesses não partem mais das relações ator-espectador ficou conhecida como arte como veículo.

Antes, porém, de entrarmos no trabalho sobre a memória nessa fase, houve uma pesquisa de outra natureza que a antecedeu e indicou o caminho que seria acolhido: o teatro das fontes. No teatro das fontes, os performers assumem o isolamento como procedimento de investigação das diferentes técnicas tradicionais e suas reverberações nos corpos. Retoma-se a pesquisa (de forma mais solitária) sobre as tradições de representação já tratadas desde o início da criação do método e os efeitos que tais técnicas exercem sobre cada ator, sobre suas memórias, sua percepção; individualmente, e na relação com o ambiente. Essa fase foi interrompida com a partida de Grotowski para os Estados Unidos, mas estabelece o modus operandi e as bases de estudo que irão orientar as atividades no período seguinte.

Na arte como veículo, a sede da montagem está no ator, ou, em melhor definição, no atuador, já que não mais se representa um papel a não ser o de si mesmo desnudado. O atuador é o fazedor, o performer ipsis literis, aquele que 
encontra nas ações e por elas os sentidos para sua organização. Não existe comprometimentos nem demandas exteriores a esse processo, não há semiótica, pois se suprimiu o testemunho do espectador. O trabalho radicalmente vertical sobre as memórias pessoais do performer, a crença na força expressiva das tradições e busca pelas manifestações de tais técnicas tradicionais nos corpos tornam-se o eixo da investigação. Eis porque, como dissemos anteriormente, aqui, Grotowski estreita ao máximo o recorte fenomenológico do encontro para detectar seus elementos mais essenciais, o que ele próprio classifica como "objetividade do ritual".

A memória como criação está aqui a serviço de uma prática que segue princípios éticos e técnicos bastante específicos de produção, que tomam as práticas ancestrais como modelo de exploração.

Os exercícios se utilizam exatamente de relatos orais e cantos rituais para "verticalizar" as técnicas exteriores. Essa transfusão se dá na passagem da percepção das melodias do som para a compreensão de suas qualidades vibratórias, e a partir de então pesquisar como tais forças atuam sobre os impulsos. As qualidades vibratórias s̃o, para Grotowski, como registros de impulsos antigos fixados em unidades fonéticas, cujo discurso energético subjacente à palavra é exatamente o ponto central de interesse das pesquisas. Os cantos são, assim, como conjuntos de técnicas transmitidos oralmente, pois cada fonema é um operador que atua sobre o performer liberando morfemas específicos, uma comunicação energética entre impulsos do passado (os cantos) e do presente (os morfemas).

Esse trabalho que parte das qualidades de vibração musicais para estudar suas respostas na criação dos morfemas produz partituras orgânicas muito pessoais 
e precisas, a que Grotowski chamou action. Cada action é uma estrutura performativa autônoma que é resultado de um processo individualizado de investigação: não há trocas entre actions ou quaisquer práticas que facilitem a semiotização das criações. Nesse sentido, nem mais é possível falar de uma linguagem do performer, a não ser do performer para si mesmo dentro do binômio Eu-eu.

A seleção das ações que se organizam na action não se dá de forma racional. A racionalidade ordena ações para criação da linguagem, em um caminho oposto ao das Actions. Awarness é o termo que define a consciência sensível pela qual o performer escolhe e ordena as unidades de sua estrutura, operacionalizada pela dinâmica de identificação e distanciamento do "Eu- eu”.

É delicado tratarmos do depoimento pessoal nessa etapa de trabalho de Grotowski em que está latente o desejo da não-comunicação, pelo menos nos termos da performatividade. Não há dúvidas de que esse giro radical de perspectiva se move pela sede incansável de chegar cada vez mais fundo na alma humana e atingir os depoimentos mais essenciais e protegidos.

A negação da fábula pronta não significa a afirmação do resgate histórico, mas reafirma a criação como método de comunicação entre gerações e como tônica da produção artística presente. Na arte como veículo, a tradição se comunica ao presente como criação, a atualização dos cantos rituais; e é recriada pelo performer na liberação de seus morfemas advindos da pesquisa com os cantos.

O trabalho sobre os cantos é a busca física pelas memórias ancestrais guardadas nas unidades de comunicação mais vivas e pulsantes, pois construídas pela linguagem da energia vibracional sonora: os fonemas. É a tentativa de 
encontrar, pela voz como memória energética atualizada dos antigos, os seus impulsos ancestrais, e conectá-los com os corpos-memória contemporâneos e seus morfemas singulares. Esse processo não deriva em linguagens, e nem esse parece ser o interesse do pedagogo. Suas motivações para conduzir por tanto tempo um pesquisa sobre a memória nesses termos? Objetivamente, Grotowski nos indica a contigüidade com o teatro e o desejo em desenvolver seu próprio método das ações físicas ${ }^{153}$. Mais longe, não podemos avançar, pois seu pensamento não permite especulações.

Desse ponto de vista, concluímos que, na arte como veículo, Grotowski encontra, finalmente, os mecanismos mais apropriados para investigar o que, de fato, sempre foi o objetivo maior de sua procura: o grande depoimento memorioso da humanidade.

\footnotetext{
${ }^{153}$ Ver At Work with Grotowski on Phisical Actions.
} 
Capítulo III - A memória nas performances de J oseph Beuys, Marina Abramovic e Spalding Gray.

Chegamos aos últimos estudos de caso levantados em nossa seleção que, como já vimos, ruma gradativamente de um depoimento pessoal mediado pela fábula (a personagem dramática) para a busca de um expressão cada vez mais autônoma dos conteúdos históricos do performer como responsável pela composição global da cena. Analisaremos, aqui, três exemplos de artistas da peformance art cujo tratamento da memória destaca-se na maneira muito autêntica de orientar os processos criativos e organizar o discurso cênico decorrente: J oseph Beuys, Spalding Gray e Marina Abramovic.

Joseph Beuys é um artista que, sem dúvida, ocupa posição central na evolução de uma nova arte em que o performer possa se colocar como depoente direto da cena. Para definir sua atividade, cunhou o termo aktion, que se diferencia do happening e da performance por fixar seu centro expressivo mais na ação do atuador-depoente do que no evento total ou no desempenho espetacular. Portanto, ainda que seu trabalho tenha se afirmado como exemplo de criatividade e autenticidade dentro da performance art, suas apresentações são mais fiéis ao pensamento de seu criador quando respondem à denominação aktions ao invés de performances.

A atividade artística de Beuys, nos primeiros anos, estava ligada mais diretamente às artes plásticas, especificamente à produção de desenhos e gravuras. O amadurecimento de tais experiências permitiu ultrapassar o suporte inicial e investigar as relações espaciais que desenvolvera no papel nas estruturas 
tridimensionais da matéria, de onde nasce seu intrigante conjunto de canto (Fettecke) e cadeira de gordura (Fettstuhl).

Antes de entrarmos especificamente na construção do depoimento pessoal revelado pelas aktions, analisemos outro aspecto importante no que tange à utilização da memória criadora na obra de Beuys: a relação com os materiais. Entre 1942 e 1943, quando ainda era um estudante recém formado em sua cidade natal, Cleves, na Alemanha, e muito antes de consolidar sua carreira como artista internacional, Beuys serviu ao exército alemão na segunda guerra. Conforme seu relato autobiográfico, por ocasião de um ataque aéreo sobre a península da Criméia, seu caça foi bombardeado e caiu no gelo, um acidente que lhe causou sérios ferimentos e resultou na morte instantânea de seu co-piloto. Beuys ficou preso no gelo, e foi resgatado por pastores tártaros que o imantaram com gordura animal para tentar curá-lo dos ferimentos e re- estabilizar sua temperatura interna até a chegada das tropas de resgate alemãs.

O teor de veracidade de tal relato não nos é possível restaurar. Mas o fato é que Beuys transformou a gordura em um dos principais signos de seu vocabulário plástico, ao qual logo incorporou o feltro como outro isolante igualmente expressivo para suas composições. Assim, o material gordura se desloca de sua história pessoal para gerar novos significados dentro da combinação de elementos que determina o discurso de suas obras. Em Fettshull, ela deforma o assento da cadeira para brincar tanto com a funcionalidade que pré-atribuímos aos objetos quanto com a temperatura do corpo e as transformações daí decorrentes na manutenção da energia e, conseqüentemente, da vida. Já em Fettecke, o canto da sala interditado pela gordura geometricamente disposta faz lembrar tudo que é 
deixado de lado e se acumula negativamente no corpo e na mente, e questiona a escravidão ao acúmulo e ao apego característica do homem moderno ocidental.

A identificação de Beuys com os materiais isolantes pode ter nascido tanto de um possível trauma de guerra quanto da sua imaginação. Não é possível determinar com absoluta fidelidade a fonte, e, ao final, nesse caso, o mistério em nada interfere na potência da criação. A força de seu depoimento não está tanto na história original, mas na capacidade de atualizar os virtuais formados em torno dessa experiência original em outras condições de criação, que permitem atribuilhes novos sentidos completamente diferentes daqueles relacionados a tal experiência.

Assim, o feltro, que ele afirma também ter sido utilizado pelos tártaros para lhe salvar, ressurge com novos significados na mega escultura BRAZILIAN FOND (FOND V) (apresentada na XV Bienal Internacional de São Paulo, que dedicou uma sala exclusiva para o artista) e, principalmente, na aktion Coyote - I like America and America likes me. A escultura é composta por quatro enormes cilindros em formato de manta de feltro cobertos por placas de cobre. Sua imagem remete aos cilindros sagrados do budismo, mas a textura do feltro, ao mesmo tempo aconchegante e agressiva ao toque, produz sensações confusas para quem toca. Desejaria ele, aqui, relatar esteticamente sua sensação estando doente e envolto pelo feltro no gelo da Criméia ou estimular o público produzir suas próprias associações diante de algo que protege, mas isola do mundo exterior?

Em Coyote... , Beuys usa o feltro sobre si para isolá lo de todo contato físico com os Estados Unidos que não esteja previsto na estrutura da obra. Isso significa desembarcar do avião, vindo da Alemanha, já envolto pelo casulo de feltro (sem 
sequer por os pés em solo norte-americano), e ser encaminhado em uma ambulância sob uma maca até a René Block Gallery, em New York, para só ali, dentro do cercado que demarca o ambiente que ele dividirá por uma semana com um coyote selvagem, pisar no chão.

A aktion consiste exatamente em, durante esta semana de contato diante do público, o artista buscar interações com o animal e uma comunicação sutil que permita a co- existência de ambos. Para tanto, alguns materiais estão dispostos, entre estes, o cobertor de feltro com que Beuys chegou à galeria e 50 edições do periódico The Wall Street J ournal O cobertor foi destruído pelo coyote em uma das primeiras tentativas de interação, mas a experiência terminou com ambas as espécies vivas. Ao final da semana, tendo concluído a aktion, Beuys novamente se envolve em um cobertor de feltro, sobe na maca e, numa ambulância, é levado ao aeroporto Kennedy de volta à Alemanha sem estabelecer qualquer outro contato com a "América" além da vivência com o animal (a quem ele apelidou de "Little Joe") .

Essa experiência é apresentada por Beuys como uma tentativa de mergulho na América pré- colonizada, domínio dos animais selvagens e dos "pele-vermelhas". O artista buscou a experiência direta com os derradeiros habitantes desse mundo em desaparecimento, sem fábula, sem mediação de quaisquer outros elementos que não aqueles que contribuem para expressar a intencionalidade do discurso (a manipulação do The Wall Street J ournal, principal guia de economia dos Estados Unidos, adquire evidente sentido político nesse contexto). É o homem-artista J oseph Beuys que se coloca em devir coyote pelo agenciamento com o animal, 
numa relação estética, evidentemente, mas o mais protegida possível de agentes exteriores e outros materiais que não estejam relacionados com o processo.

Outra importante aktion que parte de imagens diretamente extraídas da memória de Beuys para recriar novos sentidos mediante a combinação com enunciadores específicos é Iphigenia/ Titus andronicus (apresentada na German Academy of Dramatic Arts, em Franfurt, entre 29 de maio e 7 de junho de 1969). Aqui, o artista divide a cena com um cavalo branco que descansa amarrado ao fundo da sala junto a um monte de feno. Em procedimento semelhante ao realizado com o coyote, Beuys irá propor, diante do público, uma série de tentativas de comunicação sonoras com animal, valendo-se tanto de instrumentos musicais quanto de sua própria voz microfonada, além de efeitos eletrônicos gravados. Entre os estímulos, está o texto shakespeareano Titus Andronicus e a Iphigenia de Goethe, que ele recita não interpretando as personagens, mas apenas lendo normalmente.

Os animais são outros símbolos- chave da linguagem do artista. Em sua aktion anterior, intitulada "Como se explica quadros a uma lebre morta" (Wie man dem toten Hasen die Bilder eklärt, levada a público em 1965, na Schemella Gallery, em Düsseldorf), Beuys, com a cabeça coberta de mel e com uma folha de ouro no topo, carregava no colo uma lebre morta por uma exposição, explicandolhe o sentido de cada obra.

Podemos dizer que esses símbolos extraídos da memória criadora, e que se repetem, são imagens especialmente potentes para elaboração do depoimento pessoal. Eles funcionam como um vocabulário particular que remete às vivências que resistiram ao fluxo criativo da memória, e, se ressurgem com intensidade, é 
porque deixaram impressões profundas na formação do artista. No caso das obras de Beuys, observamos claramente como as unidades mnemônicas do performer podem ser aplicadas diretamente à criação da cena (sem a mediação de narrativas ou de personagens pré formados, como sucede em seus processos) quando retirada do contexto histórico da experiência original e recombinada criativamente com outros materiais, produzindo uma ação mais complexa, cujos sentidos são mais abrangentes que aquela dramática.

No mesmo caminho, mas orientada por interesses artísticos distintos, aparece a produção da artista plástica e performer iugoslava Marina Abramovic. A obra de Abramovic pode ser dividida, para efeitos de análise, em dois períodos: quando a artista trabalhava com o namorado, o performer Ulay, e após a sua separação. Porém, notemos que as obras resultantes do trabalho com Ulay já trazem algumas das questões centrais para sua pesquisa, especialmente no que diz respeito ao tratamento e direcionamento da memória criadora, e que mais diretamente interessam a nossa tese, entre as quais figuram as dimensões do tempo e os estados alterados do corpo e da percepção.

Sua busca por experiências de limite, nesse sentido, fez com que o casal empreendesse verdadeiras temporadas de preparação psicofísica em locais específicos para cada performance. Assim, para a obra Nightsea Crossing (1984) foram necessários seis meses vivendo entre tribos aborígenes da Austrália, sob o calor médio de 50ำ, para se atingir o estado de auto-controle e suspensão que, conforme a artista, permite instaurar a permeabilidade sutil que marca a comunicação silenciosa entre artistas e público na performance. Como melhor explica o pesquisador Nick Kaye em seu artigo Ritualismo e Renovação - 
Reconsiderando a Imagem do Xamã154: "para Abramovic e Ulay, seguindo «sa experiência, é a função e o efeito do seu ato, mais do que a presença dos símbolos, o aspecto mais importante da peça".

Nightsea Crossing é composta por um mesmo ambiente que abriga performers e espectadores, estando estes separados daqueles por uma corda de veludo. Em frente às cadeiras para o público, Marina e Ulay estão elegantemente vestidos e sentados nos extremos de uma enorme mesa de jantar. No cenário, figuram alguns símbolos de nobreza como hastes de ouro, uma jarra de água gelada com folhas de ouro e o símbolo da suástica invertido bem no meio da parede central. Em suas posições, os performers não realizam ação alguma, mas constroem exatamente esse estado de consciência experimentado pelas vivências no deserto.

No mesmo caminho, A Casa com Vista para o Mar é um exercício de resultado estético bastante diferente de Nightsea Crossing (é uma performancesolo mais recente, quando sua parceria com Ulay já se esgotara), mas que dá continuidade a essa linha de investigação da artista. Na obra, Abramovic viveu por doze dias (de 15 a 26 de novembro de 2002) num ambiente projetado por ela própria para uma exposição diária de cerca de nove horas (a apresentação poderia ser vista pelo público diariamente das 9 h às 18h). O espaço era comporto por três módulos suspensos presos na parede ao fundo da galeria: à esquerda de quem vê, um módulo comporta um chuveiro e um vaso sanitário; no meio, outro com uma cadeira, uma mesa e um metrônomo, e à direita, uma cama de madeira sem

\footnotetext{
${ }^{154}$ Ritualism and Renewal-Reconsidering the Image of the Shaman, in Performance, p. 38. Tradução minha.
} 
colchão com um travesseiro de pedra e uma pia. Durante toda duração da performance, a artista permanecia em jejum.

Nesse trabalho, Abramovic questiona tanto os limites energéticos e expressivos do corpo, e suas dimensões não exploradas pelo homem quando restrito ao estado/comportamento cotidiano, quanto o papel da organização do tempo na programação e efetivação das atividades pela mente, que ela problematiza quando exige de si a exposição pública dos rituais mais pueris e orgânicos. Às suas palavras: "essa performance nasce de meu desejo de ver se é possível usar a simples disciplina diária, regras e restrições para me purificar. Posso transformar meu campo de energia? É possível para este campo de energia transformar o campo de energia do público e do espaço?’155

O desejo por uma possível comunicação energética é um dos fatores mais determinantes para caraterizar o depoimento pessoal de Abramovic. Embora em sua carreira, o leque temático de suas obras seja bastante amplo (para o Brasil, ela criou uma performance chamada Departure, baseada em imagens de garimpeiros com quem Abramovic trabalhou por cerca de três meses como preparação - em que a artista buscava um diálogo silencioso com um paredão de ametistas), nos debruçaremos sobre essa condição, bem como sobre sua oferta do corpo como fronteira última de interação, característica igualmente marcante de suas criações.

Abramovic se utiliza da dilatação do tempo para reconfigurar os padrões de funcionamento da mente, que, conforme a artista, organiza todas suas ações em funções de um modelo de tempo já assimilado no subconsciente. Quando propõe novas formas de simplesmente "existir" publicamente em um tempo reestruturado

\footnotetext{
${ }^{155}$ In A Casa com Vista para o Mar de Marina Abramovic - entrevista a Ana Bernstein. p. 132.
} 
pela criação em suas obras, o que pode parecer "inação" contém, de fato, todo um delicado e, às vezes, doloroso processo de estar-em-vida que nasce diante do espectador. Conforme ela relata:

\begin{abstract}
"O elemento tempo é muito importante para mim, porque eu programo minha mente para um certo tempo (...) Houve um momento muito difícil mentalmente, e outro muito difícil fisicamente. Fisicamente, foi extremamente difícil o dia em que a galeria ficou aberta das $9 \mathrm{~h}$ à meia-noite, o que significa 15horas. Muitas pessoas dormiram em galerias no passado, mas elas não tinham que interagir com o público. Eu digo que estou dormindo na galeria, mas, na verdade, eu nunca dormi."
\end{abstract}

A maneira como Abramovic constrói suas cenas-depoimento conduz a pesquisa sobre a memória para zonas verdadeiramente desconhecidas. Não que os outros processos até aqui analisados também não o façam, evidentemente o fazem quando promovem a atualização dos virtuais da memória em operações criadoras sob as condições específicas que caracterizam cada processo. Mas não é arriscado afirmarmos que Abramovic avança, nesse sentido, quando trabalha exatamente sobre os efeitos da re-sistematização do tempo nos rituais orgânicos que definem o funcionamento corporal, e induz seu organismo a outros estados de consciência e a agenciamentos que estabelecem novos níveis de percepção. A busca por um diálogo silencioso de energia com os materiais e com o público é questão recorrente em sua obra, e aponta quão cara é, para a artista, a necessidade de descobrir novas dimensões para o espectro sensorial e expressivo humano.

Essa procura, em suas criações, nem sempre se dá pela via do recolhimento e da auto-observação. Em certas obras, Abramovic propõe a ação violenta sobre o corpo como reflexão sobre seus limites, sobre a relação do sujeito com este e sobre as relações de poder inter-pessoais. Na performance Light/ Dark (1977), Ulay e a ${ }^{156}$ Op. cit., p. 135. 
artista se posicionavam um frente ao outro, nus, e se estapeavam violentamente no rosto por três horas. Premissa que chega realmente ao limite com Ritmo O.

Ritmo O é um trabalho solo de Marina em que a artista oferece 72 objetos diferentes para que o público utilize no seu corpo da maneira que desejar. Entre eles, está um machado, uma gilette, um chicote, uma arma, uma bala, álcool e fósforos. Ao propor jogos de interação tão arriscados e estruturar um depoimento pessoal que prescinde da auto-preservação, Abramovic radicaliza a busca por novos limites de existência para além das implicações orgânicas do corpo material. Sua atitude performativa parece dizer: "eu estou (ou quero estar) além disso, portanto, posso (podem) dispor desse estrato como quiser (em)."

O depoimento pessoal de Abramovic, pois, ilumina com novas questões o trabalho do performer. A memória criadora opera por um adensamento orgânico que se coloca permanentemente em condições de funcionamento instáveis para, a partir daí, encontrar, exatamente, novas formas de viver. Quando toma o trabalho sobre o tempo numa perspectiva de recriação e de experimentação, Abramovic mergulha em um campo profundamente instigante de investigação da memória criadora e das relações do ser com seus conteúdos em estados diferenciados de biofuncionamento. Seus relatos, nesse sentido, baseados em experiência tão singulares e radicais, acrescentam informações preciosas ao estudo de depoimento pessoal, e que só são acessíveis quando os artistas assumem o risco de se colocar no limite da vivência, e depois conseguem voltar para nos contar seus resultados.

O terceiro processo escolhido é o trabalho do performer Spalding Gray, cuja disposição do depoimento está entre as mais variadas e interessantes no quadro de produções da performance do século passado. Em suas obras, Gray experimentou 
as possibilidades expressivas que a construção e combinação de diferentes personas e personagens representando vozes distintas no desenvolver da ação podem revelar. Com isso, apontou formas inusitadas de projeção do depoimento do performer dentro do macro-depoimento pessoal que é a performance em si, e que permitem a multiplicação de sentidos na medida em que provocam as relações do artista com as alteridades criadas.

Sua obra é tão rica, nesse sentido, que nos obrigou a escolher certos processos em detrimento de outros, para que o volume de conteúdo a ser analisado não ficasse excessivamente pesado e dificultasse a análise de sua produção. Por tanto, selecionamos as performances Sakonnet Point, Rumstick Road e Nayatt School, levadas a público pelo Performance Group 157 na Performing Garage em New York em 1975. Esses trabalhos foram reunidos novamente em 1978, e reapresentados com o título Three Pieces in Rhode Island.

Os três títulos da peças foram retirados de lugares reais da infância de Gray, respectivamente, uma pequena cidade de veraneio, a rua da casa em que Gray viveu quando criança (66 Rumstick Road) e uma escola. Tal informação antecipa que estaremos diante de um mergulho, mais ou menos integral, do artista na história de seu passado, mas recontada pela nova lógica assumidamente criadora que determina a identidade de seu depoimento.

Sakonnet Point é dividida em seis seqüências: o avião, a criança, a casa, o leque, o cobertor e o lençol. É a única das três peças que não teve o cenário criado especialmente para sua apresentação. Sua disposição se vale de uma minuciosa

\footnotetext{
${ }^{157}$ Além de Gray e de Elizabeth Le Compte, idealizadores do projeto, o Performance Group era formado por Ron Vawter, Libby Howles, Bruce Porter, Bruce Rayvid e Gabrielle Lansner.
} 
coreografia de ações, gestos, objetos e sons (mas sem diálogos) no espaço para trazer impressões da infância de Gray sobre o mundo adulto na pretensa diversão que uma viagem de férias, a princípio, anuncia. Porém, essa ambientação, e todas as impressões de lazer que ela sugere, são tensionadas pela articulação de outros elementos, cujo efeito em cena evocam a violência e a incompreensão que uma criança pode sentir quando confrontada com certos aspectos dolorosos da realidade adulta (a ação do chicote de arame, a imagem da atriz babando leite, etc.)

O depoimento pessoal de Gray aparece mais diretamente em duas figuras, o próprio artista e um menino que tenta se enforcar no início da apresentação, e é supostamente "salvo" pelo artista adulto representando a si mesmo. As figuras femininas remetem à mãe de Gray (uma mulher que percorrre o espaço carregando uma casa de brinquedo, e depois toma um banho de papel picado como se estivesse num chuveiro - uma típica imagem da intimidade familiar: o filho que espia a mãe se lavar), vítima de sérios problemas mentais que a levaram ao suicídio, e cuja perda será o tema da segunda performance da trilogia.

Em Rumstick Road, Gray trata do delicadíssimo tema da morte da mãe, Betty Gray, ocorrida durante uma viagem do artista em 29 de julho de 1967. Para elaborar esteticamente essa perda, o performer se valeu de diversas fontes na composição de seu depoimento: entrevistas, carta, slides, etc. Outras vozes foram convocadas para comentar o acontecido: o pai de Gray, Alice Mason, uma velha vizinha da família, Dorothy Spadling Wood, avó de Gray, além de cartas da própria Beth falando de seu estado e de suas perspectivas.

Na maior parte da apresentação, Gray se expõe diretamente, mas se utiliza das outras vozes para compor seu discurso maior de incompreensão diante da 
tragédia pessoal. Ao final da performance, Gray atravessa o espaço e tira um telefone que está em cena do gancho. Reproduz o diálogo com o Dr. Henry Bradford, psiquiatra que cuidou de sua mãe antes do suicídio. O performer fala no presente, mas a voz do doutor é uma gravação que reproduz suas falas anteriores. É o artista brincando de contar sua história, representando a si mesmo, ou resgatando, de fato, uma experiência real?

Por fim, Nayatt School, uma performance profundamente irônica que usa a metáfora da escola indicada no título para representar um ambiente indefinido que denota ora uma instituição pública (com seus funcionários engravatados e entediados) ora uma escola mesmo, e ora, ainda, um palco aberto para a mediocridade humana (como a ação do dentista traído por sua mulher que se vinga no paciente). É a peça que mais explora as trocas de papéis e o trânsito entre o depoimento do performer e das personagens, promovendo um desfile de tipos que não são exatamente personagens dramáticos strictu sensu, mas tão pouco são os performers falando por si: há algum grau de mediação da fábula que se revela na utilização de adereços, figurinos e vozes específicas para cada figura.

O estudo das três peças de Rhode Island é suficiente para revelar um artista cuja experiência desdobrou a noção de depoimento pessoal. Gray se valeu do relato direto, da personagem, do depoimento de terceiros, da projeção de sua identidade histórica em outras figuras (o menino de Sakonnet Point), do depoimento gravado em diversos suportes, enfim, a lista é enorme. Pelas criações de Gray, a autenticidade do depoimento pessoal se legitima definitivamente não pelo compromisso com os conteúdos históricos, mas pela capacidade de recriação do vivido cujo produto é a cena-depoimento, a performance. O depoimento pessoal 
encontra, aqui, sua mais completa expressão como fruto da memória criadora, abandonando definitivamente qualquer resquício de um projeto de memória que pretendesserestituir integralmente uma experiência já vivida.

Entretanto, existe outra dimensão do depoimento pessoal, extra-artística, que introduz uma série de questões consistentes ao nosso debate e da qual não podemos nos esquivar. O vídeo-depoimento é uma forma de registro que surgiu no pós-guerra, e é produto de um período que o pesquisador Márcio Seligmann- Silva define como a época das catástrofes158 . Trata- se de um relato direto para a câmera de vítimas de crimes de estado, cujos conteúdos têm grande implicação histórica tanto para apuração dos fatos e possível condenação dos envolvidos, quanto para fortalecer os laços entre as vítimas, como se observou principalmente na comunidadejudaica.

Tal depoimento opera em uma delicada chave de lembrança e criação. Se, por um lado, a recuperação mais fiel possível da experiência original é urgente, por outro, não é possível suprimir a natureza criativa da ação mnemônica que exatamente qualifica o vídeo-depoimento como fronteiriço à arte, ainda que a criação, aqui, não seja assumida, nem de fato, desejada. Todo testemunho contém a criação, e carrega em si a possibilidade do "engano": “(...) 'o testemunho tem sempre parte com a possibilidade ao menos da ficção, do perjúrio e da mentira', afirma Derrida. Eliminada essa possibilidade, nenhum testemunho seria possível e, de todo modo, não terá mais sentido do testemunho"159.

\footnotetext{
${ }^{158}$ Memória, História, Literatura - O testemunho na era das catástrofes, p. 377

${ }^{159}$ Op. cit., p. 378.
} 
A memória criadora enfrenta, na problemática rigorosa imposta pelo vídeodepoimento, suas limitações ontológicas mais contundentes, para as quais a arte não oferece solução. Resta, talvez, aceitar que, ao assumirmos a memória como recriação do vivido, possamos encontrar o caminho mais eficiente para tentar extrair os aspectos fantasiosos dos relatos, quando necessário, como nessa caso. 


\section{CONCLUSÃo}

Nossa pesquisa iniciou-se por uma intuição oriunda da prática, e por tal caminho desejaríamos conclứla. Os casos analisados na última parte da tese, ainda que emblemáticos no que diz respeito às singularidades na elaboração do depoimento, são exemplos extraídos arbitrariamente para fins de estudo de um mapa de diversidades que a cada dia surpreende a cena pós-moderna com novas manifestações. Interessaria-nos muito que nossa análise e as bases teóricas aqui desenvolvidas avançassem e atingissem a produção de outros criadores, já que essa prática é a fonte que alimenta todo legítimo estudo das artes performativas, e para onde a nossa própria prática deve, se tivermos sucesso, confluir.

Pretendemos ter apresentado uma reflexão sobre a memória que permita um novo olhar sob suas atribuições, e que por meio deste, se reterritorializem todas as demais funções. Desejamos que nossa perspectiva sobre a cooperação global dos atributos do ser para a criação traga alguma luz à complexidade das operações humanas em estado de criação. De fato, o que defendemos com nossa apologia da memória criadora é que o ser humano se movimenta de forma naturalmente criativa para a resolução de suas questões, e a memória é a capacidade de combinar o vivido de antes com a vivência de agora, que, efêmera, já é vivido.

Tal caminho para o entendimento dos processos da mente nos parece irreversível no quadro de referência contemporâneo. A velocidade das relações na pós-modernidade leva ao limite a antiga noção de tempo como sucessão apenas. Precipitaram-se alguns pensadores quando consideraram que tal velocidade 
decretaria o fim da história como a conhecemos, mas não exageraram quando exigiram do filósofo atual uma revisão profunda dos termos de apreensão e organização dessa mesma história à luz das multiplicidades e simultaneidades que sempre incidiram sobre os deslocamentos energéticos dos processos vivos, e que agora não podem mais ser ignoradas mesmo nas atividades mais simples do cotidiano.

O artista performativo sempre esteve mais próximo que qualquer outro do tempo não cronológico. Se é possível se encontrar uma medida libertadora do tempo na experiência, então a experiência pós-moderna deve estar alerta para o trânsito entre o visível e o invisível, pois o presente já é memória no exato momento de sua manifestação. O depoimento é a assunção consciente dos conteúdos-formas do discurso artístico, ao qual todo artista maduro não se furta de atender.

Admitir a memória como recriação do vivido não deve sugerir uma complacência irresponsável com a apuração dos fatos históricos, mas exatamente o oposto. Admitindo-se que sua natureza está intrinsicamente ligada à imaginação, ou antes, que a própria memória trabalha com a recriação e não com a reprodução da percepção (para o que Aristóteles nos já nos alertava há dois milênios passados), é possível abordar o testemunho em sua instância volátil, fluida, que não permite trazer de volta o passado, mas que pode (e em alguns casos, como já vimos, deve) encontrar suas maneiras de recriar mimeticamente as experiências.

Falar de memória como fluxo é tirar o sujeito de sua posição de essência, legitimada por todo pensamento antigo até a modernidade. Essa mudança não é confortável, mas é irreversível: não somos uma entidade em processo, somos o 
próprio processo, estratos múltiplos e multidimensionais em devir dançando na cartografia energética do universo. A memória é a pequena parte de consciência sobre os adensamentos que nos definem que resiste a essa dança, e permite com que nos reconheçamos, ainda e fugazmente, como "nós".

O depoimento pessoal é maneira particular que o homem encontrou para brincar com a dança da memória e direcionar a construção dos estratos. Usando a personagem, multiplicando-se em alteridades por vezes antagônicas, mergulhando nas forças do imaginário coletivo, não importa qual seja o modelo de estimulação e pressão, ele é em si uma criação artificial, e aí está a brincadeira.

Se a vida nos oferece naturalmente as forças que direcionam e qualificam as vivências, pela sua apreensão formamos a memória e por meio dela nos subjetivamos, então o depoimento pessoal é a maneira como forjamos artifícios circunstancias para nos reinventarmos pela arte, para transbondarmos as forças cotidianas de delimitação do vivido e encontrarmos novos "álibis" para expressão no caldeirão das fições. Somos memória, ou melhor, a memória é a arte que permite com que nos reconheçamos. Mas somos igualmente criação de nós mesmos quando desejamos recordar algo que passou e ao qual estamos apegados porque é uma marca que nos identifica.

Somos, enfim, a tentativa de adensamento perene, o esforço de resistência ao inefável movimento do plano, que sucumbe, e nessa submissão se ultrapassa e sobrevive. Como criação e como criador, criativamente. 


\section{BIBLIOGRAFIA}

$\underline{\text { Livros }}$

ADRIANI, G.; MESSER, T. M. J oseph Beuys: Drawings, Objects anda Prints. Stuttgart: Institute for Foreign Cultural Relations, 1989.

AGOSTINHO, Santo, Bispo de Hipona. Confissões. São Paulo: Paulus, 1984.

ALLIEZ, Éric. Deleuze Filosofia Virtual. São Paulo: editora 34, 1996.

ARISTÓTELES. De Anima. trad. Maria Cecília Gomes dos Reis. São Paulo: Ed. 34, 2006.

Poética. Série Os Pensadores. São Paulo: Nova Cultural, 1999.

ARTAUD, Antonin. O Teatro e seu Duplo. São Paulo: Martins Fontes, 1993.

BARBA, Eugenio. A canoa de papel tratado de Antropologia Teatral. Campinas: Hucitec, 1991.

, SAVARESE, Nicola. A Arte Secreta do Ator Dicionário deAntropologia Teatral. Campinas: Hucitec, 1995.

BERGSON, Henri. Matéria e Memória. São Paulo: Martins Fontes: 2006.

. Memória e Vida. São Paulo: Martins Fonte, 2006.

BERNIS, J eanne. A Imaginação Do sensualismo epicurista à psicanálise. Rio de J aneiro: J orge Zahar Editor, 1987.

BIRRINGER, J ohannes. Performance on the edge. NewYork: Continuum, 1999.

BUNDY, Murray Wright. The Theory of Imagination in Classical and Mediaeval Thought. Illinois: Folcroft Library Editions, 1970.

CARLSON, Marvin. Performance a critical introduction. New York: Routledge, 2004.

CARUTH, Cathy. Unclaimed experience. Trauma, Narrative and History. Baltimore/ Londres: J ohn Hopkins University Press, 1996.

COHEN, Renato. Performance como linguagem. São Paulo: Perspectiva, 2002. . Work in progress na cena contemporânea. São Paulo: Perspectiva, 1998. 
DAMASIO, Antonio. O erro de Descartes: emoção, razão e cérebro humano. São Paulo: Companhia das letras, 1996.

DELEUZE, Gilles. Empirismo e Subjetividade. São Paulo: editora 34, 2001. . Foucault. Brasília: Editora Brasiliense, 1988. e GUATTARI, Felix. Mil Platôs Capitalismo e Esquizofrenia. vol 1. São Paulo: editora 34, 1995. . Mil Platôs Capitalismo e Esquizofrenia. vol. 2. São Paulo: editora 34, 1995. . Mil Platôs Capitalismo e Esquizofrenia. vol 3. São Paulo: editora 34, 1996. . Mil Platôs Capitalismo e Esquizofrenia. vol. 4. São Paulo: editora 34, 1997. . O que é Filosofia?. São Paulo: editora 34, 1992.

DESCARTES, René. Discurso sobre o Método . São Paulo, Hemus, (data de impressão não apontada).

. Meditaciones Metafísicas com objeciones y respuestas. Madrid: Ediciones Ālfaguara, 1977.

DURAND, Gilbert. A Imaginação Simbólica. São Paulo: Cultrix/Edusp, 1988.

FREUD, Sigmund. Obras Completas. Rio de J aneiro: Imago, 1976.

GADAMER, Hans-Georg. (trad. Flávio Paulo Meurer e revisão da tradução Enio Paulo Giachini). Verdade e Método I: traços fundamentais de uma hermenêutica filosófica. Petrópolis: Editora Vozes, 2005.

GALIZIA, Luiz Roberto. Os Processo Criativos de Robert Wilson: Trabalhos de Arte Total para o Teatro Contemporâneo. São Paulo: Perspectiva, 1986.

GOLDBERG, Rose Lee. Performance: Live Art from 1909 to present. Londres: Cox and Wylman, 1979.

GROTOWSKI, J erzy. Em Busca de um Teatro Pobre. Rio de J aneiro: Civilização Brasileira, 1992.

. O Teatro Laboratório de J erzy Grotowski 1959-1969. São Paulo:Perspectiva, 2007.

HENRI, Adrian. Total Art: Environments, Happenings and Performance. Londres: Thames and Hudson, 1974. 
HIRVELA, David P.. The Performing Arts: an audience's perspective. Dubuque: Iowa State University, 1990.

HUME, David. Investigação acerca do entendimento humano. São Paulo: Companhia Editora Nacional, 1972.

INSTITUT FÜR AUSLANDSBIEZENHUNGEN. J oseph Beuys - drawings, objects and prints. Stuttgart: Institute for Foreign Cultural Relations, 1989.

IZQUIERDO, Ivan. A arte de esquecer. Cérebro, Memória e Esquecimento. Rio de J aneiro: Vieira e Lent, 2005. . Memória. Porto Alegre: Artmed, 2002. .Silêncio, por favor. São Leopoldo: Editora Unisinos, 2003.

KOLB, Bryan; WHISHAW, Ian Q. Neurociência do Comportamento. Barueri: Manole, 2002.

LENT, R. Cem Bilhões de Neurônios. Rio de Janeiro: Atheneu, 2004.

LÉVY, Pierrre. O que éo virtual?. São Paulo: editora 34, 1996.

LYOTARD, J ean-François. A condição pós-moderna. Lisboa: Gradiva, 1989. (trad. Ricardo Correa Barbosa). O pós- moderno. Rio de Janeiro: J osé Olímpio, 1993.

LYRA, Bernardete; GARCIA, Wilton (org.). Corpo e Cultura. São Paulo: ECA/USP, 2001.

PARENTE, André. Imagem Máquina. São Paulo: editora 34, 1993.

PINKER, Steven. Como a Mente Funciona. São Paulo: Companhia das Letras, 1997.

PLATÃO. (trad. Carlos Alberto Nunes). Diálogos. Curitiba: Universidade Federal do Paraná, 1974. . (trad. J orge Paleikat e J oão Cruz e Souza). Diálogos. Rio de Janeiro, 1973. . A República. (trad. J acó Guisbourg). São Paulo: Difusão Européia do Livro, 1965.

READ, Herbert. A Arte de Agora. São Paulo: Perspectiva, 1991. 
RICHARDS, Thomas. At Work with Grotowski on Physical Actions. New York: Routledge, 1995.

SARLO, Beatriz. Tempo Passado - cultura da memória e guinada subjetiva. São Paulo: companhia das Letras, 2007.

SARTRE, J ean-Paul. O Existencialismo é um Humanismo; A Imaginação; Questão de Método. Série Os Pensadores. São Paulo: Nova Cultural, 1987.

SCOTT, Dominic. Plato’s Meno. Cambridge: Cambridge University Press, 1995. 2006.

. Recollection and Experience. Cambridge: Cambridge University Press,

SARTRE, J ean- Paul. O Existencialismo é um Humanismo. Série Os Pensadores. São Paulo: Nova Cultural, 1987.

. A Imaginação. Série Os Pensadores. São Paulo: Nova Cultural, 1987.

. Questão de Método. Série Os Pensadores. São Paulo: Nova Cultural, 1987.

SCHECHNER, Richard. The End of Humanism. NewYork: Laj, 1982.

eAPPEL, Willa. By means of Performance Intercultural studies of theatre and ritual. Cambridge: Cambridge University Press, 1990.

SELIGMANN SILVA, Marcio; NESTROVSKI, Arthur (orgs). Catástrofe e Representação. São Paulo: Escuta, 2000.

(org.). História, Memória, literatura. O testemunho na era das catástrofes. Campinas: Unicamp, 2003.

.O local da diferença. Ensaios sobre memória, arte, literatura e tradução. São Paulo: Ed. 34, 2005.

STANISLAVSKI, Constantin. El trabajo del actor sobre si mismo. Buenos Aires: Editorial Quetzal, 1980.

.El trabajo del actor sobre su papel. Buenos Aires: Editorial Quetzal, 1977.

SORABJ I, Richard. Aristotle on Memory. Londres: Duckworth, 1972.

TEMKINE, Raymond. Grotowski. Lausanne: L'Age d'Homme, 1970.

TURNER, Victor. The Anthropology of Performance. New York: PAJ , 1992. 
WATSON, Ian. Towards a Third Theatre Eugenio Barba and the Odin Teatret. New York: Routledge, 1995.

YATES, Frances. The Art of Memory. Londres: Pinlico, 1992..

Artigos (Revistas, Catálogos e Jornais)

ABAMOVIC, Marina. Aventuras pelo invisível. Folha de São Paulo, Suplemento Mais!. São Paulo, 17 ago.2003.

. A Casa com Vista para o Mar de Marina Abramovic. Entrevista a Ana Bērnstein. Sala Preta, São Paulo, n. 3, pp. 132-140, 2003.

BIRMAM, J oel; CHUEIRI, Vera Karam de; DERRIDA, J acques; DUQUEESTRADA, Paulo César; FAUSTINO Sílvia; GUATELLI, Igor; PERRONEMOISÉS, Cláudia; PERRONE-MOISÉS, Leyla; SAFATLE, Vladimir. Dossiê Derrida. Revista Cult. São Paulo, n. 117, pp. 40-64, ago.- 2007.

BIERMAN, J ames. Three Places in Rhode Island. Drama Review, n. 1 (T81), vol. 23, pp. 13-30, New York, mar. - 1979.

BROOK, Peter. Grotowski, el arte como vehículo. El Tonto del Pueblo, La Paz, n. 3-4, pp. 152-153, mai.- 1999.

CARLSON, Marvin. Performing the self. Modern Drama, n. 4, vol. 39, pp. 599607, 1996.

CARRERI, Roberta. El viaje del actor, del training al espetaculo. Máscara,

Ciudad del México, n. 12, pp. 42-45, jul.- 1993.

DANION, J . M.; MELEUMANS, T.; KAUFFMANN- MÜLLER, F.; VERMAAT, H..

Intact implicit learning in schizophrenia. American J ournal of

Psychiatry, 158, pp 944-948, 2001.

DAVVETAS, Demosthenes. Departure - The Brazilian Project of Marina Abramovic. Performance, n. 65-66, pp. 61-65, 1992.

FÉRAL, J osette. Performanceand Theatricality: The Subject Demystified.

Modern Drama. New York, v. 25, n. 1,p. 170-181. mar. 1982. 
GRAY, Spalding. About Three Places in Rhode Island. Drama Review, n. 1 (T81), vol. 23, pp. 31-42, New York, mar. - 1979.

GROTOWSKI, J erzy. el Performer. El Tonto del Pueblo, La Paz, n. 3-4, pp.154 155, mai.- 1999.

. De la compañia teatral a El arte como vehículo. El Tonto de Pueblo. La Paz, n. 3-4, pp. 156-164, mai.-1999.

KAYE, Nick. Ritualism and Renewal - Reconsidering the I mage of the Shaman. Performance, n. 59, pp. 31-44, 1989/ 1990.

KURTEN, Martin. La terminologia de Stanislavski. Máscara, Ciudad del México, n. 15 pp. 34-37, out.- 1993.

LIMA, Tatiana Motta. A Arte como Veículo. Revista do Lume, Campinas, n. 2, pp. 77-88 ago.- 1999.

MÁSCARA - NÚMERO ESPECIAL DE HOMENAJ E A GROTOWSKI. Ciudad del México, Escenología, 1993.

MENNEM, Richard. Grotowski's Paratheatrical Projects. The Drama Review, NewYork, v. 4, n. 19, pp. 60-69, 1975.

OSINSKI, Zbigniew. “Grotowski's Blazes the Trails - from Objective Drama to Ritual Arts". The Drama Review, New York, v. 1, n. 35, pp. 95-111, 1991.

PAVIS, Patrice. Performance - Notes Towards a Semiotic Analysis. The Drama Review, New York, s.d., pp. 93-104.

RASMUSSEN, Iben Nagel. As Mudas do Passado. Revista do Lume, Campinas, n. 2, pp. 17-30, 1999. 
